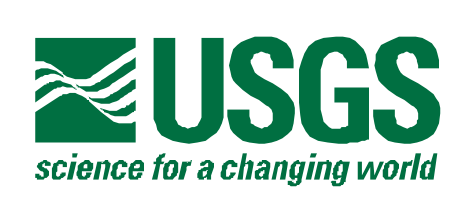

\title{
FOURTH INTERNATIONAL CIRCUMPOLAR ARCTIC VEGETATION MAPPING WORKSHOP
}

By M.K. Raynolds and C.J. Markon

Open-File Report 02-181

Any use of trade, product, or firm names is for descriptive purposes only and does not imply endorsement by the U.S. Government.

U.S. Department of the Interior

U.S. Geological Survey 


\title{
Fourth International Circumpolar Arctic Vegetation Mapping Workshop
}

\author{
Edited by M.K. Raynolds'and C.J. Markon $\left.\right|^{2}$
}

A compilation of short papers, abstracts, and comments presented at the Russian Academy of Sciences
Moscow, Russia

April 10-13, 2001

1 Alaska Geobotany Center, Institute of Arctic Biology, University of Alaska, Fairbanks, Fairbanks, AK, 99775

2 U.S Geological Survey, Raytheon STX Corp., 4230 University Drive, Anchorage, AK, 99508-4664, Contract Number 1434-CR-N97-CN-40274 


\section{TABLE OF CONTENTS}

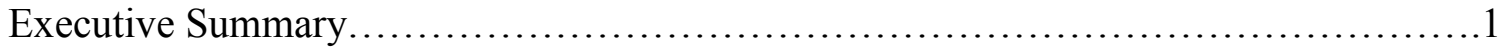

Future directions for the CAVM Project - D.A. Walker............................ 4

Canadian Arctic vegetation and ecosystem properties - W.A. Gould, M.K. Raynolds, and D.A.Walker............................................................. 6 Synthesis of Alaskan and Canadian Portions of the CAVM Map - M.K. Raynolds, D.A. Walker, W.A. Gould, and C.J. Markon.........................................13 On the way to an integrated vegetation map of Greenland - Fred J.A. Daniels and Maike

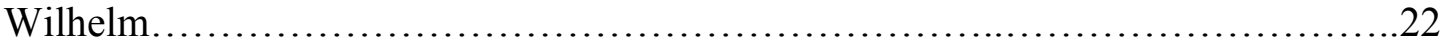

The position of Iceland in the system used in the CAVM mapping - Eythor Einarsson .35

Percentage lake cover in the Russian Arctic - Galina V. Ananjeva (Malkova) and Olga. E. Ponomarjeva.............................................................40

Landscape map of the Russian Arctic - Dmitriy S. Drozdov, Galina V. Ananjeva (Malkova), and Yuri V. Korostelev ................................................43

Vegetation map of European Russia - Sergei S. Kholod and Galina V. Ananjeva.........46

Vegetation map of West Siberia, Taimyr, and Yakutia - Natalia G. Moskalenko.........49

Some comments on the mapping of circumpolar arctic vegetation -

Boris A. Yurtsev..............................................................57

Higher syntaxa from the Russian arctic - Fred J.A. Daniels.............................60

Principles of design for a map (legend, color, hachure) - Irina N. Safronova..............63

Plans for publication of the CAVM map - Stephen S. Talbot............................66

A draft circumarctic vegetation map of the Norwegian Arctic - Arve Elvebakk.........68

A hierarchical approach to mapping southwest arctic Alaska - Carl J. Markon and

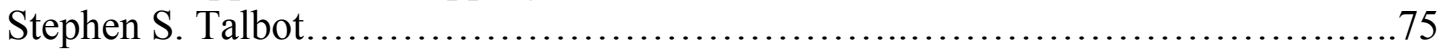

Appendix A - Zonal Discussion

Response to Elvebakk's proposal for zonal subdivision of the Arctic: Why the current Russian concept of 'polar desert' is inappropriate for North America, May 24, 2000 -

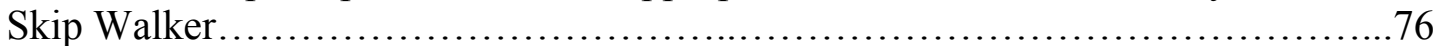

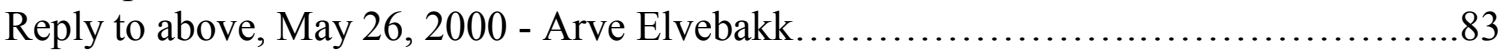

Reply to above, May 26, 2000 - Skip Walker....................................... 86

Reply to above, May 29, 2000 - Arve Elvebakk..................................... 87

Zonation, June 23, 2000 - Boris Yurtsev........................................... 88

Reply to Arve Elvebakk response, July 12, 2001 - Boris Yurtsev.......................89

Reply to Arve Elvebakk response, July 25, 2001 - Boris Yurtsev.......................90

Reply to Steven Talbot, April 18, 2001 - Boris Yurtsev................................92

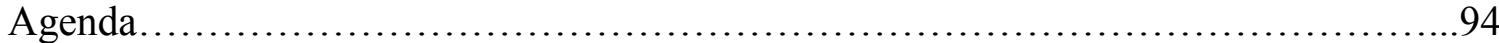

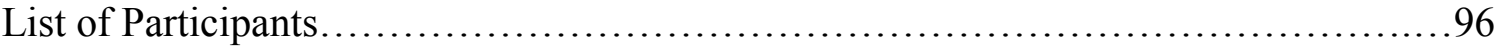




\section{EXECUTIVE SUMMARY}

During the week of April 10, 2001, the Fourth International Circumpolar Arctic Vegetation Mapping Workshop was held in Moscow, Russia. The purpose of this meeting was to bring together the vegetation scientists working on the Circumpolar Arctic Vegetation Map (CAVM) to (1) review the progress of current mapping activities, (2) discuss and agree upon a standard set of arctic tundra subzones, (3) plan for the production and dissemination of a draft map, and (4) begin work on a legend for the final map.

\section{Zone Discussions}

It was decided that the CAVM would use five subzones of the Arctic Tundra Zone following the Panarctic Flora Initiative decision to use the subzones as mapped by Boris Yurtsev. The exact location of the boundaries can be adjusted to reflect knowledge based on ground data. Where ground knowledge is limited, the zones will be used to predict vegetation characteristics by extrapolating from other areas within that zone.

As a result of the decision to use five subzones, parts of the Russian maps will have to be revised, changing their zones 2 and 3 to the new zones 2, 3, and 4. Canada, Alaska, and Greenland were mapped using five subzones, although the exact locations of these boundaries may still be adjusted on the basis of discussion and photographs of the Russian arctic.

\section{First Draft Map}

The group unanimously supported the production of a single map sheet by the end of 2001. This double-sided sheet would be approximately $100 \times 130 \mathrm{~cm}$ and include a vegetation physiognomy map at a 1:7,500,000 scale, as well as ancillary and derived maps at a smaller scale. This map would show generalized vegetation information suitable for modelers and others. Stephen Talbot (U.S. Fish and Wildlife Service) will apply for funding to produce the map through the U.S. Fish and Wildlife Service as a Circumpolar Arctic Flora and Fauna (CAFF) technical report. The map production schedule is described below.

The legend for this map will be based on plant functional types. During the workshop, tables of plant functional types occurring in each area of the map were created. Canada, Alaska, and Greenland were combined into one table. All Russian tables will be combined once the changes from four to five subzones have been made and sent to Skip Walker, who will combine them with the existing tables for North America. Bill Gould, Natalia Moskalenko, Skip Walker, and Fred Daniels will develop the legend for the map from the combined plant functional type table (table 1).

Table 1. Plant functional types used for the CAVM project

\section{SUBZONE}

\begin{tabular}{|l|l|l|l|l|l|}
\hline & Acidic & Nonacidic & $\begin{array}{l}\text { Strongly } \\
\text { Carbonate }\end{array}$ & Saline & Notes \\
\hline Dry & & & & & \\
\hline Moist & & & & & \\
\hline Wet & & & & & \\
\hline Riparian & & & & & \\
\hline
\end{tabular}

Plant functional type abbreviations:

$\begin{array}{llll}\mathrm{t} & \text { tree } & \text { ps } & \text { prostrate dwarf shrub } \\ \text { tls } & \text { tall shrub } & \mathrm{g} & \text { grass } \\ \text { ls } & \text { low shrub } & \text { ts } & \text { tussock sedge } \\ \text { es } & \text { erect dwarf shrub } & \text { os } & \text { other sedge } \\ \text { hs } & \text { hemiprostrate dwarf shrub } & \text { r } & \text { rush }\end{array}$




$\begin{array}{llll}\mathrm{f} & \text { forb } & \text { om } & \text { other moss } \\ \mathrm{rl} & \text { reindeer lichen } & \mathrm{c} & \text { cyanobacteria } \\ \mathrm{ol} & \text { other lichen } & \mathrm{b} & \text { barren } \\ \mathrm{sm} & \text { sphagnum moss } & & \end{array}$

\section{Rules for Determining Plant Functional Types:}

(1) Cross out any boxes in the table that do not occur in large enough areas to map.

(2) Describe a community's plant functional types only if that community is dominant within polygons. It may be necessary to include more than one community in a box, if their plant functional types are different and are dominant in polygons.

(3) Only list a plant functional type if it includes over 25 percent of the cover of vegetated areas within a polygon.

(4) Include only up to five plant functional types in one description.

(5) Underline the most important plant functional types.

(6) Circle the box that represents the characteristic zonal vegetation (placor).

\section{Legend for the Final Map}

Drafts of the legend for the final map will be prepared using three different approaches. Irina Safronova and other Russian mappers will prepare a legend following the Russian approach of detailed community descriptions. Fred Daniels, Arve Elvebakk, and Nadya Matveyeva will work on a legend based on Braun-Blanquet classification. Skip Walker and Bill Gould will work on a legend based on a structural approach. These legends will include a color scheme and text labels and descriptions but will not be complete for the entire map. A meeting will be held in St. Petersburg in late February or early March of 2002 to compare these legend approaches and decide on a legend for the final map.

\section{Map Production Schedule}

May 15 -

May 15 -

June 15 -

June 30 -

August 31 -

August 31 -

September 15 -

September 30 -

October 31 -

October 31 -

November 15 -

November 30 -

December 15 -

December 31 -

July 15, 2002 -
Abstracts sent to Fairbanks for compilation in USGS Open-File Report.

Greenland polygons finalized and sent to Fairbanks

Russian subzones changed from four to five. Corresponding changes to map polygons, legend, lookup table, and plant functional type table sent to Fairbanks

Greenland map combined with Alaskan and Canadian map

Russian maps combined with North American maps

Legend for physiognomic map finalized

Grant proposal to U.S. Fish \& Wildlife Service

First draft of physiognomic map

Review of physiognomic map complete

First draft of ancillary and derived maps

Final draft of physiognomic map

Review of ancillary and derived maps complete

Final draft of ancillary and derived maps

All maps, legends, summary tables ready for publication

Final publication

\section{Summary Schedule by Country of Tasks to be Accomplished, with All Tasks Completed by}

August 31, 2001

Iceland:

Copy of zonal boundary to Fairbanks by July 15

Map polygons and attributes to Fairbanks by August 15 
Community list and lookup tables to Fairbanks by August 31

Svalbard: $\quad$ Map polygons and attributes to Fairbanks by August 15

Community list and lookup tables to Fairbanks by August 31

Greenland: $\quad$ Coverage with final polygons to Fairbanks by May 31

Community list and lookup table to Fairbanks by July 31

Alaska: $\quad$ All revisions to polygons and their attributes by May 31

Create and combine tables by June 15

Canada: $\quad$ Any revisions to polygons and their attributes by June 30

Update of tables by August 31

Russia: $\quad$ Revise from four subzones to five subzones by June 15

Update coverage's to reflect five subzones, include lake polygons,

add any other attributes by June 30

Any revisions to polygons and attributes by August 15

Community lists and lookup tables to Fairbanks by August 31 


\title{
FUTURE DIRECTIONS FOR THE CAVM PROJECT
}

\author{
D.A. Walker \\ Institute of Arctic Biology \\ University of Alaska Fairbanks \\ Fairbanks, AK 99775, USA \\ E-mail: ffdaw@uaf.edu
}

One of our goals at this meeting is to decide the nature of the initial product, plot a course for development of the complete synthesis, and plan for a draft of the CAVM to be complete by the end of 2001. I anticipate that this will take several forms and will lead in new directions as we begin to see the possibilities of the database we are creating. I would like to consider three products that we should be able to accomplish fairly soon once the draft maps are available: (1) a single map sheet, (2) a book with a complete synthesis of the product, and (3) a Web- and GIS-based arctic geobotanical atlas.

\section{Initial product: Single map sheet of the CAVM}

Rapid publication of the CAVM is highly desirable to meet funding requirements and to fulfill the needs of modelers and other circumpolar scientists who are anticipating the map. A simple map will satisfy most of the modelers' needs and would be a great improvement over existing maps. This would be a synthesis of the North America and Eurasia sections. It would be produced at 1:7,500,000 scale, with inset maps at smaller scales, possibly about 1:20,000,000. The anticipated size of the map would be about 130 $\mathrm{cm} \times 100 \mathrm{~cm}$ with color maps on both sides of the map sheet. The front side of the map would have the large vegetation map, showing the physiognomy of the vegetation complexes. Inset maps would include (1) the AVHRR base image, (2) topography, (3) bioclimatic subzones, (3) floristic subprovinces, (4) maximum NDVI, (5) percentage of open water, (6) dominant plant functional types, (7) horizontal structure, (8) above ground and below ground biomass, and (9) annual primary production. Summary tables may be included on the map sheet for the entire circumpolar area and broken down by subzones, or floristic provinces, or countries. This will most likely be a map that portrays the major vegetation units (physiognomic categories) with little detail regarding the plant communities. A legend for this map may be developed at this meeting using the Canadian and North American maps as examples. Details can be worked out in the coming months. Martha Raynolds will be responsible for coordinating this effort, which will require the close collaboration of all the CAVM participants. Steve Talbot will lead a discussion regarding the possibility of the U.S. Fish and Wildlife Service publishing the map, and I would like to set a goal for a draft map by early winter 2001, with publication in early 2002 .

\section{Future product: A book}

A book, providing a comprehensive treatment of the arctic vegetation using the CAVM as a framework, may be developed in the future. Initial chapters could be presented at upcoming international meetings, such as the International Association of Vegetation Science or the International Permafrost Conference. This book would include an overview of the CAVM, the methods of its construction, a description of circumpolar products, and chapters about the various mapped sectors. All the sectors would use common terminology and map legends to provide a unified nomenclature for describing the arctic plant communities. Discussions would use the subzones, floristic provinces, parent material types, and mesotopographic gradient as a framework and would include photographs. There would be a synthesis of the entire circumpolar region centered on the 1: 7,500,000-scale maps produced for the single map sheet. Plant-community-level detail would not be shown on the circumpolar map but would be in the database and be used for maps at finer scale in the chapters of the various sectors of the Arctic. I would like to see a more detailed outline soon so that we could approach publishers for consideration of this product. A simple outline for the book follows:

Title: Circumpolar Arctic Vegetation: Based on a 1:7,500,000-Scale Map

Editors: D.A. Walker and the CAVM editorial board

\section{Chapter 1. Overview: Skip Walker}


History of the CAVM project, definition of the Arctic and rationale for the southern boundary, framework for the CAVM and subsequent chapters, bioclimatic subzones, floristic sectors, parent material, mesotopographic transects, method for making the CAVM

Chapter 2. A Braun Blanquet framework for classification of arctic plant communities: Fred Daniels, Arve Elvebakk, Nadya Matveyeva

Chapter 3. Floristic nomenclature for the CAVM: Boris Yurtsev, Dave Murray

Chapter 4. The circumpolar arctic: Skip Walker, Martha Raynolds, Natalia Moskalenko

Examples of the baseline information used: false-color AVHRR CIR image, topography, NDVI map, derived maps portraying physiognomy, dominant plant functional types, biomass, production, percentage of water, areas of various parent material types, surficial geology, bedrock geology, soils

Chapter 5. Alaska: Skip Walker, Martha Raynolds, Carl Markon, Steve Talbot (Arctic Slope, Seward Peninsula, Yukon-Kuskokwim River Delta)

Chapter 6. Canada: Bill Gould, Martha Raynolds, Sylvia Edlund (with focus on the Canadian Transect)

Chapter 7. Greenland: Fred Daniels, Maike Wilhelm

Chapter 8. Svalbard: Arve Elvebakk

Chapter 9. Iceland: Eythór Einarsson

Chapter 10. Russia:

European Russia: Sergei Kholod

West Siberia: Natalya Moskalenko

Taimyr Peninsula: Nadya Matveyeva

Yakutia: Raisa Shelkunova

Chukotka: Adek, Boris Yurtsev

\section{Chapter 11. Conclusions}

\section{A Web-Based Circumpolar Arctic Geobotanical Atlas}

The U.S. arctic science community is rapidly embracing the GIS as a tool for research and information. The National Science Foundation recently sponsored an Arctic GIS workshop in Seattle, Wash., as an initial move toward organizing GIS, remote sensing, and geospatial data efforts across the Arctic. Webbased information systems are a key aspect of the move toward having a circumpolar network of sites sharing information. We have developed a preliminary prototype, which is essentially a collection of maps that have been made during the course of many years of research. Most of the maps were produced in conjunction with three projects: (a) the CAVM, (b) the geobotanical atlas of the Kuparuk River basin in northern Alaska, and (c) the geobotanical atlas of the Prudhoe Bay region. The Atlas has a four-

dimensional structure that allows the user to obtain data in various ways. The talk will demonstrate some of the initial information in the atlas as a starting point and as encouragement for the CAVM to consider moving toward a Web-based atlas that could involve other circumpolar mapping efforts, such as the circumpolar permafrost and soils maps. 


\title{
CANADIAN ARCTIC VEGETATION AND ECOSYSTEM PROPERTIES
}

\author{
W.A. Gould \\ International Institute for Tropical Forestry, \\ PO Box 25000, Rio Piedras, \\ Puerto Rico, 00928-5000 \\ E-mail: IITF_COOP@upr.edu \\ M.K. Raynolds and D.A. Walker \\ IAB, University of Alaska, \\ 311 Irving I, PO Box 757000, \\ Fairbanks, AK 99775-7000, USA \\ E-mail: fnmkr@uaf.edu,ffdaw@uaf.edu
}

The Canadian Arctic Vegetation Map is being prepared as a component of the Circumpolar Arctic Vegetation Mapping project (CAVM). The CAVM is an effort by an international group of scientists to create a map that will be useful in monitoring and modeling vegetation change on a global scale. The circumpolar map has the following characteristics:

(1) It is a composite of regional maps being developed by vegetation experts.

(2) Regional efforts share a common set of methods (Walker, 1999), including using a single circumpolar image as a base map (Walker and others, 2000).

(3) Mapped polygons are defined by the dominant plant functional types (growth forms) and dominant plant communities, with community names linked to published plant association names or other plant community descriptions.

(4) The final map and GIS database will be useful for creating a common international framework for studying arctic vegetation, modeling vegetation change at the circumpolar scale, interpreting large scale patterns of wildlife distribution and migration, making regional or larger scale land management decisions, and educating people.

(5) The map will be constructed at the 1:4,000,000 scale and published at the 1:7,500,000 scale.

The mapping effort integrates information on soils, bedrock and surficial geology, hydrology, remotely sensed vegetation classifications, previous vegetation studies, and regional expertise to define polygons drawn using photointerpretation of a 1:4,000,000-scale composite AVHRR false color-infrared image (fig. 1). The AVHRR data were produced from 1993 and 1995 global AVHRR composite images produced by the U.S Geological Survey EROS Data Center in Sioux Falls, S.D., U.S.A. A minimum polygon size of 3.5 $\mathrm{mm}$ (14 $\mathrm{km}$ on the ground) was used for circular polygons and $2 \mathrm{~mm}(8 \mathrm{~km}$ on the ground) for linear polygons. Mapped areas were based on relatively homogeneous landscape units (either plains, hills, mountains, valleys, lakes, or glaciers) and substrate chemistry (nonacidic, acidic, or saline substrates), with boundaries visible on the AVHRR imagery.

Mapped polygons were linked to vegetation descriptions, associated biophysical properties, and descriptive literature through a series of lookup tables. The polygon maps and associated table information were entered into a GIS to produce maps of vegetation and associated ecosystem properties.

The region mapped for the Canadian Arctic component of the CAVM represents nearly 50 percent of the ice-free land area found north of the treeline. Vegetation patterns in the Canadian Arctic are primarily controlled by climate, substrate, and topography. Summer climate exerts the strongest control, affecting patterns of species richness, vegetation cover, biomass, and net primary productivity, along a $12^{\circ} \mathrm{C}$ mean July temperature gradient from treeline at the southern boundary of the map, to the low-lying Queen Elizabeth Islands in the north. Differences in substrate chemistry strongly affect species composition, and there are many species restricted to either acidic or nonacidic substrates. The contrast between vegetation in the acidic substrates of the Canadian Shield and in the nonacidic substrates of the Arctic Archipelago and the uplifted marine sediments is one of the dominant patterns of vegetation in the region. Within bioclimatic zones and substrate types, dominant topographic features and the resulting moisture regimes determine which plant communities are most abundant in a given landscape. Variation in dominant 
topography has been mapped as a series of landscape units characterized as lowland or upland plains, hills, mountains, and coastal areas. These landscape units, visible to a great extent in the AVHRR imagery, form the basis for the variation in vegetation and ecosystem properties mapped in the Canadian Arctic (fig. 1).

A number of ancillary datasets were useful in creating the Canada map. Bioclimatic zonation (fig. 2a; Yurtsev, 1994; Elvebakk and others, 1999; Gould and others, in review) is often based on vegetation patterns, which are strongly controlled by summer warmth (Young, 1971 and Rannie, 1986). Elevation patterns (fig. 2b) in the Canadian Arctic influence vegetation as summer warmth decreases with elevation. Additionally, lowlands are typically dominated by wet and mesic vegetation, uplands are typically dominated by mesic and dry vegetation, and mountains are typically dominated by dry vegetation. Patterns of parent-material chemistry indicate acidic (Canadian Shield granites and gneiss, acidic till) and nonacidic (sedimentary bedrock, uplifted marine sediments, loess dominated areas) substrates (fig. 2c), which affect plant species composition and vegetation patterns. Other layers include percentage of lake cover (fig. 2d), landscape units (fig. 2e), variation in maximum NDVI (fig. 2f), previous vegetation studies (fig. $2 \mathrm{~g}$ ), and the AVHRR base map (fig. 2h).

The mapped area includes 2.553 million square kilometers of land and freshwater lakes. It is about evenly split between low arctic (subzones 4 and 5), and high arctic (subzones 1-3) (Gould and others, in review). Nineteen landcover types include glaciers, fresh water, and 17 vegetation complexes characterized by the dominant dry, mesic, or wet plant communities characteristic of the dominant landscape features and climatic regime of each polygon (fig. 3). Plant functional types (fig. 4a) vary along climatic gradients (latitudinal and elevation) and range from low deciduous shrub in the southern Arctic (mean July temperatures 9-12 ${ }^{\circ} \mathrm{C}$ ), dwarf deciduous and evergreen shrubs (mean July temperatures 5-9 ${ }^{\circ} \mathrm{C}$ ), prostrate deciduous and evergreen shrubs (mean July temperatures $3-5^{\circ} \mathrm{C}$ ), and cushion forbs and bryophytes beyond the northern limit of woody plants (mean July temperatures $<3^{\circ} \mathrm{C}$ ). The canopy cover or horizontal vegetation structure (fig. 4b) decreases with latitude and elevation, and on extremely coarse, calcareous, or acidic substrates. Roughly one-third of the region is barren and semibarren, with less than 50-percent vegetation cover (polar desert and semidesert (sensu Bliss, 1997)), and two-thirds of the region is more completely covered with tundra vegetation. Biomass (fig. 4c) and annual net primary productivity (ANPP) (fig. 4d) are also strongly controlled by climate, substrate, and topography, with about 90 percent of the total biomass for the region concentrated in 30 percent of the land area in the more productive Low Arctic. 


\section{References}

Bliss, L.C., 1997, Arctic ecosystems of North America, in: Polar and Alpine Tundra. F.E. Wielgolaski, ed: Amsterdam, Elsevier, p. 551-684.

Dierssen, K., 1996, Vegetation Nordeuropas: Stuttgart, Ulmer.

Elvebakk, A., Relven, R., and Razzhivin, V., 1999, Delimitation, zonal and sectorial of the Arctic for the Panarctic Flora Project, in: The Species Concept in the High North - A Panarctic Flora Initiative, I. Nordal and V.Y. Razzhivin, eds.: Oslo, The Norwegian Academy of Science and Letters, p. 375-386.

Gould, W.A. and Walker, M.D., 1999, Plant communities and landscape diversity along a Canadian Arctic river: Journal of Vegetation Science, v. 10, p. 537-548.

Gould, W.A., Walker, D.A., Raynolds, M., Maier, H., Edlund, S., and Zoltai,S., in review, Canadian Arctic Vegetation Map: International Journal of Remote Sensing.

Lambert, J.D.H., 1968, The ecology and successional trends in the Low Arctic subalpine zone of the Richardson and British Mountains of the Canadian western arctic: Vancouver, University of British Columbia, v. 164.

Rannie, W.F., 1986, Summer air temperature and number of vascular species in arctic Canada: Arctic, v. 39, p. 133-137.

Walker, D.A., 1999, An integrated vegetation mapping approach for northern Alaska (1: $4 \mathrm{M}$ scale): International Journal of Remote Sensing, v. 20, p. 2895-2920.

Walker, D.A., 2000, Hierarchical subdivision of Arctic tundra based on vegetation response to climate, parent material, and topography: Global Change Biology, v. 6, p. 19-34.

Young, S. B., 1971, The vascular flora of St. Lawrence Island with special reference to floristic zonation in the arctic regions: Contributions from the Gray Herbarium, v. 201, p. 11-115.

Yurtsev, B.A., 1994, Floristic division of the Arctic: Journal of Vegetation Science, v. 5, p. 765-776. 


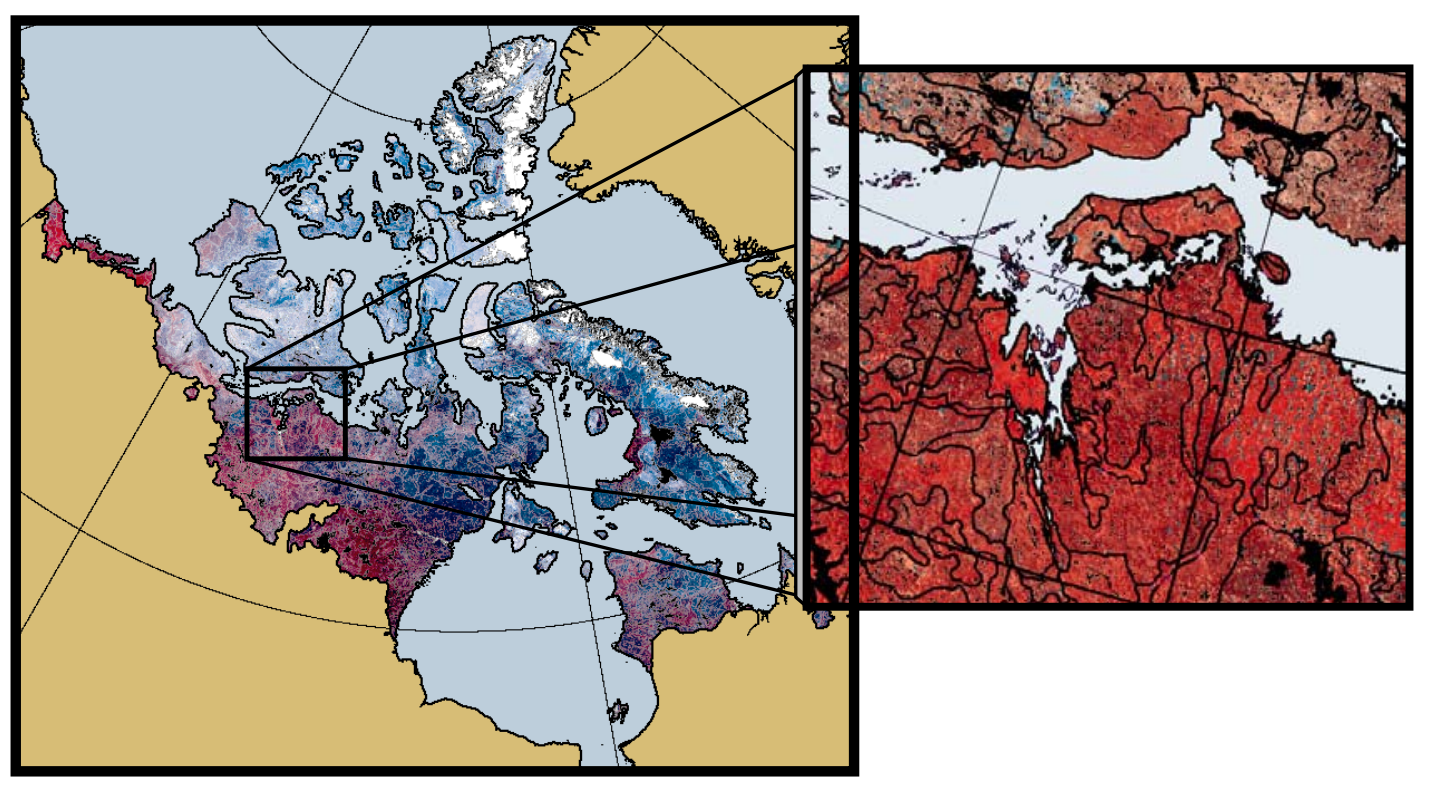

Figure 1. Polygons created by photointerpretation of AVHRR color-infrared satellite imagery with ancillary information on soils, topography, substrate chemistry, maximum NDVI signal, previous vegetation maps and studies, and expert knowledge. 

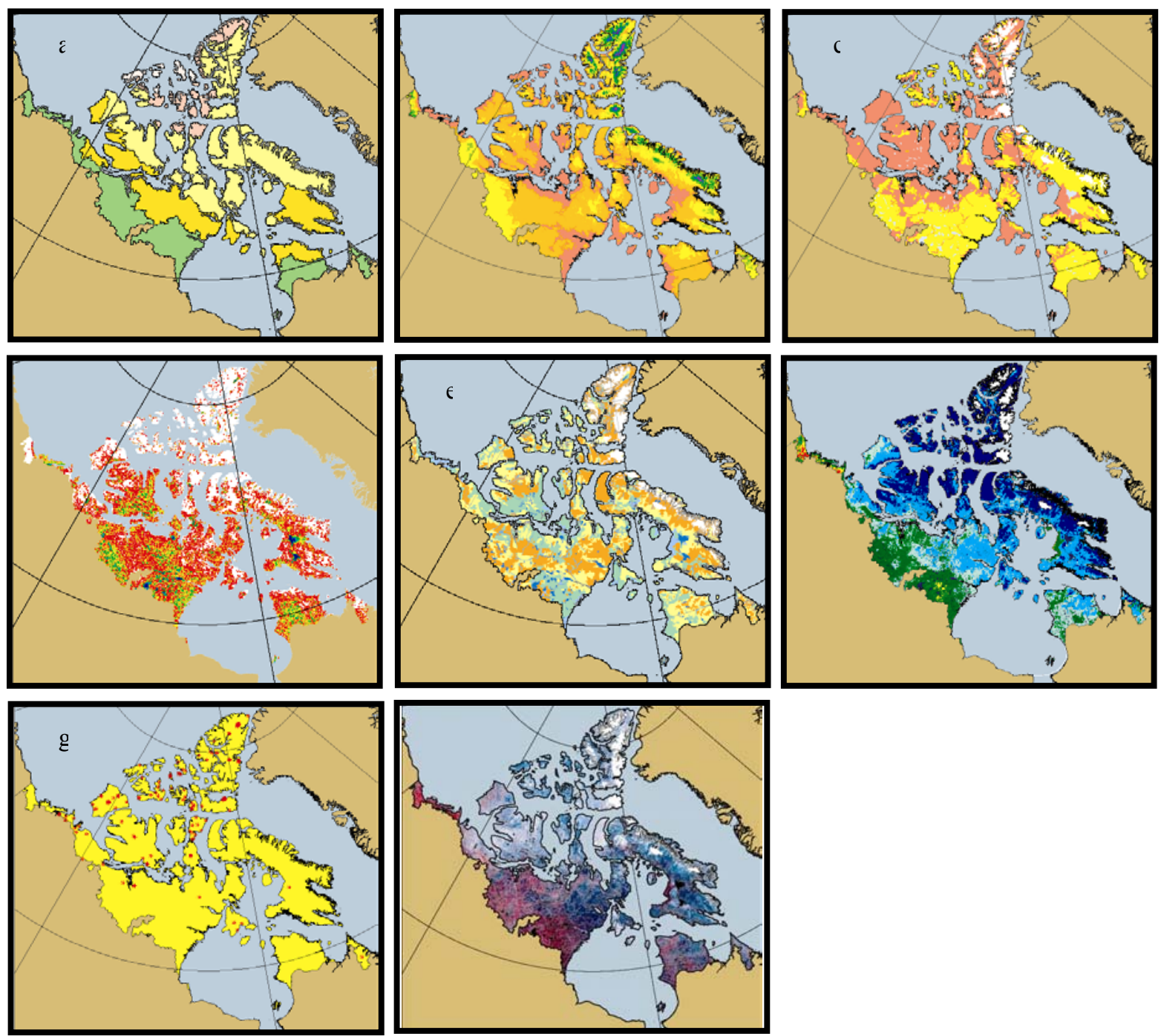

Figure 2. Some of the important ancillary data layers used in creating the Canada GIS database include (a) bioclimatic zonation patterns indicating five arctic subzones, (b) elevation patterns in the Canadian Arctic, (c) patterns of parent material chemistry indicating acidic and nonacidic, (d) percentage lake cover, (e) landscape units, (f) maximum NDVI for the Canadian Arctic, (g) locations of previous vegetation studies, and (h) AVHRR base map. 


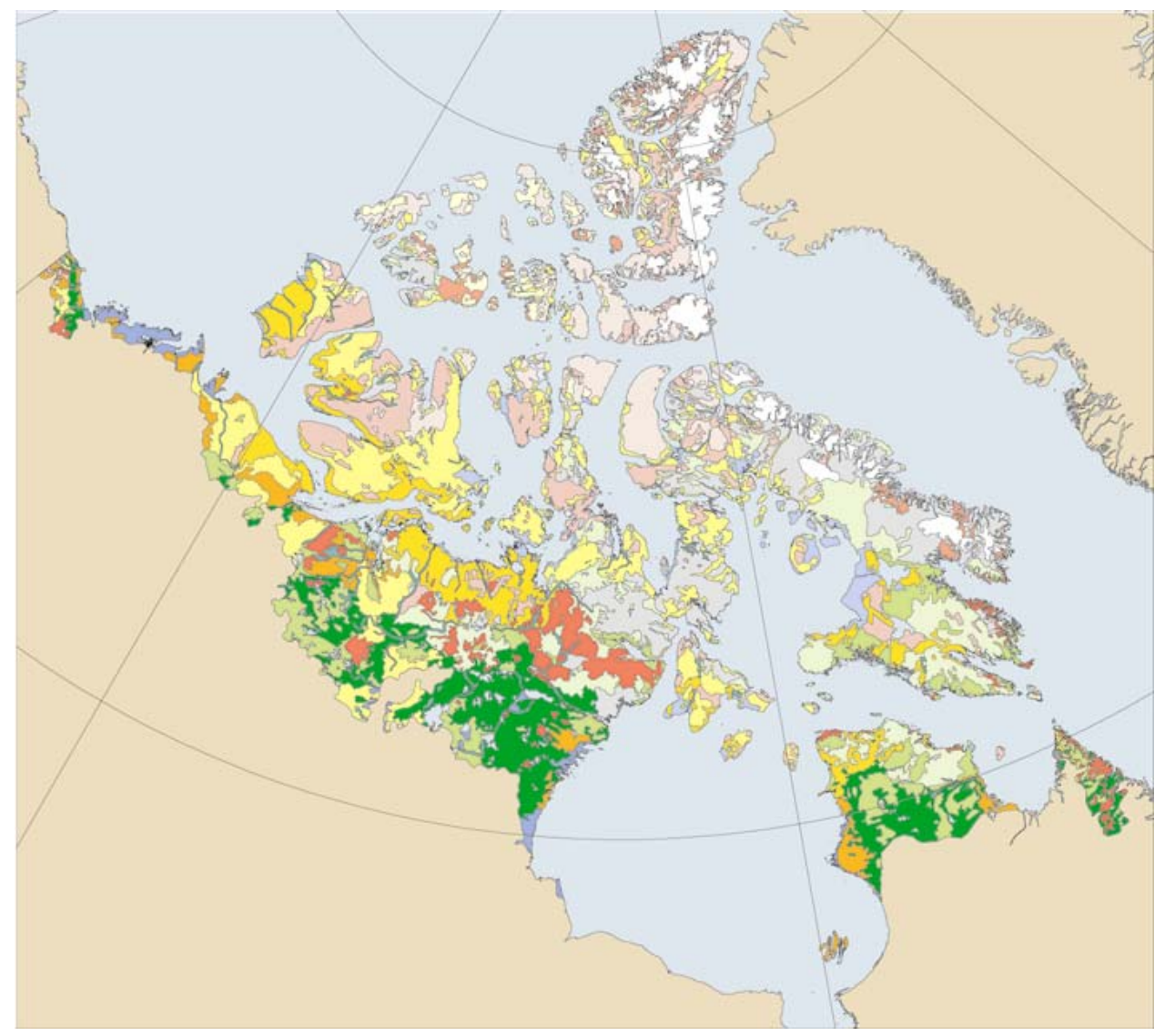

\section{Legend}

Dry

Cryptogam barrens. $<5 \%$ cover.

Cushionforbbarr ens Papaver etumdahlianae (Diessen 1996)with Papaver dahliana and Saxifraga oppositifolia. $<5 \%$ cover

Prostratedwarfshrubtumdra (nonacidic). Canici-Dnyadetumintegifoliae with Dryas integrifolia and Carex rupestris. $5-50 \%$ cover.

Prostratedwarfshrub-lichentundra (acidic). Salixar ctica -Dyyasintegifolia comm. 5-50\% cover.

(acidic). Salixar cica -Dryasintegifolia

Hemiprostrate dwarf shrub-lichen tundra (acidic). Vaccinium
Ledum decumbens comm. with Betula glandulosa. 5-50\% cover.

Mesic

Graminoid-forb tundra. Papaveretum dahlianae (Dierssen 1996) with

Papaver dahliana and Luzula confusa. 5-80\% cover.

Prostrate dwarf-shrub-graminoid tundra (nonacidic). Carici-Dryadetum integrifoliae, Caricetum misandrae. 5-80 \% cover.

Hemipr ostratedwarfshrubtundra (acidic). Vaccinumuliginosum-Cassiope

tetragona comm. with Salix arctica. $50-80 \%$ cover.

Erectdwarfshrub-graminoidtundra (nonacidic).Carexatrofisca-Salix

lanata with Oxytropis and Astragalus spp. 80-100\% cover.

Erect dwarf-shrub tundra (acidic). Betulo-ledetum decumbentis (Lambert 1968). $80-100 \%$ cover.

Low shrub-graminoid tundra. Dryado-integrifoliae-Carecetum bigelowii, Sphagno-Eriophor etumvaginati . Nonacidicandtussocktundra $10 \% \%$ cover

Low shrub tundra. Hierochloë alpina-Betula glandulosa comm. (Gould

and Walker 1999). $100 \%$ cover.

\section{Wet}

Grass-moss tundra. Alopecuris alpinus-Campylium arcticum comm. 5-50\% cover

Sedge-moss tundra. Carex aquatilis var. stans-

Drepanocladus revolutum. $80-100 \%$ cover.

$\square$ Low shrub-sedge-moss tundra. Carex aquatilis var. stansDrepanodadusr exolutum comm. With Salix spp. $100 \%$ cover

\section{Riparian}

Forb-graminoid barrens. Cerastium regelii-Papaver dahliana comm. with Alopecuris alpinus. $\quad<5 \%$ cover.

Lowshrub-graminoidforbcomplex. Epilobiumlatifolium-Salix

alaxensis and Salixpulchra-Car exaquatilis comms. 5-100\% \%over

\section{Water}

$>75 \%$ lake cover

\section{Glaciers}

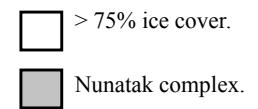

Nunatak complex.

Figure 3. Nineteen landcover types indicating dominate plant communities. 

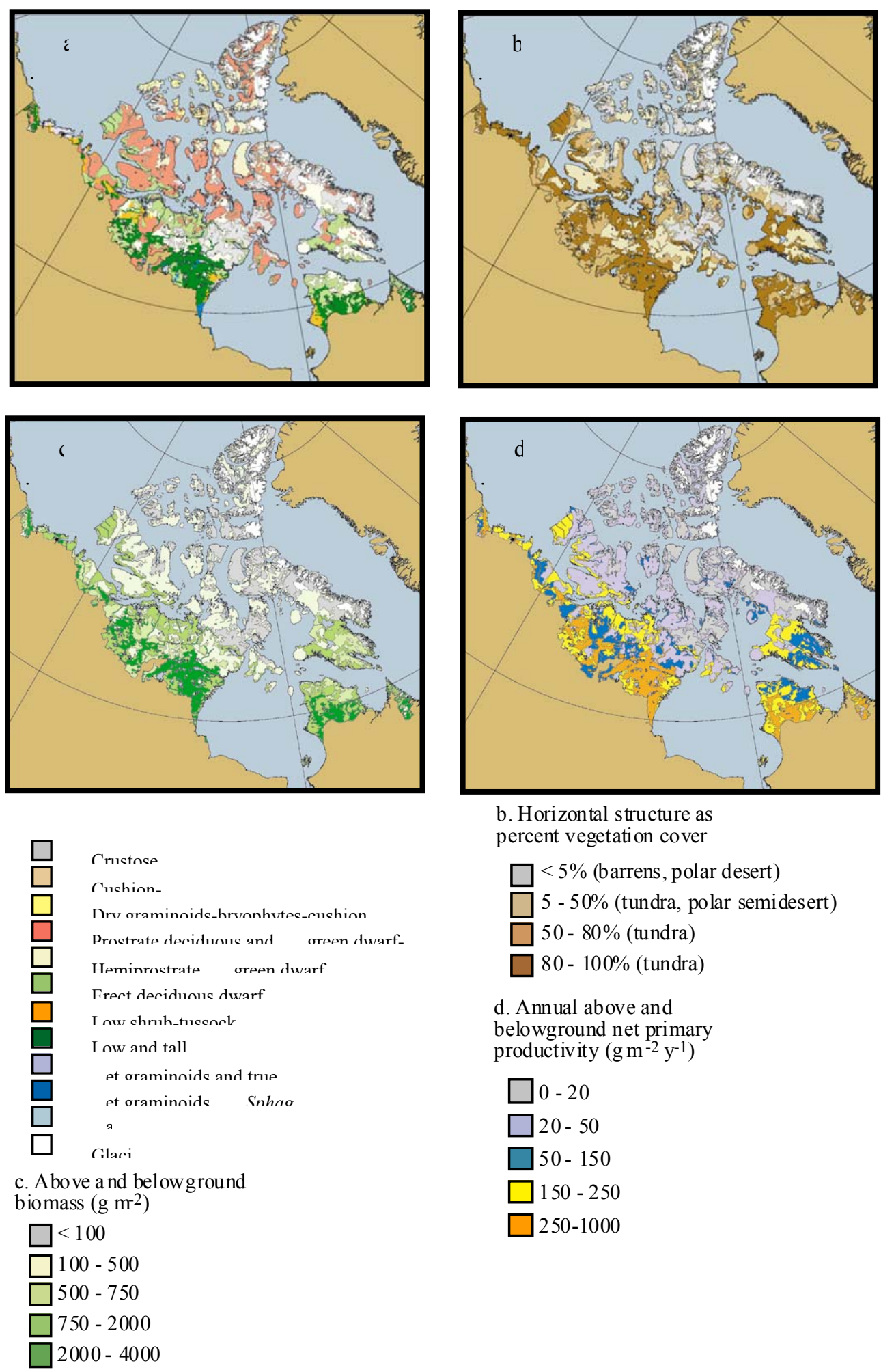

b. Horizontal structure as percent vegetation cover

$\square<5 \%$ (barrens, polar desert)
$\square 5-50 \%$ (tundra, polar semidesert)
$\square 50-80 \%$ (tundra)
$\square 80-100 \%$ (tundra)

d. Annual above and belowground net primary productivity $\left(\mathrm{g} \mathrm{m}^{-2} \mathrm{y}^{-1}\right)$

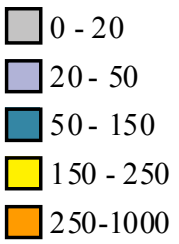

Figure 4. Derived maps indicating (a) dominant plant functional types, (b) percentage of vegetation cover, (c) aboveground and belowground biomass, and (d) annual net primary productivity. 


\title{
SYNTHESIS OF THE ALASKAN AND CANADIAN PORTIONS OF THE CAVM MAP
}

\author{
M.K. Raynolds and D.A. Walker \\ Institute of Arctic Biology, University of Alaska \\ Fairbanks, Alaska, USA 99775 \\ E-mail: fnmkr@uaf.edu,ffdaw@uaf.edu \\ W.A. Gould \\ International Institute of Tropical Forestry, \\ USDA Forest Service, Rio Piedras, PR 00928 \\ E-mail: IITF_COOP@upr.edu \\ C.J. Markon \\ Raytheon Corp. \\ USGS/EROS Alaska Field Office \\ 4230 University Dr. \\ Anchorage, Alaska., USA 99508-4664 \\ E-mail: markon@usgs.gov
}

One of the goals of the CAVM project was to be able to take advantage of local expertise and resources, while still ending up with a unified map. To meet this goal, the same base map was used by all mappers (1:4,000,000-scale AVHRR CIR imagery), and everyone followed the same mapping methods (Walker, 1999). Canada and three areas of Alaska were mapped separately and subsequently combined. Matching the polygons was straightforward, but matching interpretations proved to be more complicated. Source differences included dissimilarity in the landscapes being mapped, differences in the scale and reliability of background information, and personal ground experience. Each mapper had to decide which data were the most reliable to determine where to draw polygon boundaries. There were also some differences in the way the method was applied. After these differences were resolved, the polygons were combined, and maps produced for the whole area.

The combined map was made using ARC/INFO 8.0.2 on a Sun workstation. Each area of Alaska was treated as a separate polygon coverage (North Slope, Seward Peninsula, and Southwest Alaska); the Canadian arctic was mapped as seven different coverages. Each coverage contained a polygon attribute table with attributes describing the background data for the polygons such as subzone and geology. There were some differences in the way bioclimatic subzones and floristic provinces were treated by the different mappers. Some integrated the boundaries during the mapping process, in other cases, the boundaries were kept separate, being overlaid on the base map and combined later. The reasons for leaving them separate were that these boundaries are not directly related to physiographic features, and are not well defined in many areas; however, there were advantages to integrating these boundaries into the mapping process. The subzones, being course features, can usually fit along existing polygon boundaries. Once the subzones and provinces are incorporated, they can be easily mapped and updated within Arc/Info. They are also necessary for producing the final derived maps, since data in the lookup tables, such as biomass, depend on the subzone.

Mapping bioclimatic subzones also brought up the question of how to account for elevation. Since the subzones are partly defined on the basis of mean July temperature, changes in elevation can be equated with changes in zone, using the adiabatic cooling rate. A 500-m increase in elevation results in an approximately $3^{\circ} \mathrm{C}$ decrease in temperature, which is equivalent to one subzone. This issue was considered in the Brooks Range of Alaska by Cantlon (1961), who concluded that alpine communities are not equivalent to arctic communities. Also, the most obvious changes in vegetation occur in areas with steep mountains, where the topography is too complicated to map elevation bands (at our 1:4,000,000scale). In areas where elevation changes are more gradual, such as the Canadian Shield, the differences in 
vegetation are not as distinct. So, while there may be advantages in considering zonal changes with elevation at some scales, it was not a useful technique for this project.

The soils information provides an example of background data that came from a number of different base maps, with different legends and scales. It is possible to create a soils map for the entire area, because the soils data are part of the attribute file associated with each polygon. However, the map would have no unified legend: similar soils may have different names, coming from different soil-mapping traditions. Even though it may not be useful to produce a circumpolar soils map from these data, they are still useful in describing individual polygons. This type of variation in the different data layers is thus accommodated within the method without adversely affecting the final product.

All the geologic and terrain information was used in determining where to draw the polygon boundaries for the Integrated Land Unit Map (ILUM) (fig.1). The individual Alaskan and Canadian ILUM maps combined well, because they were mapped using a similar legend (Walker, 1999). Using the same AVHRR base map and minimum mapping requirements resulted in overall similarity in polygon size and complexity, despite some difference due to terrain types.

After the ILUM layer was created, any additional information relating to vegetation was added to the map. Phytogeographic subzone and floristic province boundaries were added, and in some cases this required dividing polygons. Anything visible on the imagery that was not accounted for by physiography, such as shrubiness, was added at this stage. Any other aspects of vegetation not visible on the imagery, but known through local knowledge to be important to vegetation distribution, were added to the map at this point.

The result was the final polygon coverage, which was used to produce a vegetation map showing dominant physiognomic types. This version of the vegetation map (fig. 2) uses the legend developed by Bill Gould for Canada (Gould and others, 2000). The detailed legend is based on the physiognomy of the vegetation and includes a description of the dominant vegetation community and horizontal cover (fig. 3).

The final step for combining the project areas was to assemble the lookup tables relating ecological characteristics to the mapped polygons. The first part consisted of a summary table of plant communities found in each area. Table 1 is an example of this type of table for dry communities of the North Slope of Alaska. The communities are listed by subzone and substrate (acidic/nonacidic) and according to their location along a topographic sequence - either dry, moist, wet, snowbed, or riparian. The communities are referenced and numbered, so that they can be referred to in the second table.

The second table linked the communities listed in the first table with the mapped polygons, listing primary, secondary, and tertiary communities forming the vegetation complex within that polygon. The table also characterized the dominant vegetation physiognomy and the productivity values of that polygon. Table 2 is an example of this table for subzone 4 of the North Slope of Alaska. In cases where subzones, shrubiness, or other characteristics were used to divide ILUM polygons, these variables must be part of the polygon identification column in the table. This table can be used to create a variety of derived maps, such as biomass (fig. 4). 


\section{References}

Cantlon, J.E. 1961, Plant cover in relation to macro-, meso- and micro-relief: Office of Naval Research. Final Report, Grant \#ONR-208 and 216, $128 \mathrm{p}$.

Gould, W.A., Raynolds, M.K., Walker, D.A., Maier, H.A., Edlund, S., and Zoltai, S., 2000, Canadian Arctic Vegetation - an integrated vegetation complex map for the Circumpolar Arctic Vegetation Mapping project: Poster presented at the 6th Annual Circumpolar Remote Sensing Conference, Yellowknife NT, Canada, June 12-14, 2000.

Walker, D.A., 1999, An integrated vegetation mapping approach for northern Alaska (1:4M scale): International Journal of Remote Sensing, v. 20, p. 2895-2920. 


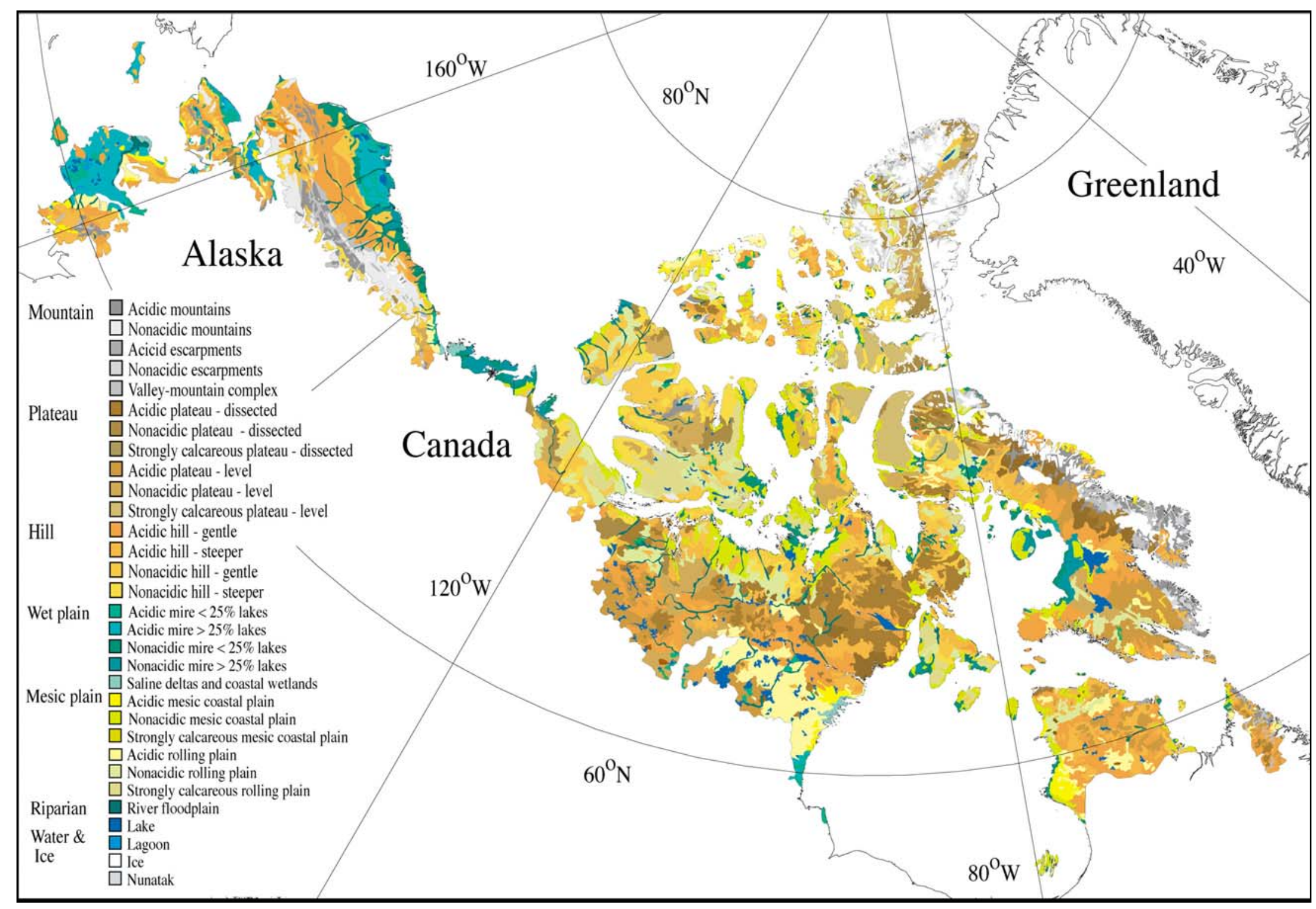

Figure 1. Preliminary integrated terrain unit map for Canada and Alaska. 


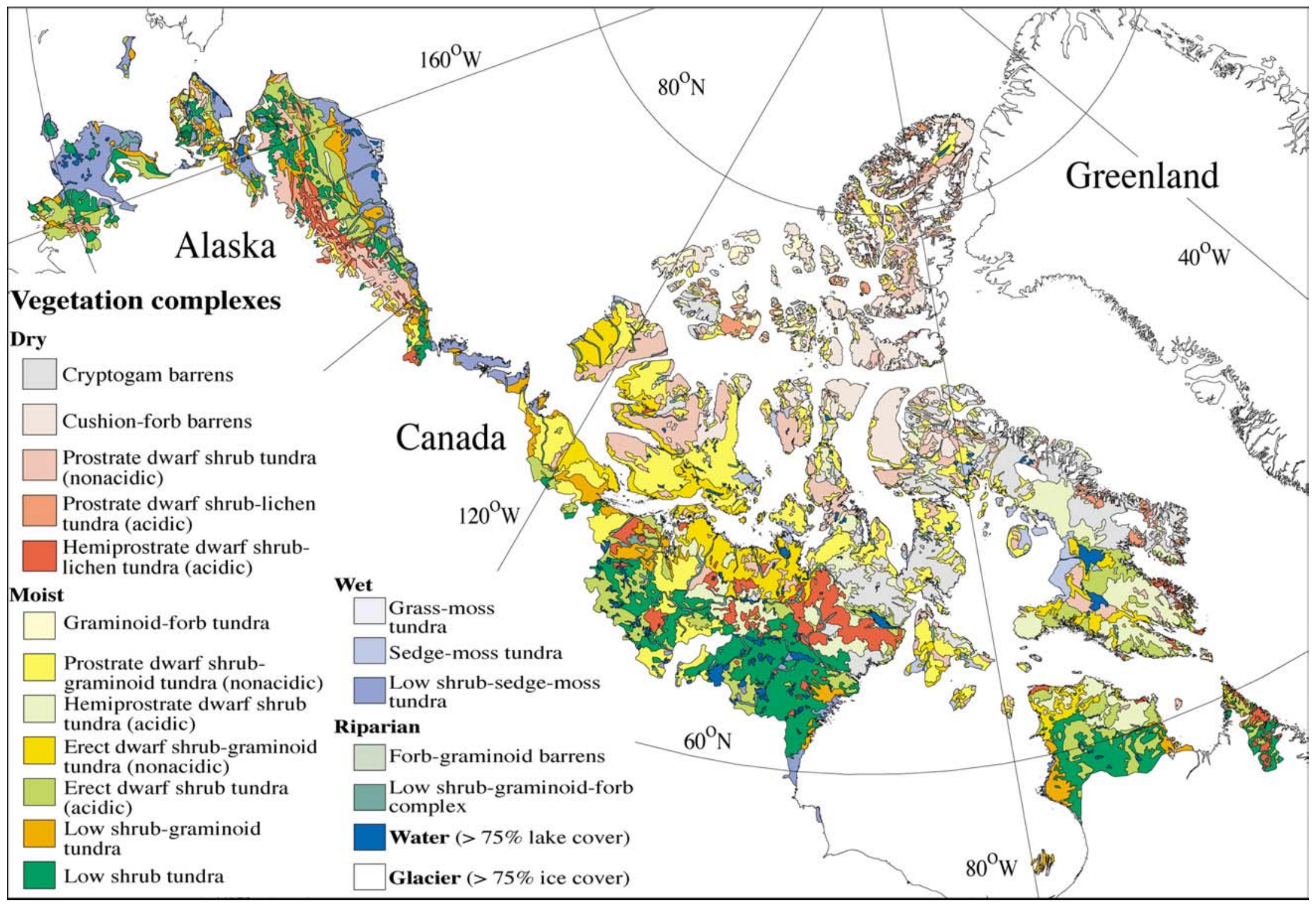

Figure 2. Preliminary map of dominant physiognomy for Canada and Alaska. 


\section{Dry}

Cryptogam barrens. Hierochloë alpina-Rhizocarpon geographicum comm. (Gould and Walker 1999), Cetraria nigricans- Rhizocarpon geographicum comm. (Walker et al. 1994). < 5\% cover.

Cushion-forb barrens. Papaveretum dahlianae (Dierssen 1996) with Papaver dahliana and Saxifraga oppositifolia. $<5 \%$ cover.

Prostrate dwarf-shrub tundra (nonacidic). Carici-Dryadetum integrifoliae (Daniëls 1982) with Dryas integrifolia and Carex rupestris. 5-50\% cover.

Prostrate dwarf-shrub-lichen tundra (acidic). Salix arctica-Dryas integrifolia comm. 5-50\% cover.

Hemiprostrate dwarf shrub-lichen tundra (acidic). Vaccinium vitis-idaeaLedum decumbens comm. with Betula glandulosa. 5-50\% cover.

\section{Mesic}

Graminoid-forb tundra. Papaveretum dahlianae (Dierssen 1996) with Papaver dahliana and Luzula confusa. 5-80\% cover.

Prostrate dwarf-shrub-graminoid tundra (nonacidic). Carici-Dryadetum integrifoliae (Daniëls 1982) with Carex misandra. 5-80\% cover.

Hemiprostrate dwarf-shrub tundra (acidic). Vaccinium uliginosum-Cassiope tetragona comm. with Salix arctica. $50-80 \%$ cover.

Erect dwarf-shrub-graminoid tundra (nonacidic). Carex atrofusca-Salix lanata ssp. richardsonii, Equisetum arvense-Salix lanata ssp. richardsonii comms. (Gould and Walker 1999) with Oxytropis spp. 80-100\% cover.

Erect dwarf-shrub tundra (acidic). Betulo-ledetum decumbentis (Lambert 1968). $80-100 \%$ cover.

Low shrub-graminoid tundra. Dryado integrifoliae-Caricetum bigelowii, Sphagno-Eriophoretum vaginati (Walker et al. 1994), Saussuria angustifoliaDryas integrifolia comm. (Gould and Walker 1999). Nonacidic and tussock tundra. $100 \%$ cover.

Low shrub tundra. Hierochloë alpina-Betula glandulosa comm. (Gould and Walker 1998). 100\% cover.

Figure 3. Dominant plant physiognomy for Canada (Gould and others, 2000).

\section{Wet}

Grass-moss tundra. Alopecuris alpinus-Campylium arcticum comm. $5-50 \%$ cover.

Sedge-moss tundra. Carex aquatilis var. stansDrepanocladus revolutum comm. 80-100\% cover.

Low shrub-sedge-moss tundra. Carex aquatilis var. stansDrepanocladus revolutum comm. with Salix spp., Carex aquatilis-C. chordorrhiza comm. (Gould and Walker 1999). $100 \%$ cover.

\section{Riparian}

Forb-graminoid barrens. Cerastium regelii-Papaver dahliana comm. with Alopecuris alpinus. $<5 \%$ cover.

Low shrub-graminoid-forb complex. Epilobium latifolium-Salix alaxensis and Salix pulchra-Carex aquatilis comms. (Gould and Walker 1999) $5-100 \%$ cover.

\section{Water}

\section{$\square>75 \%$ lake cover.}

\section{Glaciers}

\section{$>75 \%$ ice cover. \\ Nunatak complex.}




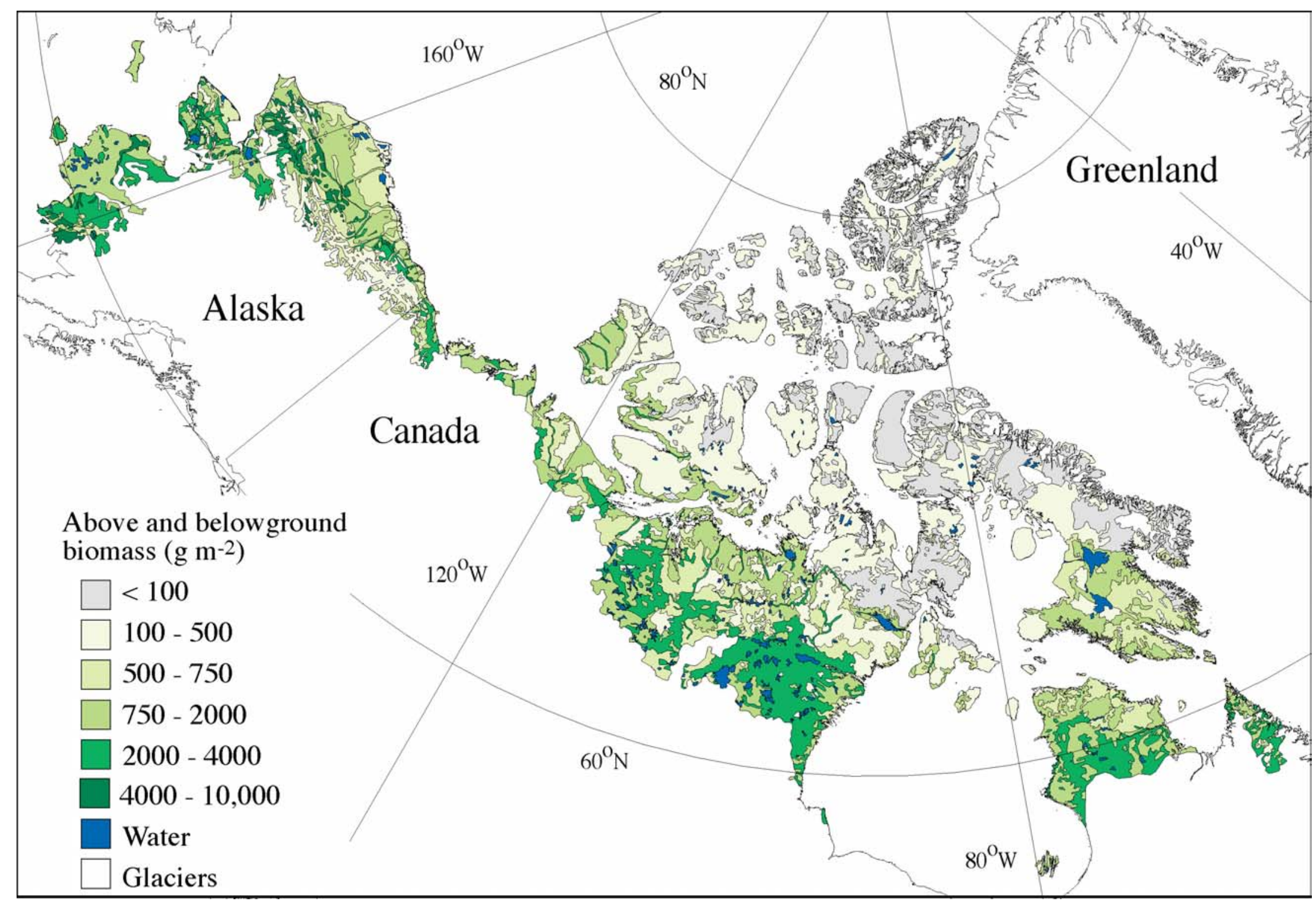

Figure 4. Preliminary map of biomass values for the Canadian and Alaskan arctic in $\mathrm{g}^{\cdot} \mathrm{m}^{-2}$. 
Table 1. A portion of the summary table for plant communities of the Seward Peninsula, Alaska

\begin{tabular}{|l||l|l||}
\hline \multirow{2}{*}{$\begin{array}{l}\text { Habitat along } \\
\text { mesotopographic } \\
\text { gradient }\end{array}$} & Subzone 4 & Nonacidic substrates \\
\cline { 2 - 3 } & Acidic substrates & $\begin{array}{l}\text { 5. Prostrate dwarf shrub (Dryas integrifolia), } \\
\text { lichen Jorgenson, 2000 - Devil's Upland }\end{array}$ \\
\hline Dry & None described & N/A \\
\hline Snowbed & $\begin{array}{l}\text { 2. Sedge (Carex aquatilis), shrub } \\
\text { Ledum decumbens), moss (Sphagnum } \\
\text { spp.), Lichen (Cladina spp., Cladonia } \\
\text { spp.) Racine and Anderson, 1979 - } \\
\text { water sedge wet meadow; Swanson } \\
\text { and others, 1985, 55- cottongrass- } \\
\text { water sedge, low-centered polygons. }\end{array}$ & \\
\hline N/A & N/A \\
\hline
\end{tabular}


Table 2. Lookup table showing plant communities in each type of mapped polygon, and their physical characteristics, Seward Peninsula, Alaska

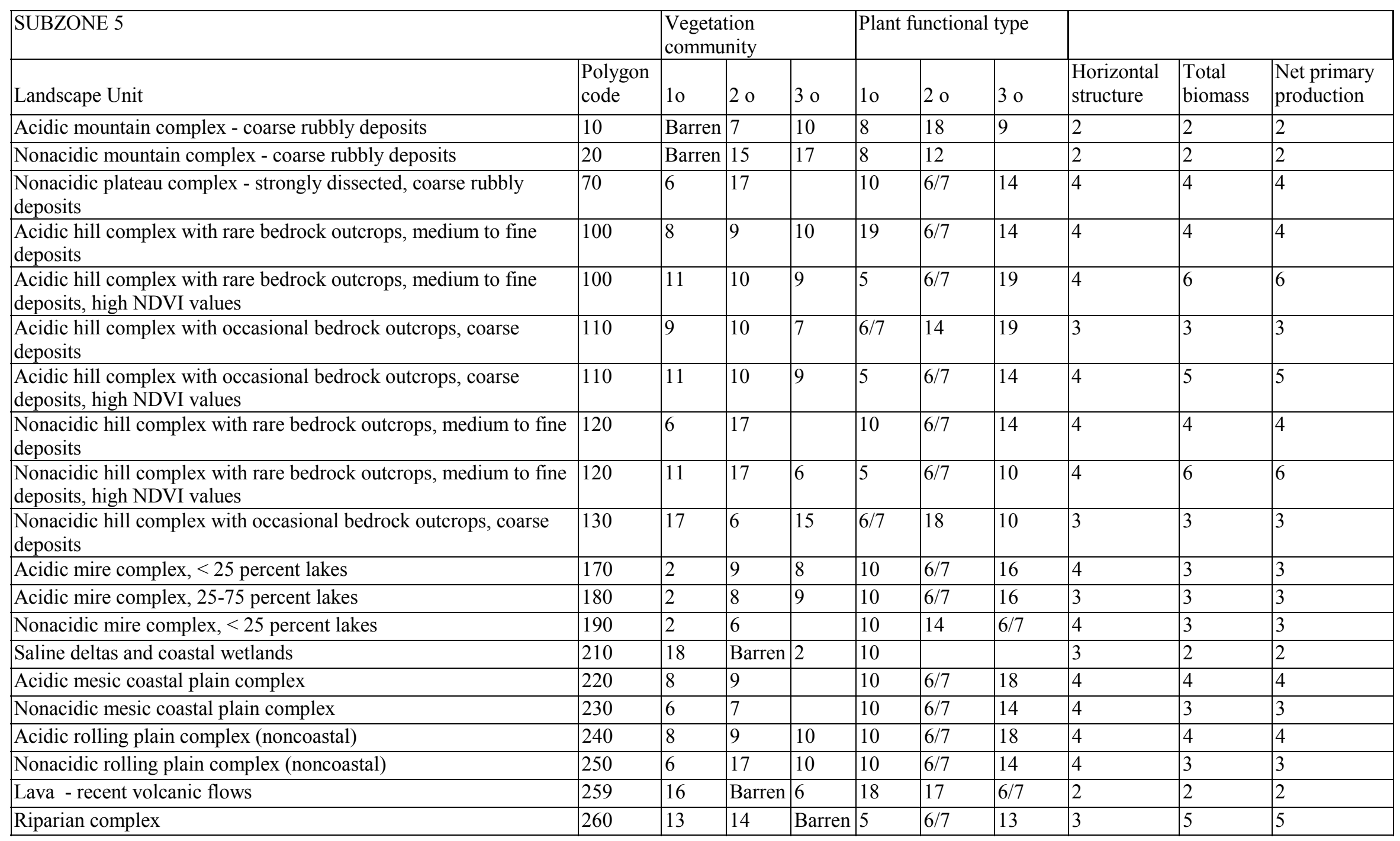




\title{
ON THE WAY TO AN INTEGRATED VEGETATION MAP OF GREENLAND
}

\author{
Fred J.A. Daniels and Maike Wilhelm \\ Institute of Plant Ecology, \\ Westphalian Wilhelms University, \\ Hindenburgplatz 55, 48143 Münster, Germany \\ E-mail: daniels@uni-muenster.de, \\ wilhema@uni-muenster.de
}

\section{Introduction}

There is an urgent need for a fundamental assessment and mapping of biodiversity in terms of vegetation and plant communities for the entire circumpolar Arctic according to uniform methods and language. Our vegetation research in Greenland intends to contribute to this task by developing (1) a vegetation classification system for all of Greenland according to the Braun-Blanquet concept and (2) vegetation maps in the framework of the international CAVM-Project (Walker, 1999).

In this contribution we present some preliminary results of our efforts. Regarding the mapping procedures, we principally followed the integrated vegetation mapping approach as described by Walker (1999).

\section{Integrated Landscape Unit Map (ILUM)}

The Integrated Landscape Unit Map (ILUM) includes bedrock and other terrain information relevant to the vegetation. Owing to the minimum polygon size of $3.5 \mathrm{~mm}$ working on a 4,000,000 scale, we simplified the coastline and inland ice margin as a first step. The landscape units were then delineated by integrating different landscape features: elevation (Digital Chart of the World), bedrock (Esher and Pulvertaft, 1995), soil (unpublished soil map provided by Dr. C. Bay, Copenhagen) and percentage cover of lakes (Walker, 2000). Figure 1 shows the ILUM of Greenland and the legend.

\section{Bioclimatic and vegetation subdivision}

We principally follow Elvebakk's and other's (1999) subdivision of the Arctic into five bioclimatic (sub) zones that are essentially characterized by temperature regimes (mean July temperatures) and vegetation features; however, we slightly modified the zonation scheme for Greenland and the nomenclature of the vegetation (sub) zones as follows: (1) Arctic Herb Zone, (2) Northern Arctic Dwarf Shrub Zone, (3) Middle Arctic Dwarf Shrub Zone, (4) Southern Arctic Dwarf Shrub Zone, (5) Arctic Shrub Zone, and (6) Boreal enclave in the inland in the South (cf. Daniels and others, 2000).

Figure 2 shows the vegetation (sub) zones of Greenland. The delineation of the (sub) zones should be taken as an approximation only and should be tested for those parts of Greenland where no or little information is available (cf. Daniels and others, 2000).

\section{Floristic subdivision}

The most recent floristic subdivision of Greenland is shown in figure 3. It was compiled from the results of the floristic studies by Bay (1992), Feilberg (1984), and Fredskild (1996), who revised the delineation of Böcher's and other's (1966) flora provinces for, respectively, North, South, and West Greenland. The floristic provinces in East Greenland are still taken from Böcher and others (1966).

\section{Prodrome of syntaxa/plant communities}

A look-up table (table 1) contains names of plant communities (according to the Braun-Blanquet approach), vegetation code, habitat information, and literature sources.

This preliminary and incomplete table is derived from major phytosociological and floristic studies in Greenland published in scientific books and journals (see attached Additional References). 


\section{Additional remarks}

In another look-up table we will list for each polygon (ilum), vegetation zone and floristic province vegetation information for the following habitats: dry open ridge, zonal (mesic) sites, early and late snowbed, mire/bog, water, riparian habitats, steppe sites, and dry and wet coastal habitats. Moreover, for mountain complexes with vertical vegetation zonation, vegetation information of these habitats, if present, will be provided for the following altitudinal belts: $0 \mathrm{~m}-350 \mathrm{~m}, 350 \mathrm{~m}-700 \mathrm{~m}, 700 \mathrm{~m}-1,000 \mathrm{~m}$, and >1,500 $\mathrm{m}$. Additional maps will contain out-of-scale information of special interest such as bird cliffs, oases, hot springs, and occurrence of rare species; additional tables will show areas of intensive vegetation studies. 


\section{References}

Bay, C., 1992, A phytogeographical study of the vascular plants of northern Greenlandnorth of $74^{\circ}$ northern latitude: Meddr. Gronl. Biosci., 36.

Böcher, T.W., Holmen, K., and Jakobsen, K., 1966, Gronlands Flora: Copenhagen, Haase and Sons.

Daniels, F.J.A., Bültmann, H., Lünterbusch, C., and Wilhelm, M., 2000, Vegetation zones and biodiversity of the NorthAmerican Arctic: Ber. d Reinh-Tüxen-Ges., v. 12, p. 131-151.

Elvebakk, A., Elven, R., and Razzhivin, V.Yu, 1999, Delimitation, zonal and sectorial subdivision of the arctic for the panarctic flora project: I. Mat.-Naturv. Klasse Skr. Ny Serie, Det Norske Videnskaps-Akademi, v. 38, p. 375-386.

Esher, J.C., and Pulvertaft, T.C.R.,1995, Geological Map of Greenland, 1:2.500.000: Copenhagen, GEUS.

Feilberg, J., 1984, A phytogeographical study of South Greenland. Vascular Plants: Meddr. Gronl. Biosci., 15.

Fredskild, B., 1996, A phytogeographical study of the vascular plants of West Greenland $\left(62^{\circ} 20^{\prime}-74^{\circ} 00^{\prime} \mathrm{N}\right)$ : Meddr. Gronl. Biosci. 45.

Walker, D.A., 1999, An integrated vegetation mapping approach for northern Alaska (1:4,000,000- scale): International Journal of Remote Sensing 20, v. 15 and 16, p. 2895-2920.

Walker, D.A., 2000, Draft map. False color-infrared image of Greenland, scale 1:4.000000: Fairbanks, University of Alaska, unpublished map.

\section{Additional References}

Bay, C., 1997, Floristical and ecological characterization of the polar desert zone of Greenland: Journal of Vegetation Science, v. 8, p. 685-696.

Böcher, T.W., 1933, Studies on the vegetation of the East Coast of Greenland. Meddr. Gronl., v. 104, no. 4.

Böcher, T.W., 1954, Oceanic and continental vegetational complexes in Southwest Greenland: Meddr. Gronl., v. 148 , no. 1.

Böcher, T.W., 1959, Floristic and ecological studies in middle West Greenland: Meddr. Gronl., v. 156, no. 5.

Böcher, T.W., 1963, Phytogeography of middle West Greenland: Meddr. Gronl., v. 148, no. 3.

Daniels, F.J.A., 1975, Vegetation of the Angmagssalik District Southeast Greenland. III. Epilithic macrolichen communities: Meddr. Gronl., v. 198, no. 3.

Daniels, F.J.A., 1982, Vegetation of the Angmagssalik District, Southeast Greenland, IV. Shrub, dwarf shrub and terricolous lichens: Meddr. Gronl. Biosci. 10.

Daniels, F.J.A., 1985, Floristic relationship between plant communities of corresponding habitats in Southeast Greenland and alpine Scandinavia. Vegetatio, v. 59, p. 145-150.

Daniels, F.J.A., 1994, Vegetation classification in Greenland: Journal of Vegetation Science, v. 5, p. 781-790.

Daniels, F.J.A., and De Molenaar, J.G., 1993, Dry coastal ecosystems of Greenland, in: Van der Maarel (ed.) Ecosystems of the World 2A, 39-50: Amsterdam, Elsevier.

Daniels, F.J.A., and Alstrup, V., 1996, On the vegetation of eastern North Greenland: Acta. Bot. Neerl., v. 45, p. 583.

De Molenaar, J.G., 1974, Vegetation of the Angmagssalik District, Southeast Greenland I. Littoral vegetation: Meddr. Gronl., v. 198, no. 1.

De Molenaar, J.G., 1976, Vegetation of the Angmagssalik District Southeast Greenland II. Herb and snow-bed vegetation: Meddr. Gronl., v. 198, no. 2.

De Molenaar, J.G.,1987, An ecohydrological approach to floral and vegetational pattern in Arctic landscape ecology: Arctic and Alpine Research, v. 19, p. 414-424.

Dierßen, K., 1992, Zur Synsystematik nordeuropäischer Vegetationstypen. 1. Alpine Vegetation und floristisch verwandte Vegetationseinheiten tieferer Lagen sowie der Arktis: Ber. d Reinh.-Tüxen-Ges., v. 4, p. 191-226.

Dierßen, K., 1996, Vegetation Nordeuropas: Stuttgart, Ulmer.

Elvebakk, A., 1999, Bioclimatic delimitation and subdivision of the Arctic. I. Mat.-Naturv. Klasse Skr. Ny Serie: Det Norske Videnskaps-Akademi., v. 38, p. 81-112.

Fredskild, B.,1961, Floristic and ecological studies near Jakobshavn, West Greenland: Meddr. Gronl., v. 163, no. 4. 
Fredskild, B., 1992, The Greenland limnophytes-their present distribution and Holocene history: Acta Botanica Fennica, v. 144, p. 93-113.

Fredskild, B., 1998, The vegetation types of Northeast Greenland: Meddr. Gronl. Biosci. 49.

Gelting, P.,1955, A West Greenland Dryas integrifolia community rich in lichens: Svensk. Bot. Tidskr., v. 49, p. 295-313.

Halliday, G., Klim-Nielsen, L., and Smart, I.H.M., 1974, Studies on the flora of the North Blosseville Kyst and the hot springs of Greenland: Meddr. Gronl., v. 199, no. 2.

Holmen, K., 1957, The vascular plants of Peary Land, North Greenland: A list of species found between Victoria Fjord and Danmark Fjord: Meddr. Gronl., v. 124, no. 9.

Knapp, R., 1964, Über Eigenschaften arktischer und subarktischer Vegetation am Beispiel der Pflanzenwelt in einigen Gebieten des südlichen Grönland: Ber. Oberhess. Ges. Nat. Heilk., v. 33, p. 91-129.

Lünterbusch, C., Bültmann, H., and Daniels, F.J.A., 1997, Eine pflanzensoziologische Übersicht der Oxyria digyna und Chamaenerion latifolium-Vegetation im küstennahen Bereich Südost-Grönlands: Polarforschung, v. 65, no. 2, p. 7182.

Raup, H.M., 1971, Miscellaneous contributions of the vegetation of the Mesters Vig District, Northeast Greenland: Meddr. Gronl. v., 194, no. 2.

Schwarzenbach, F.H., 2000, Altitude distribution of vascular plants in mountains of East and Northeast Greenland, Meddr. Grönl. Biosci., v. 50.

Seidenfaden, G., and Sörensen, T., 1937, The vascular plants of Northeast Greenland from $74^{\circ} 30^{\circ}$ to $79^{\circ} 00^{\circ}$ N. lat: A summary of all species found in East Greenland: Meddr. Gronl., v. 101.

Stumböck, M., 1993, Vegetation und Ökologie von Narsarsuaq, Südwestgrönland. Diss. Bot., v. 203.

Vestergaard, P., 1978, Studies in vegetation and soil of coastal salt marshes in the Disko Area, West Greenland, Meddr. Gronl., v. 204, no. 2. 


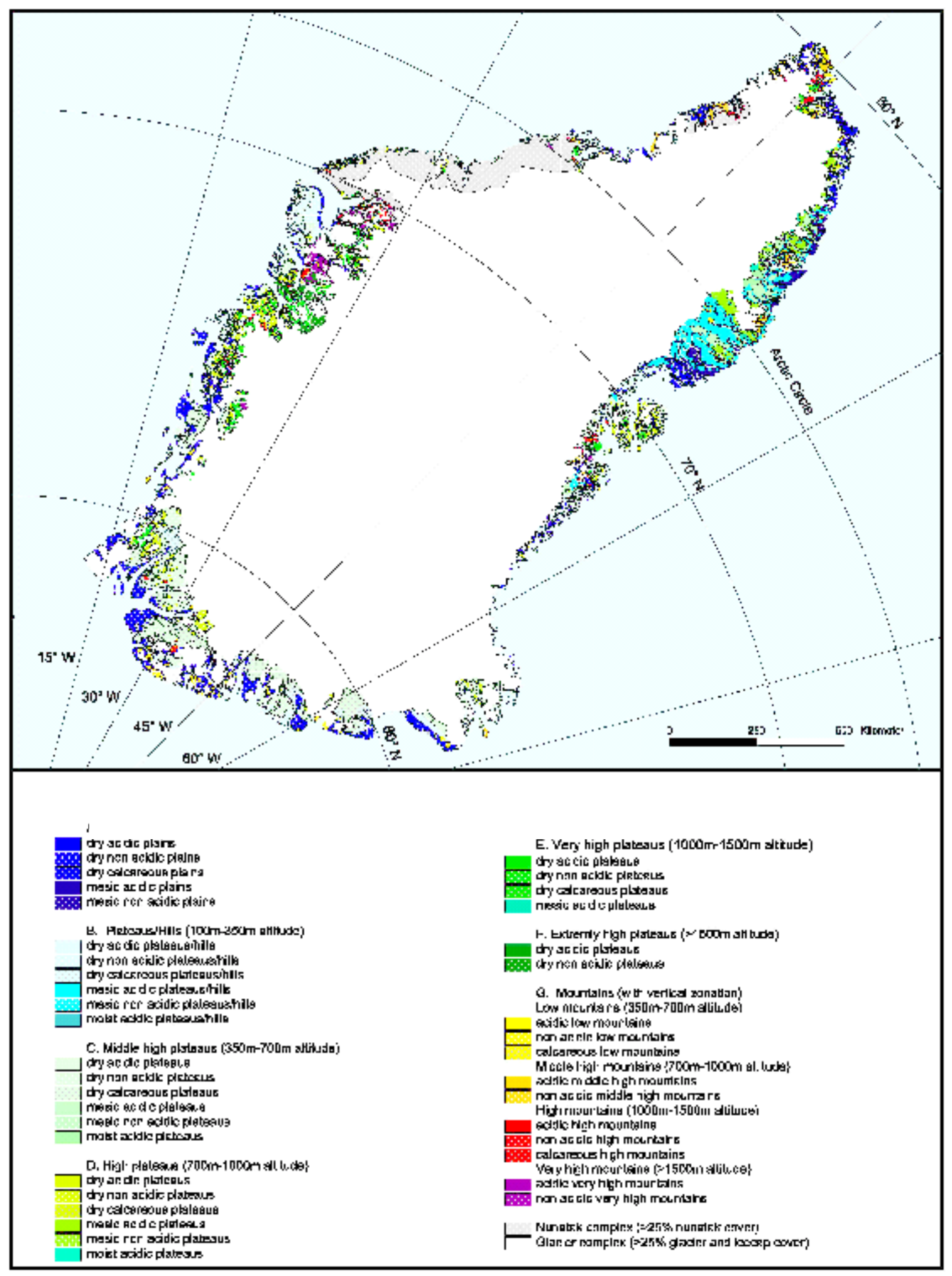

Figure 1. Integrated Landscape Unit Map (ILUM) for Greenland. 


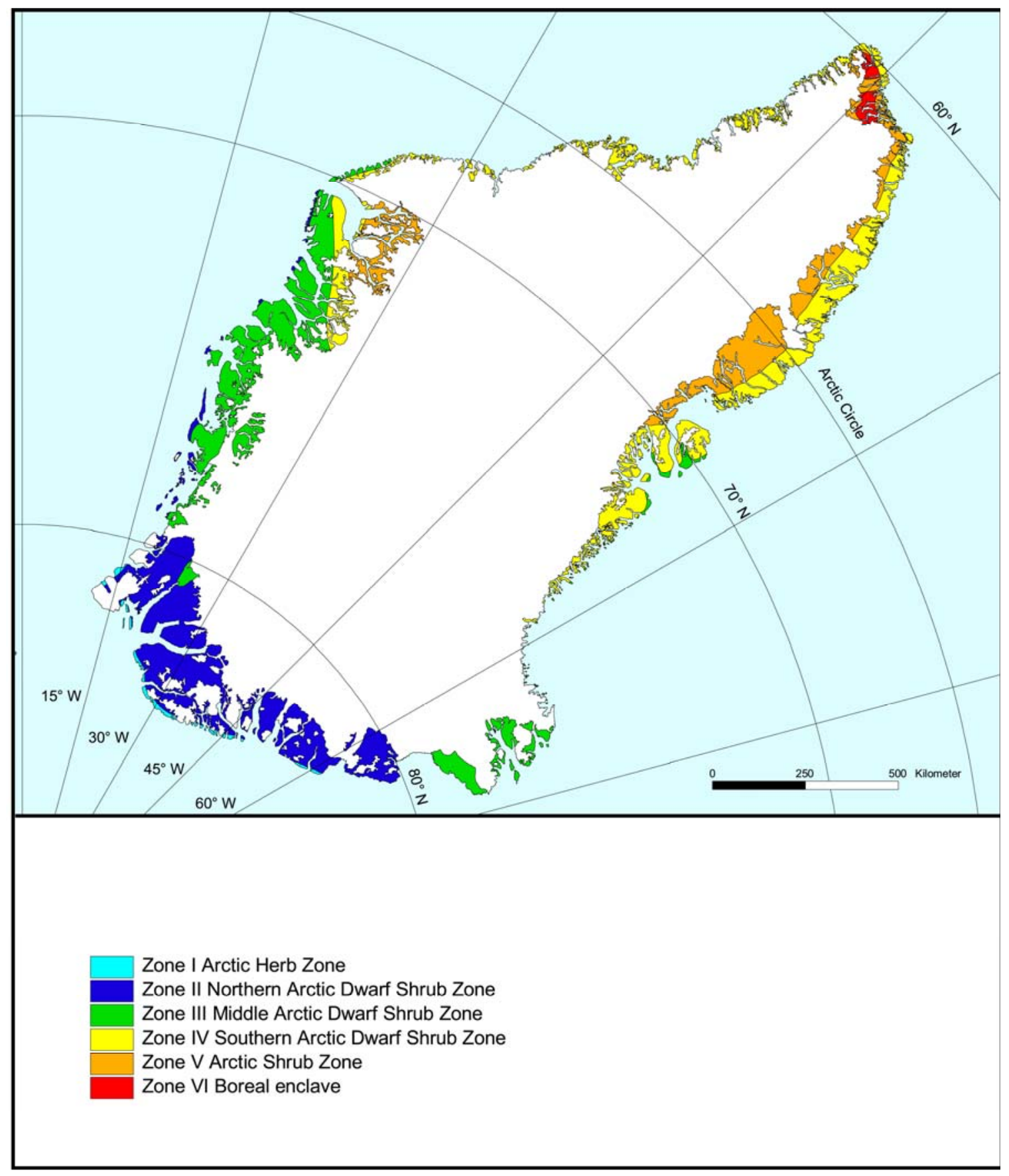

Figure 2. Bioclimatic zonation of Greenland. 


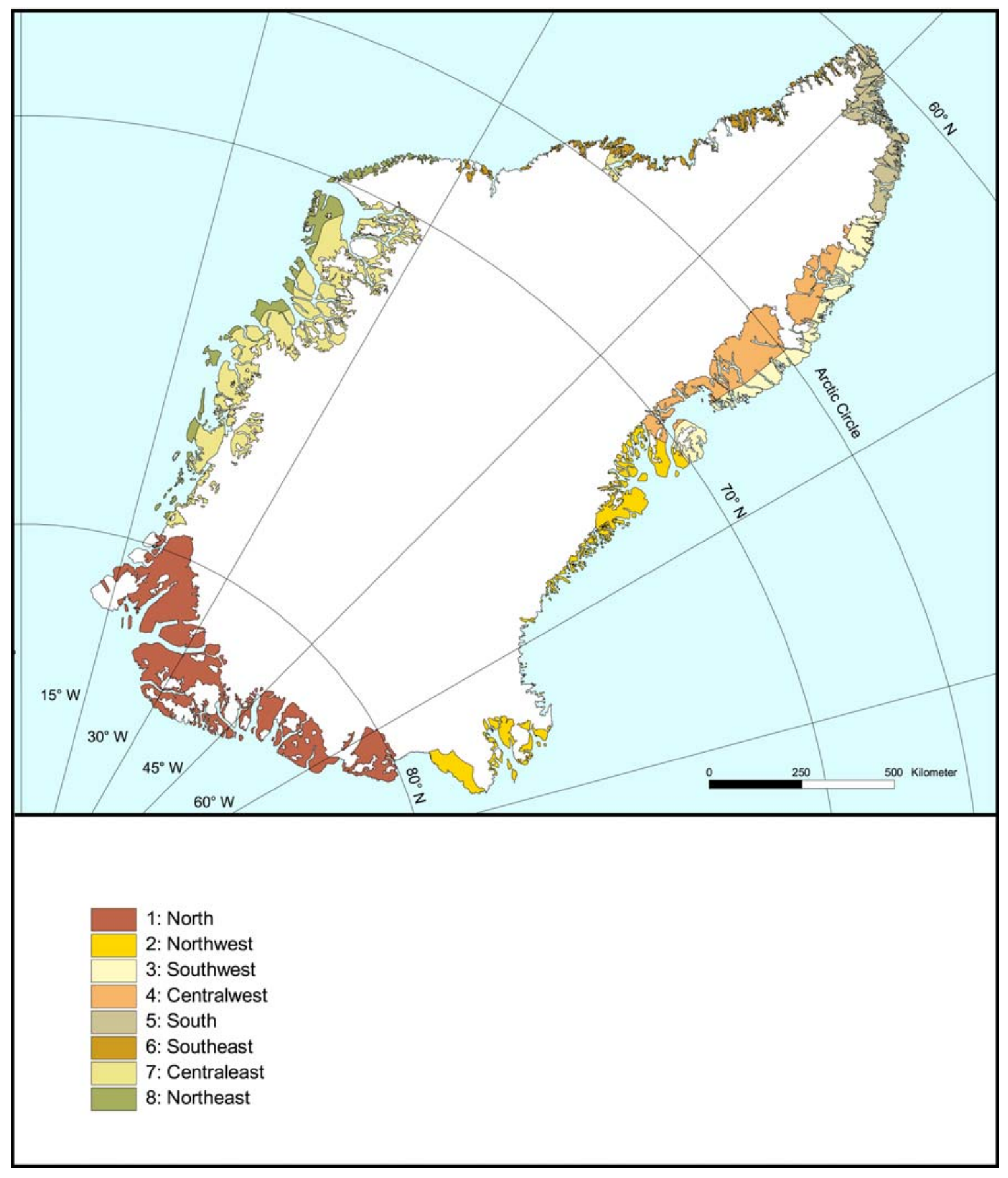

Figure 3. Floristic provinces of Greenland. 
Table 1. Codes for major syntaxa and plant communities in Greenland

\section{Code}

Syntaxon

010000 class

011000 order

011100 alliance

011101 association

011102 association

011103 vegetation type

020000 class

021000 order

021100 alliance

021101 association

021102 association

022000 order

022100 alliance

022101 association

022102 association

022103 association

022104 association

\section{0 class}

031000 order

031100 alliance

031101 association

031102 association

031103 association

031104 vegetation type

031105 vegetation type

031200 alliance

031201 vegetation type

031202 vegetation type

031203 sociation

031204 sociation

\section{Major syntaxa and plant communities in Greenland}

Asplenietea trichomanis Br.-BI. in Meier et Br.-BI. 1943

Potentilletalia caulescentis Br.-BI. ap. Br.-Bl. \& Jenny 1926

Cystopteridion fragilis Oberd. 1938

Cystopteridetum dickieanae Dierß. 1992

Sedo-Saxifragetum De Mol. 1976

Woodsia ilvensis sociations

\section{Thlaspietea rotundifolii Br.-BI. 1948}

Thlaspietalia rotundifolii Br.-Bl. ap. Br.-BI. \& Jenny 1926

Arenarion norvegicae Nordh. 1935

Saxifrago-Papaveretum radicatae prov. (Papaveretum dahlianae Hoffmann 1968 ?)

Papaveretum radicatae Dierßen 1992

Androsacetalia alpinae Br.-BI. ap. Br.-BI. \& Jenny 1926

Saxifrago stellaris-Oxyrion dignae Gjaerevoll 1950

Saxifrago-Oxyrietum dignae Gjaerevoll 1950

Chamaenerietum latifolii Böcher 1933

Deschampsietum alpinae (Sam. 1916) Nordh. 1943

Luzulo-Ranunculetum glacialis Nordh. 1943

\section{Caricetea curvulae Br.-BI. 1948}

Juncetalia trifidi Daniels 1994

Cladonio-Viscarion alpinae Daniels 1982

Cladonio-Viscarietum alpinae Daniels 1982

Luzulo-Thymetum drucei De Mol. 1976

Fimbriario-Sedetum annui De Mol. 1976

Chamaenerion angustifolium-Carex bigelowii community

Juncus trifidus-Salix callicarpaea community

\section{Carici-Juncion trifidi Nordh. (1936) 1943}

Juncus trifidus-Potentilla tridentata association

Juncus trifidus-Carex scirpoidea association

Juncus trifidus sociations

Luzula spicata sociations

\section{Vegetation and ecology}

\section{rock vegetation}

nonacidic-calcareous

nonacidic-calcareous

shaded, moist fissures

shallow soil on sunny rock ledges

dry, sunny fissures

\section{scree and debris vegetation}

calcareous

calcareous

polar desert of northernmost Greenland

enriched xeric-mesic stony substrates and blockfields

noncalcareous

noncalcareous

hygrophytic

riparian

hygrophytic, lateral water supply

chionophytic, mesic, gravelly fell-field

\section{acidophytic, dry sedge grass vegetation}

northern acidophytic, dry sedge vegetation

oceanic, psammophytic, slightly thermophytic, chionophytic

subxerophytic

subxerophytic, thermophytic

mesotrafent, xerophytic, thermophytic

mesophytic

xerophytic, sandy-gravelly instable soil

achionophytic, gravelly, stony substrate

subxerophytic, chomo-chalicophytic

subxerophytic, cryophytic

xerophytic, cryophytic

subxerophytic 


\section{0 class}

041000 order

041100 alliance

041101 association

041102 association

041103 vegetation type

041104 vegetation type

041105 vegetation type

041106 association

041200 alliance

041201 vegetation type

041202 vegetation type

041203 vegetation type

041204 vegetation type

\section{0 class}

051000 order

051100 alliance

051101 association

051102 association

051103 association

051104 association

051105 association

051106 vegetation type

\section{0 class}

061000 order

061100 alliance

061101 association

061102 vegetation type

061103 vegetation type

070000 class

071000 order

071100 alliance
Calamagrostietea purpurascentis prov.

Sedo-Poetalia glaucae De Mol. 1976

? Veronico-Poion glaucae Nord. 1943 (sensu Dierssen 1996)

Taraxaco-Poetum abbreviatae ass. prov.

Arabido holboellii-Caricetum supinae Dan. \& Freds. in Fredskild 1998

Arabis holboellii-Chamaenerion angustifolium sociation

Arctostaphylos uva ursi sociations

Saxifraga tricuspidata sociations

Saxifrago-Dryopteridetum fragantis

? Gentiano-Puccinellion deschampsioidis prov.

Puccinellia deschampsioides sociations

Sociations with Puccinellia deschampsioides and Braya linearis

Puccinellia angustata vegetation

Plantago maritima-Puccinellia deschampsioides community

\section{Carici rupestris-Kobresietea bellardii Ohba 1974}

Kobresio-Dryadetalia (Br.-BI. 1948) Ohba 1974

Dryadion integrifoliae Ohba ex Daniels 1982

Hypno-Cassiopetum tetragonae Lünterbusch 2002

Rhododendro-Vaccinietum microphyllii Daniels 1982

Carici-Dryadetum integrifoliae Daniels 1982

Lesquerello-Dryadetum integrifoliae Lünterbusch 2002

Cerastio-Festucetum brachyphyllae Dan. \& Freds. in Fredskild 1998

Kobresia myosuroides sociations

\section{Honckenyo-Elymetea arenariae R. Tx. 1966}

Honckenyo-Elymetalia arenariae R. Tx. 1966

Agropyro-Rumicion Nordh. 1940

Mertensietum maritimae (Nordh. 1940) Thann. 1981

Honckenya peploides sociation

Elymus mollis sociations

\section{Loiseleurio-Vaccinietea Eggler 1952}

Rhododendro-Vaccinietalia Br.-BI. ap. Br.-BI. \& Jenny 1926

Loiseleurio-Diapension (Br.-BI. et al. 1939) Daniels 1982 continental, nonacidic, xeric, grass/herb vegetation thermophytic

thermophytic

sheltered, enriched calcareous loess/loam

thermophytic, on shallow loam/loess

subxerophytic, thermophytic, stony-gravelly substrate

xerophytic, thermophytic, shallow loamy soil

xerophytic talus slide vegetation

thermophytic, talus slide vegetation

saline steppe vegetation on loess/silt

xerophytic, saline

thermophytic, subxerophytic, saline

xerophytic, oligohaline, often disturbed sites

mesophytic

nonacidic, achionophytic dwarf shrub/grass vegetation

nonacidic, achionophytic dwarf shrub/grass vegetation

nonacidic, achionophytic dwarf shrub/grass vegetation

mesophytic dwarf shrub heath, calcareous soil

submesic-hygric, nonacidic, base-rich soil

xerophytic, achionophytic

calcareous substrate

xerophytic, psammophytic herb/grass vegetation

cryoxerophytic

\section{dry coastal beach and sand dune vegetation}

dry coastal beach and sand dune vegetation

stony beach and nitrophytic sand dune vegetation

gravelly and stony beaches

sandy beaches

sandy dunes

dwarf shrub heath and low shrub on poor, acidic substrate dwarf shrub vegetation on poor acidic soil

achionophytic 
071101 association

071102 association

071103 association

071104 vegetation type

071200 alliance

071201 association

071202 association

071203 association

071204 vegetation type

\section{$\mathbf{0 8 0 0 0 0}$ class}

080001 association

081000 order

081100 alliance

081102 association

081103 association

081104 vegetation type

081105 vegetation type

081106 association

081200 alliance

081201 association

081202 association

081203 association

081204 vegetation type

081205 vegetation type

\section{0 class}

091000 order

091100 alliance

091101 association

091102 association

091103 association

091104 vegetation type

091105 association

091106 vegetation type

091107 vegetation type
Sphaerophoro-Vaccinietum microphylli Daniels 1982

Empetro-Betuletum nanae Nordh. 1943

Gymnomitrio-Loiseleurietum procumbentis Daniels 1982

\section{Salix uva ursi sociation}

\section{Phyllodoco-Vaccinion myrtilli Nordh. 1936}

Cassiopetum tetragonae (Böcher 1933) Daniels 1982

Phyllodoco-Salicetum callicarpaeae Böch.1933 em. Dan. 1982

Betuleto-Salicetum glaucae ass.prov

Empetrum hermaphroditum-Vaccinium microphyllum community

\section{Salicetea herbaceae Br.-BI 1947}

Oxyrio-Trisetetum Hadac (1946) 1986

Salicetalia herbaceae Br.-BI 1926

Saxifrago-Ranunculion nivalis Nordh. 1943 em. Dierß. 1984

Phippsietum algidae-concinnae Nordh. 1943

Luzulo-Salicetum herbaceae Dan. \& Freds. in Fredskild 1998

Saxifraga flagellaris-Luzula arctica community

Salix arctica community

Koenigio-Saginetum intermediae Dan. \& Freds. in Fredskild 1998

Salicion herbaceae Br.-BI. ap. Br.-BI. \& Jenny 1926

Cassiopo-Salicetum herbaceae (Fries 1913) Nordh. 1936

Ranunculo acris-Salicetum herbaceae Nordh. 1928

Cetrarietum delisei (Resv.-Holm.1920) Dahl 1957

Carex bigelowii community

Oxyria-Ranunculus pygmeus sociation

\section{Mulgedio-Aconitetea Hadac \& Klika in Klika \& Hadac 1944}

Adenostyletalia alliariae Br.-BI. 1931

Lactucion alpinae Nordh.1943

Festuco-Salicetum callicarpaeae Daniels 1982

Athyrietum distentifolii Nordh. 1928

Mniobryo-Archangelicetum archangelicae Nordh. 1943

Streptopus amplexifolius sociation

Taraxaco-Cystopteridetum fragilis De Mol. 1976

Alchemilla filicaulis-Lastraea dryopteris sociations

Alchemilla alpina sociations cryophytic, aerohygrophytic

(sub)continental, xerophytic, shallow substrate oceanic, temporarily moist-wet substrate,solifluction tolerant aerohygrophytic fell field vegetation chionophytic, mesophytic

meso-subhygrophytic, cryophytic xerophytic-hygrophytic, thermophytic continental low shrub vegetation oceanic, mesophytic

\section{snow bed vegetation}

northern, somewhat thermophytic, enriched soil snow bed vegetation

northern snow bed vegetation

wet late snow bed vegetation on loamy soil

moderate snow bed vegetation

late snow bed vegetation with trickling water

northern snow bed vegetation

wet, irrigated deflated soil

southern snow bed vegetation

poikilohydric late snow bed vegetation on poor soil

thermophytic, snow bed vegetation on richer soil tropohydrophytic, poikilohydric, in depressions

early snow bed vegetation on dry soil

skiophytic, enriched soil

\section{herb, tall forb, shrub vegetation on mesic-moist soil}

tall forb and shrub vegetation

tall forb and shrub vegetation

mesotrafent, meso-hygrophytic, sheltered sloping sites on coarse s poor stony substrates, hygrophytic, cryophytic

thermophytic, eutrafent, hygrophytic with permanent water supply nutrient-rich south facing talus slopes

hygophytic, rich soil along rocks, sheltered

hygrophytic, thermophytic, rich neutral soil

meso-subhygrophytic, rather chionophytic, shallow gravelly soil 
091108

vegetation type

\section{0 class}

101000 order

101100 alliance

101101 association

101102 association

\section{0 class}

111000 order

111100 alliance

111101 association

111102 association

111103 association

111104 association

111200 alliance

111201 association

\section{0 class}

121000 order

121100 alliance

121101 association

122000 order

122100 alliance

122101 vegetation type

122102 vegetation type

122103 vegetation type

122104 vegetation type

\section{0 class}

131000 order

131100 alliance

131101 association

131102 association

131103 association

131104 association
Alchemilla glomerulans sociations

Isoeto-Nanojuncetea Br.-BI. \& Tx. 1943 ex Westh. et. al. 1946 Nanocyperetalia Klika 1935

\section{Nanocyperion Koch ex Libbert 1932}

Drepanoclado-Ranunculetum hyperborei Hadac 1989

Koenigio-Sedetum villosi Sorensen 1942

Montio-Cardaminetea Br.-BI. \& R.Tx. 1943 ex Klika \& Hadac 1944 Montio-Cardaminetalia amarae (Br.-Bl. 1925) Pawlowski et al. 1928

Cardamino-Montion Br.-BI. 1926

Mniobryo-Epilobietum hornemannii Nordh. 1943

Philonoto-Saxifragetum stellaris Nordh. 1943

Scapanietum uliginosae (Sjörs 1946) Dahl 1957

Calliergono-Bryetum cryophili Hofm. 1968

Cratoneurion commutati Koch 1928

Catoscopio-Saxifragetum aizoidis Nordh. (1936) 1943

Oxycocco-Sphagnetea Br.-BI. \& R.Tx. 1943

Sphagnetalia magellanici Kästner \& Flößner 1933

Oxycocco-Empetrion hermaphroditi Nordh. ex Neuhäusl 1969

Empetro-Spagnetum fusci Du Rietz 1921 em. Dierß. 1980

Ledo decumbentis-Betuletalia glandulosae Rivas-Martinez et al. 1999

Salici pulchrae-Betulion glandulosae Rivas-Martinez et al. 1999?

Calamagrostis lapponica sociations

Ledum decumbens-Betula nana sociations

Betula nana sociations

Vaccinium uliginosum microphyllum sociations

Scheuchzerio-Caricetea nigrae (Nordh. 1936) R.Tx.1937

Caricetalia nigrae (Koch 1926) Nordh. 1936 em. Br.-Bl. 1949

Caricion nigrae Koch 1926 em. Klika 1934

Eriophoretum scheuchzeri Fries 1913

Caricetum rariflorae Fries 1913

Calliergo-Caricetum saxatilis Nordh. 1928 em. Dierßen 1982

Menyantho-Sphagnetum teretis Wayren 1926 strongly photophytic, hygophytic, thermophytic, oligo-mesotrafent

small rush vegetation on temporarily moist soil

small rush vegetation on temporarily moist soil small rush vegetation on temporarily moist soil

loamy soil along oligotrophic lakes, springs, streams in sheltered, loamy, wet soil in the mountains

\section{oligotrafent spring and flush vegetation}

oligotrafent spring and flush vegetation

noncalcareous, eustatic spring vegetation weakly acidophytic, cryophytic, mesotrafent neutrophytic, less cryophytic, rich hygric-hydric, skiotolerant, thermophily variable along seepage runnels and trickling streams nonacidic, calcareous eustatic spring vegetation rich, calcareous-basic-neutric, hygric-hydric, chionophytic

bog and acidic tussock tundra vegetation

raised bogs, acidic tussock tundra

ombrotrafent, continental raised bog vegetation

ombrotrophic, strongly acidic hummocks

continental ombro-minerotrafent tussock tundra vegetation continental ombro-minerotrafent tussock tundra vegetation hygrophytic, eutrafent

meso-hygrophytic, mesotrafent

mesophytic

xero-mesopühytic

\section{sedge grass and dwarf shrub fen vegetation}

acidophytic, poor fen vegetation acidophytic, poor fen vegetation

hygric, acidic, alluvial substrate

(sub)hygric, peaty margins of lakes and ponds

(sub)hygric, nonacidic, mineral soil

hygrophytic mesotrafent fen vegetation 
131105 association

131106 association

Pediculari-Vaccinietum Daniels 1982

131107 vegetation type

132000 order

132200 alliance

132201 association

132202 association

132203 association

132204 association

132205 association

132206 association

132207 association

132208 association

132209 association

132210 association

132211 association

132212 association

132213 vegetation type

132214 vegetation type

132215 vegetation type

\section{0 class}

141000 order

141100 alliance

141101 association

141102 association

141200 alliance

141201 association

\section{0 class}

151000 order

151100 alliance

151101 association

151102 association

151103 association

151200 alliance

Scirpus caespitosus sociations

Caricetalia davallianae Br.-BI. 1949

Caricetum stantis auct.

Caricetum holostomae Dierßen 1996

Caricetum gynocratis Dierßen 1996

Carex maritma sociations

Calamagrostis neglecta sociation

Eleocharis quinqueflorus sociations

\section{Juncetea maritimi Br.-BI. 1931}

Littorelletalia uniflorae W. Koch 1926

Subulario-Juncetum subtilis prov.

Littorellion uniflorae Koch 1926
Calamagrostio-Ditrichetum De Mol. 1976

Caricion atrofusco-saxatilis Klika 1934

Equiseto-Caricetum rariflorae De Mol. 1976

Saxifrago-Kobresietum simpliciusculae Dan. \& Freds. in Fredskild 1998

Arctagrostio-Eriophoretum tristis Dan. \& Freds. in Fredskild 1998

Juncetum arctici (Gams 1927) Bressoud 1989

Pohlio-Caricetum rufinae De Mol. 1976

Caricetum microglochinis Nordh. 1928

Junco-Caricetum bicoloris Doyle 1952

Oncophoro-Caricetum norvegicae Dierßen 1982

Triglochini-Juncetum triglumis (Kalela 1939) Dierßen 1982

Glauco-Puccinellietalia Beeft. \& Westh. 1962

Puccinellion phryganodis Hadac 1946

Puccinellietum phryganodis Hadac 1946

Caricetum subspathaceae Hadac 1946 em. De Mol. 1974

Armerion maritimae Br.-BI. \& de Leeuw 1936

Festuco-Caricetum glareosae Nordh. 1954

Littorelletea uniflorae Br.-BI. \& R.Tx. 1943 ex Westh. \& al. 1946

Subularion aquaticae (Sorensen 1942) Hadac 1971

Callitricho-Subularietum aquaticae prov.

Ranunculo-Alopecuretum aequalis prov. mesotrafent, sloping fen with laterally moving ground water fluvioglacial plains; hygro-tropohydrophytic, neutrophytic subhygric, acidic peaty soils

rich fen vegetation

rich fen vegetation

subhygric-hydric margins of shallow ponds/lakes

hygro-tropohydric rich calcareous soil

mesic-hygric on rich calcareous soil

hygric with lateral water supply, sloping sites

hygric, alluvial mineral substrate

hygric-tropohydric, rich noncalcareous alluvial substrate hygric-tropohydric, calcareous loamy soil

hygric-tropohydric, rich calcareous alluvial substrates hygric, poikilohydric, coarse stony substrate, oozing water subhygric, peaty soil

mesic, peaty soil

poikilohydric, gravelly wet substrate by spring/meltwater sandy plains in river valleys

meso-hygrophytic, mesotrafent along ponds

suboligohalin soil

\section{coastal salt marsh vegetation}

coastal salt marsh vegetation

hydric, loamy, lower saline habitats

hydric, loamy, saline habitats

hygric, saline habitats

mesic-hygric, sandy, upper less saline habitats

mesic-hygric, sandy, weakly saline habitats

\section{oligo-mesotrafent amphiphytic vegetation}

oligo-mesotrafent amphiphytic vegetation acidic-neutral, muddy bottoms of temporary dry ponds strongly oligotrafent

mesotrafent, along the shore of deeper temporary ponds tropohydric on sand at the edge of ponds and lakes oligotrafent, tropohydrophytic 
151201 association

151202 vegetation type

151203 vegetation type

151300 alliance

151301 association

\section{0 class}

160001 vegetation type

161000 order

161001 association

\section{0 class}

170001 vegetation type

171000 order

171100 alliance

171101 vegetation type

171102 vegetation type

171103 vegetation type

\section{0 class}

181000 order

181100 alliance

181101 association

181102 association
Isoetum echinosporae Koch 1926 em. Dierßen 1975

Myriophyllum alterniflorum community

Ranunculus reptans community

Eleocharition acicularis Jouanne 1925

Eleocharitetum acicularis Koch 1926

\section{Phragmitetea Tx. \& Prsg. 1942}

Calamagrostis langsdorfii community

Phragmitetalia australis Koch 1926

Hippuridetum vulgaris Rübel 1912

\section{Utricularietea d. Hartog \& Segal 1964 em. Pietsch 1965}

Pleuropogon sabinei-community

Utricularietalia intermedio-minoris Pietsch 1965

Sphagno-Utricularion Müller \& Görs 1960

Sparganium hyperboreum sociations

Sparganium angustifolium vegetation

Utricularia minor vegetation

Potamogetonetea pectinati R.Tx. \& Prsg. 1942

Potamogetonetalia pectinati Koch 1926

Potamogetonion pectinati (Koch 1926) Görs 1986

Potamogetonetum filiformis Koch 1928

Ranunculetum confervoidis prov.

181103 vegetation type Potamogeton alpinus tenuifolius sociations

oligotrafent, in lakes and ponds

oligo-mesotrafent, in lakes

oligo-mesotrafent, in lakes and ponds

mesotrafent, tropohydric

oligo-eutrafent, tropohydric at edge of lakes, ponds and streams

swamp vegetation of tall sedges, grasses and herbs

marsh vegetation, mesic-hygric, on basic soil

aquatic tall sedge, grass and herb vegetation

oligo-eutrafent along pond and lake margins

\section{oligo-dystrafent aquatic vegetation}

oligo-mesotrafent,hydric, shallow ponds and lakes oligo-dystrafent aquatic vegetation

acidophytic, dystrafent

oligo-mesotrafent, lowland ponds, puddles, lakes, streams oligo-mesotrafent, lowland lakes and ponds

mesotrafent, submerged in lowland pools and fens

with oozing water

aquatic vegetation

aquatic vegetation

aquatic vegetation

eutrafent, in many types of waters

oligo-eutrafent, in lakes, ponds, brooks

mesotrafent, in lakes, ponds and rivers 


\title{
THE POSITION OF ICELAND IN THE SYSTEM USED IN THE CAVM MAPPING
}

\author{
Eythór Einarsson \\ Icelandic Institute of Natural History \\ Hilemmur 3, Box 5320, Reykjavik, IS-125, Iceland \\ E-mail: eythor@ni.is
}

The vegetation position of various areas and countries, including Iceland, has often been discussed within the CAVM team as part of the vegetation of the arctic area and its classification into zones and subzones. In spite of the fact that Iceland is just a tiny part of this vast area, its rather complex situation is nevertheless of a certain interest. Maritime, alpine, and arctic environmental factors are mixed together in a complex way to form the background for Iceland's vegetation, together with its flora, volcanic soils, and climate.

I have been of the same opinion as many authors who have dealt with the plant geographic position of Iceland that the tundra vegetation of the highlands of Iceland should be classified as Arctic or ArcticAlpine, whereas most of the lowlands belong to the Boreal zone, mainly the North Boreal subzone (Davídsson, 1945; Steindórsson, 1964; and Thórhallsdóttir, 1997). In parts of North-Iceland, however, this highland-type vegetation extends down to the coasts and becomes Arctic, with no clear limits between the Alpine and Arctic parts. The vegetation is mostly characterized by low-shrubs and dwarf-shrubs, equivalent to that of the Southern hypoarctic tundra (cf. B.A. Yurtsev, 1994), but in extensive tracts of land with desert-like vegetation due to erosion. In the boreal areas, the natural vegetation of the lowlands is birch forest of Betula pubescens (including B. tortuosa), but a large part has been destroyed by erosion following serious overexploitation. On the map of Iceland (by E. Einarsson, G.M. Gudbergsson, and L. Paahlsson), which is a part of the map of the Physical Geographical Regions of the Nordic Countries and mainly based on the vegetation and included in Naturgeografisk regionindeling av Norden, this same understanding of the vegetation of Iceland is followed. That is also the case with the recent vegetation map of Iceland (Gudjónsson and Gíslason, 1998). In the literature, some authors (Hustich, 1960 and 1970) have classified the birch forest area as a separate zone, the Sub-Arctic zone (cf. also Bluthgen, 1970) where the definitions and boundaries of this zone are discussed further.

Some members of the CAVM mapping team, e.g., A. Elvebakk (cf. A. Elvebakk, 1999), are of the opinion that the treelessness of the Central Highlands of Iceland is caused by alpine rather than arctic conditions; therefore the Central Highlands should be separated from the Arctic northernmost lowlands of Iceland and regarded as an alpine part of the Boreal zone. To be consistent in the CAVM mapping of the Circumpolar Arctic vegetation and follow the same definitions in the North Atlantic as in the North Pacific, only these northernmost parts of Iceland should be classified as Arctic on the basis of climate, floristic, and vegetation evidence, because of a lack of forests in the natural vegetation.

According to the Icelandic Sagas written in the 13th century, and particularly the Book of Icelanders (Íslendingabók) written about 1130 by Ari Thorgilsson the Wise, the lowlands of Iceland were covered with woody (sic.) vegetation at the time of the settlement of Iceland by man, around 870-930. This statement has been confirmed by pollen analysis (Einarsson, 1961 and 1962; Hallsdóttir, 1995; and Kristinsson, 1995). At that time, the climate of Iceland and all North Europe was milder than it became later, especially during the cold 17th-19th centuries that were known in Iceland as "the little Ice-age." Most of this woody vegetation (forests and scrub) was destroyed by severe over-exploitation by man, made particularly serious by the deteriorating climate and followed by extensive soil erosion.

The immense human influence on the vegetation of Iceland during the last millennium, together with the soil conditions and climate of today (Einarsson, 1984), was used while preparing the map of the natural vegetation of Iceland (within the team work Map of the Natural Vegetation of Europe), as reported by E. Einarsson at the CAVM workshop in Anchorage in 1998. The result, however, became a map that in all main lines is in harmony with the opinions of other Icelandic authors on the classification of the vegetation of Iceland mentioned earlier.

In 2000, E. Einarsson and E. Gíslason compiled an overview map of the vegetation of Iceland at the time of settlement; i.e., the period 870-930, really a hypothetical vegetation map of that time. The map was based on all available data, literature, unpublished data and information from various scientists, such as on 
the climate, particularly the summer climate, landscape, altitudinal vegetation boundaries, information about soil remnants found at several places in the Central Highlands, and place names. Owing to the wide meaning of the Icelandic word "skógur" (forest), which covers all woody vegetation taller than the average height of a grown man and some-times not even taller than about $1 \mathrm{~m}$, all vegetation dominated by birch (Betula pubescens) had to be classified as birch scrub and/or forests, as no clear lines could be drawn between them. Thus the authors are aware that even at the time of settlement some parts of the North Icelandic lowlands were covered only with scrub and not by real forests.

Floristically, Iceland is a mixture of the Arctic and the Boreal zones. Using E. Hulten's distribution groups of the Nordic flora, defined in his Atlas of the Distributions of Plants in the Nordic Countries (Hulten, 1950), about half of the approximately 485 natural and naturalized species of vascular plants now growing wild in Iceland have a boreal total distribution, whereas about one-third have an arctic-alpine total distribution, in most cases a low-arctic distribution (Einarsson, 1963 and 1997; and Kristinsson, 1997). About 85 of the 485 species were probably introduced by man (Steindórsson, 1964) and may be regarded as archaeophytes as they were most likely brought to Iceland centuries ago. These species all have a boreal total distribution, and some of them have a very limited distribution in Iceland and only play a minor role in the Icelandic vegetation; some of them have only found suitable places to grow in warm soils in thermal areas. Leaving the archaeophytes out the boreal part, the remaining 400 species are reduced to about 40 percent of the Icelandic flora, whereas the arctic-alpine species make up about 41 percent, or a larger part than the boreal ones. The percentage of boreal species is also considerably higher in Southern Iceland than in Northern Iceland. As a part of the preparatory work for the Panarctic Flora Project, H. Kristinsson (pers. inform.) has found that the northernmost quadrates in the $10 \times 10-\mathrm{km}$ grid system used for work on the distribution of species in Iceland have a considerably higher number of arctic than boreal species of vascular plants. See also a map of the subdivision of the Arctic territory in Elvebakk and others (1999).

In the Floristic regions of the world, Takhtajan (1986) places the whole of Iceland in the Arctic Province, even if such a broad understanding of the Arctic phytochorion is not acceptable to everyone. Finding it difficult to delimit the true arctic territories of Greenland and Iceland from the boreal-oceanic ones, he considers it better to keep them within the Arctic Province as separate subprovinces.

The present author is of the opinion that the use of floristics alone as a criterion for the definition of the Arctic zone, instead of the physiognomy of the vegetation (vegetation beyond the natural tree line), is not sufficient. Both criteria should be used, especially as the physiognomy is used as a criterion for the definition of the Arctic sub-zones. Many authors have made observations on the flora and vegetation of the northernmost parts of Iceland and published their results (Steindórsson, 1936 and 1950; I. Davídsson, 1937; Löve, 1948; Einarsson, 1975; Hallgrímsson, 1976; Gudbergsson, 1992; Kristinsson, 1992; and Kristinsson and Gudjónsson, 2000). Further information has been gained from botanists and other people with a thorough knowledge of this area, for example the bryologist Bergthór Jóhannsson (personal information).

Additionally, the author has made use of unpublished maps (courtesy of Th. H. Jónsson and H.H. Hansen) of the thermally potential species limit and treeline of birch in Iceland, derived from the growing season temperatures and data on the empirical species limit in North-Iceland, as well as corresponding work on the birch tree-line in Norway (Aas, 1964).

Bearing the previously mentioned points in mind, the author accepts the proposal of the CAVM working group to regard only the northernmost parts of Iceland as a vegetation part of the true Arctic zone. That is also done to ensure consistency between the classification used in the North Atlantic and the North Pacific. The boundary of the Arctic zone in Iceland is shown on the map in figure 1. It is based on floristics and the physiognomy of the natural vegetation considered as corresponding to the climatic and soil conditions of present times. Regard has also been paid to the data on the potential species limit and tree line of birch in Iceland mentioned earlier, which lead to results corresponding in most aspects with the boundary line on figure 1 . In a couple of places, however, these data set the boundary line somewhat further south. This true Arctic part of Iceland belongs to the Tundra Subzone 4, low-shrub subzone (locally with a resemblance to Subzone 3) as proposed and defined by Walker (2000), or Subzone 5 (locally with resemblance to Subzone 4), since it has now been decided to use five zones instead of four. The tundra regions of the Central Highlands of Iceland may therefore be regarded as alpine tundra and classified accordingly; for example, as Oro-Arctic in accordance with the Finnish definition.

The author is very grateful to Gudmundur Gudjónsson, Thorbergur Jónsson, Bergthór Jóhannsson, and Hördur Kristinsson for fruitful discussion, important advice, and information. 


\section{References}

Aas, B., 1964, Björke-og Barskogsgrensen i Norge (Birch and conifer tree lines in Norway): University of Oslo, M.S. Thesis.

Bluthgen, J., 1970, Problems of definition and geographical differences of the Subarctic with special regard to northern Europe, Proceedings: Paris, Unesco, Helsinki Symposium on the ecology of the subarctic regions, p. 11-31.

Davídsson, l., 1937, Gródurrannsóknir á Hesreyri og í Adalvík: Náttúrufraedingurinn, v. 7, p. 15-24.

Davídsson, I., 1945, Staða Íslands í gródurbeltaskipun jardarinnar: Náttúrufrædingurinn, v.15, p. 72-86.

Einarsson, E., 1963, The elements and affinities of the Icelandic flora, in, Áskell Löve and Doris Löve, eds., North Atlantic Biota and their History: Oxford, Pergamon Press, p. 297-302.

Einarsson, E. (1975) Gródurfar á Hornströndum og í Jökulfjördum: Náttúrufraedingurinn, v. 45, p. 43-52.

Einarsson, E., 1997, Adfluttar plöntur á Íslandi, in Audur Ottesen, ed., Nýgraedingar i flórunni: Félag gardyrkjumanna. Reykjavík, p. 11-15.

Einarsson, E., Gudbergsson, G. M., and Paahlsson, L., 1984, Map of Iceland, a part of a map of Physical Geographical Regions of the Nordic Countries: Naturhistorisk Regionindeling av Norden, Nordiska Ministerraadet.

Einarsson, M. Á., 1984, Climate of Iceland, in van Loon, H., ed., World Survey of Climatology: Amsterdam, Elsevier, v. 15, p. 673-697.

Einarsson, Th., 1961, Pollenanalytische Untersuchungen zur spat-und postglazialen Klimagesichte Islands: Sonderveröffentlichungen des Geologischen Institutes der Universitat Köln, v. 6., 52 pp.

Einarsson, Th., 1962, Vitnisburdur frjógreiningar um gródur, veduefar og landnám á Íslandi: Saga, p. 442-468.

Elvebakk, A., 1999, Bioclimatic delimitation and subdivision of the Arctic, in Nordal, I. and V. Yu. Razzhivin, eds., The species concept in the High North-A panarctic Flora Initiative: Det Norske Videnskaps-Akademi. I. Mat.-naturv. Klasse Skrifter Ny Serie, v. 38, p. 81-112.

Elvebakk, A., Elven, R., and Razzhivin, V. Yu, 1999, Delimitation, zonal and sectoral subdivision for the Panarctic Flora Project, in Nordal, I. and V. Yu. Razzhivin, eds., The species concept in the High North-A panarctic Flora Initiative: Det Norske Videnskaps-Akademi. I. Mat.-naturv. Klasse Skrifter Ny Serie, v. 38, p. 375-386.

Gudbergsson, G., 1992, Skógar í Skagafirdi: Skógraektarritid, p. 74-85.

Gudjónsson, G. and Gíslason, E., 1998, Vegetation Map of Iceland General Overview: Icelandic Institute of Natural History, Reykjavík.

Hallgrímsson, H., 1976, Flóra Flateyjarskaga: Náttúrugripasafnid á Akureyri, Fjölrit Nr. 6, Akureyri, 44 pp.

Hallsdóttir, M., 1995, On the pre-settlement history of Icelandic vegetation: Búvísindi. Icel. Agricult. Science, no. 9, p. 1729.

Hulten, E., 1950, Atlas of the Distribution of Vascular Plants in N.W. Europe: Generalstabens Litogeografiska Anstalts Förlag, Stockholm, Sweden, $512 \mathrm{pp}$.

Hustich, I., 1960, Plant geographical regions: A geography of Norden, 0slo, p. 54-62.

Hustich, I., 1970, On the study of the ecology of subarctic vegetation: Ecology of the subarctic regions,: Paris, Unesco, Helsinki Symposium on the ecology of the subarctic regions, p. 235-240.

Kristinsson, H., 1992, Gönguferd um Hédinsfjörd: Ársrit Útivistar, v. 18, p. 27-39.

Kristinsson, H., 1995, Post-settlement history of Icelandic forests: Búvísindi. Icel. Agricult. Science, no. 9, p. 31-35.

Kristinsson, H., 1997, Uppruni íslensku flórunnar, in, Audur Ottesen, ed., Nýgraedingar i flórunni: Félag gardyrkjumanna. Reykjavík, p. 6-9.

Kristinsson, H. and Gudjónsson, G., 2000, Gródur vid fyrirhugada veglínu milli Siglufjardar og Ólafsfjardar: Náttúrufrædistofnun Íslands Akureyri, 18 pp.

Löve, Á., 1948, Gródur nyrzt á Hornströndum: Náttúrufraedingurinn, v. 18, p. 97-112.

Steindórsson, S., 1936, Om Vegetationen pa Melrakkasljetta i det nordöstlige Island: Botanisk Tidsskrift, Bd. 43, v. 6, p. 436-483.

Steindórsson, S., 1946, Vestfirdir l.: Gródur, Reykjavík, 92 pp.

Steindórsson, S., 1950, Skógar í Eyjafirdi: Drög til sögu theirra. Ársrit Skógraektarfélags Íslands, p. 49-80.

Steindórsson, S., 1964, Gródur á Íslandi: Almenna bókafélagið, Reykjavík, 186 pp. 
Takhtajan, A., 1986, Floristic Regions of the World, Translated from Russian by T.J. Crovello: Berkeley, University of California Press, 522 pp.

Thorgilsson, Ari the Wise (written about 1130) Íslendingabók (Book of Icelanders).

Thórhallsdóttir, Th. E., 1997, Tundra Ecosystems of Iceland, in Wielgolaski, F.E., ed., Ecosystems of the World 3, Polar and Alpine, Tundra. Chapter 5: Amsterdam, Elsevier, p. 85-96.

Walker, D. A., 2000, Hierarchical subdivision of Arctic tundra based on vegetation response to climate, parent material and topography: Global Change Biology, v. 6 (Suppl.1), p. 19-34.

Yurtsev, B. A., 1994, Floristic division of the Arctic: Journal of Vegetation Science, v. 5, p. 765-766. 


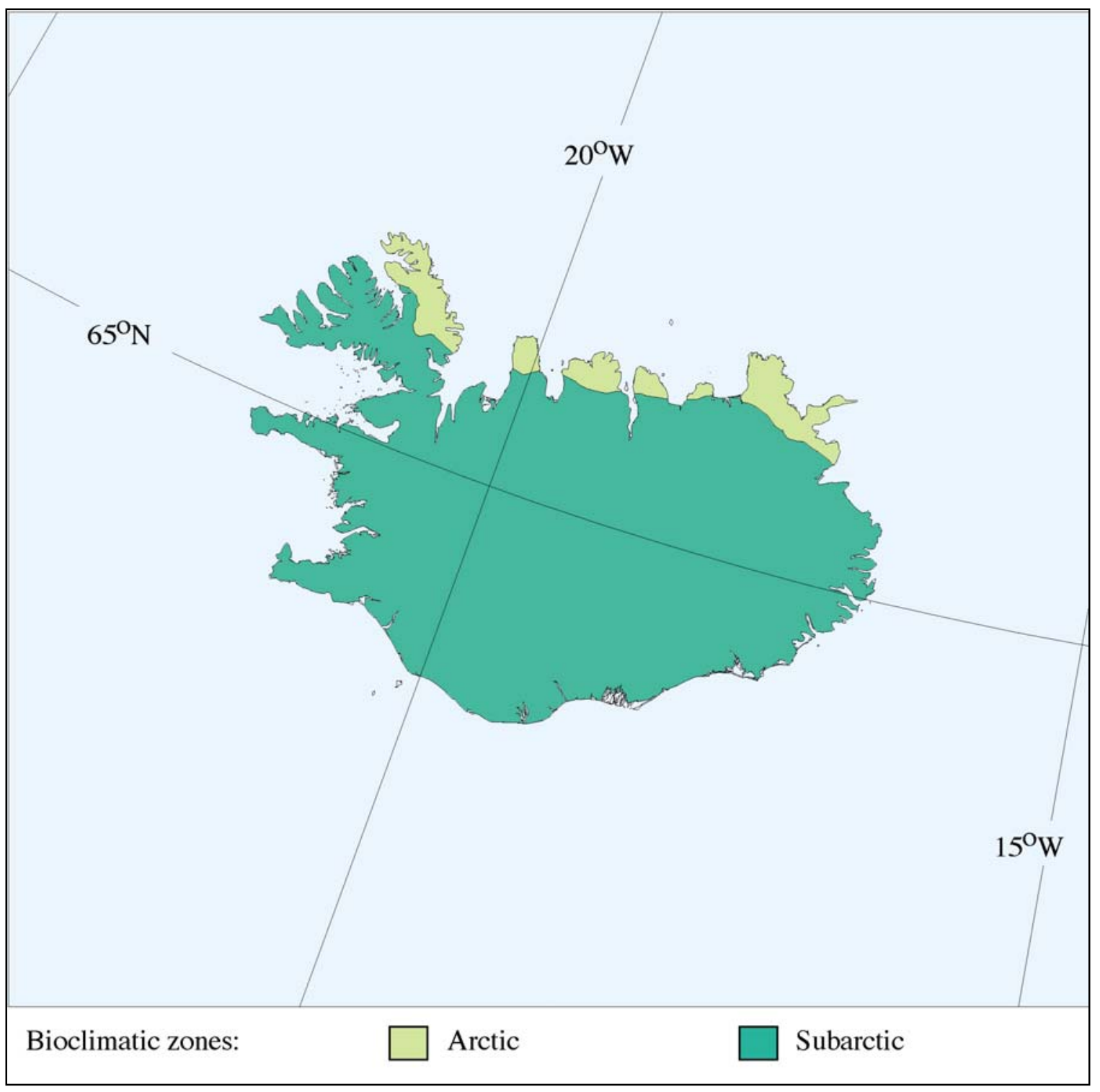

Figure 1. The boundary of the true Arctic Zone in Iceland. 


\title{
PERCENTAGE OF LAKE COVER IN THE RUSSIAN ARCTIC
}

\author{
Galina V. Ananjeva (Malkova), Olga E. Ponomarjeva \\ Earth Cryosphere Institute \\ SB RAS, 30/6 Vavilov Str., \\ Moscow, 119991, Russia \\ E-mail: emelnikov@mtu-net.ru
}

The map of lake cover is one of the auxiliary maps in the CAVM project. No similar published map for the Russian Arctic territory now exists. In 1999, at the first stage of the CAVM project, we decided to use a method of elementary quadrates proposed by Beletskaja (1988). This method is based on counting the percentage of lakes within quadrates. The Western Siberia and the Taymyr Peninsula were analyzed in this way. As a second step, we completed a lake cover map of the whole Russian Arctic. In drawing the lake cover map, the existing CAVM ARC/INFO files for coastline, hydrological network ("hydrology"), and "forest boundary" for the Russian Arctic were used. The first two files were used without any changes. The "forest boundary" layer was changed somewhat while creating the landscape maps. Only the arcs marking lake boundaries were copied from the hydrology layer. Then the arcs were examined and assembled, and the lake polygons were built. Thus, we created a "lake" layer, where each lake is represented as an individual polygon. The original file included only lakes greater than $1 \mathrm{~km}$ in diameter, and thus our map includes only lakes of such size and larger. A table containing information on the lakes was created, including the coordinates and area of each lake. The table also contains lake names, taken from topographical maps of Russia at a scale of 1:1,000,000.

In the territory of the Russian Arctic there are more than 15,000 lakes larger than $1 \mathrm{~km}$ in diameter. The largest of themthe Taymyr Lakehas an area of $4,630 \mathrm{~km}^{2}$. Dozens of lakes larger than $50 \mathrm{~km}^{2}$ can be found on the Yamal and Gydan Peninsulas, and also in East Siberia.

For calculating lake cover using the elementary squares method (Beletskaya, 1988), a polygonal computer layer "grid" for all of the Russian Arctic was created. We used a cell grid of 20 x $20 \mathrm{~km}$ (400 $\mathrm{km}^{2}$ ) in our calculations and changed the square only along the irregular borders of the mapped area near the sea coastline and along the "forest boundary. " Percentage cover of lakes was derived using an overlay operation with the two layers, "lake" and "grid. " For each quadrate of the pattern we calculated its area, the total area of lakes within a quadrate, and the percentage of lake cover. The information table of the resulting overlay layer was created automatically. The table contains the exact value of the percentage of lakes in each cell of the "grid." The lake map used the following intervals: $<2$ percent; 2-10 percent, 10-25 percent, 25-50 percent, > 50 percent (Walker 1998).

Lake cover in the Russian Arctic territory is very nonuniform (fig. 1). Maximum lake cover is characteristic of sites with numerous large and middle-size lakes, such as some zones in the Malozemelskaya tundra, in the Varandey area (European Russia), on the central and southern Yamal Peninsula, in the Khatanga valley (Taymyr), and in the Lena Delta (Yakutia). The territory of Yakutia has essentially high lake cover. It is usually more than 2 percent, and often 10-25 percent (fig. 1). Yakutia consists of level depositional plains formed by frozen icy sediments, subject to thermokarst. In contrast, Chukotka has minimum lake cover because it is a mountainous erosional region. 


\section{Literature}

Beletskaya, N.P., 1988, Reljef Zapadno-Cibirskoy ravniny [The relief of the Western Siberia plain]: Nauka, 192 pp.

Walker D.A., 1998, An integrated vegetation mapping approach for the Circumpolar Arctic Vegetation Map, in Markon, C.J., and Walker, D.A., eds., Proceedings of the Third International Circumpolar Arctic Vegetation Mapping Workshop, Anchorage, AK, 3-7 June, 1998: U.S. Geological Survey Open-File Report 99-551. 


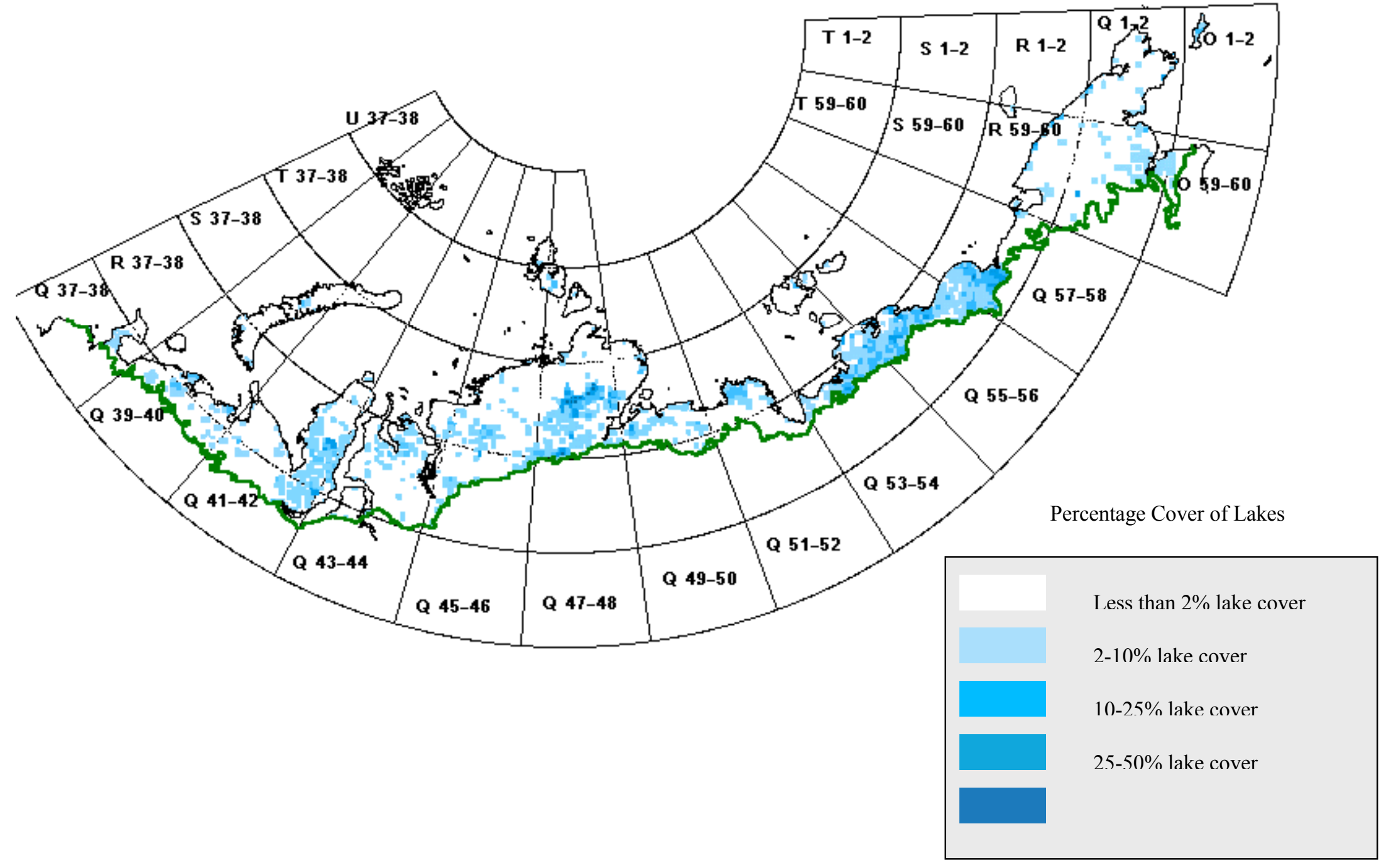

Figure 1. Percentage cover of lakes in Yakutia. 


\title{
LANDSCAPE MAP OF THE RUSSIAN ARCTIC
}

\author{
Dmitriy S. Drozdov, Galina V. Ananjeva (Malkova), and \\ Yury V. Korostelev \\ Earth Cryosphere Institute \\ SB RAS, 30/8 Vavilov Str., \\ Moscow, 119991, Russia \\ E-mail: emelnikov@mtu-net.ru
}

The landscape map of the Russian Arctic (1:4,000,000-scale) is a general source-map used in the subsequent production of the CAVM Vegetation map (Walker, 1998). It includes information on altitudinal-longitudinal and natural-climatic zoning, on genetic and lithological complexes of both soils and rocks, on soil salinity, and on acidity of rocks. In creating the landscape map, we used cartographic materials (including rivers, lakes, and coastline) of appropriate or larger scale which were based on space photoimages projected into a circumpolar Lambert projection map (Gudilin and Komarov, 1978).

The landscape map of the Russian Arctic (1:4,000,000-scale) was created using some of the authors' own materials collected from field research in various north regions, but also using different published thematic maps. The following maps were consulted:

Belov, V.A., 1990, Vegetation map of USSR at scale 1:4 000 000: GUGK [State committee on geodes and mapping of the USSR], Moscow.

Churinov, M.V, 1972, The Engineering-geological map of the USSR at scale 1:2 500 000, GUGK, Moscow.

Ganeschin, G.S., 1976, Map of Quarternary (surface) geology at scale 1:2 500 000, GUGK, Moscow.

Gudilin, I.S., 1980, Landscape map of USSR at scale 1:2 500 000, GUGK, Moscow.

Melnikov, E.S., 1999, Landscape map of Russia permafrost at scale 1:4 000 000, Earth Cryosphere Institute SB RAS, Moscow.

Nalivkin, D.S., 1966, Bedrock geology map at scale 1:5000 000, GUGK, Moscow.

Sergeev, E.M., 1972, Engineering-geological map Western Siberian plate at scale 1:1 500 000, Moscow University, Moscow.

The map has two main levels of information (figures 1.1 and 1.2)

Level 1 - This level shows landscape zones, subzones, and altitudinal-longitudinal landscape boundaries. For verification of these boundaries, data on plain and highlands and mountainous regions (zone A and B in a figure 1.1) alterations were taken into account. The prevailing type of ground (soils or rocky) and surface morphology, characteristic for different types of plain or mountain regions, were also considered. In addition, vegetation and soils features were taken into account. The boundaries on the map (figure 1.1) are shown as bold lines.

Level 2 - This level shows morphogenic groups and landscape varieties. At this level there is a detailed elaboration of the landscape structures. It is obvious that plains can be either low or raised, and hard rocks can be discovered among sedimentary grounds and soils. On the other hand, between dislocated rocky mountain structures, there can be depressions filled with glacial complex soils, and the coastal parts of valleys may be filled with alluvial and sea sediments.

All these features of landscapes and grounds are reflected on the detailed level of the landscape map. The light grounds can be formed by soils from clay up to sand and gravel; sometimes they can be saline. Rocky grounds can be carbonate or noncarbonate, and can be soluble or insoluble by water. Some grounds can be acidic or nonacidic. An eight-digit index permits coding of all named information on each landscape site. 


\section{Literature}

Gudilin, I.S., Komarov, I.S., 1978, Primenenie aerometodov pri ingenerno-geologicheskih issledovaniyah [The use of air photoimages in engineering geological research], 'Nedra', Moscow, $320 \mathrm{pp}$.

Walker, D.A., 1998; An integrated vegetation mapping approach for the Circumpolar Arctic Vegetation Map; in Markon, C.J., and Walker, D.A., Proceedings of the Third International Circumpolar Arctic Vegetation Mapping Workshop, Anchorage, AK, 3-7 June, 1998: U.S. Geological Survey Open-File Report 99-551. 


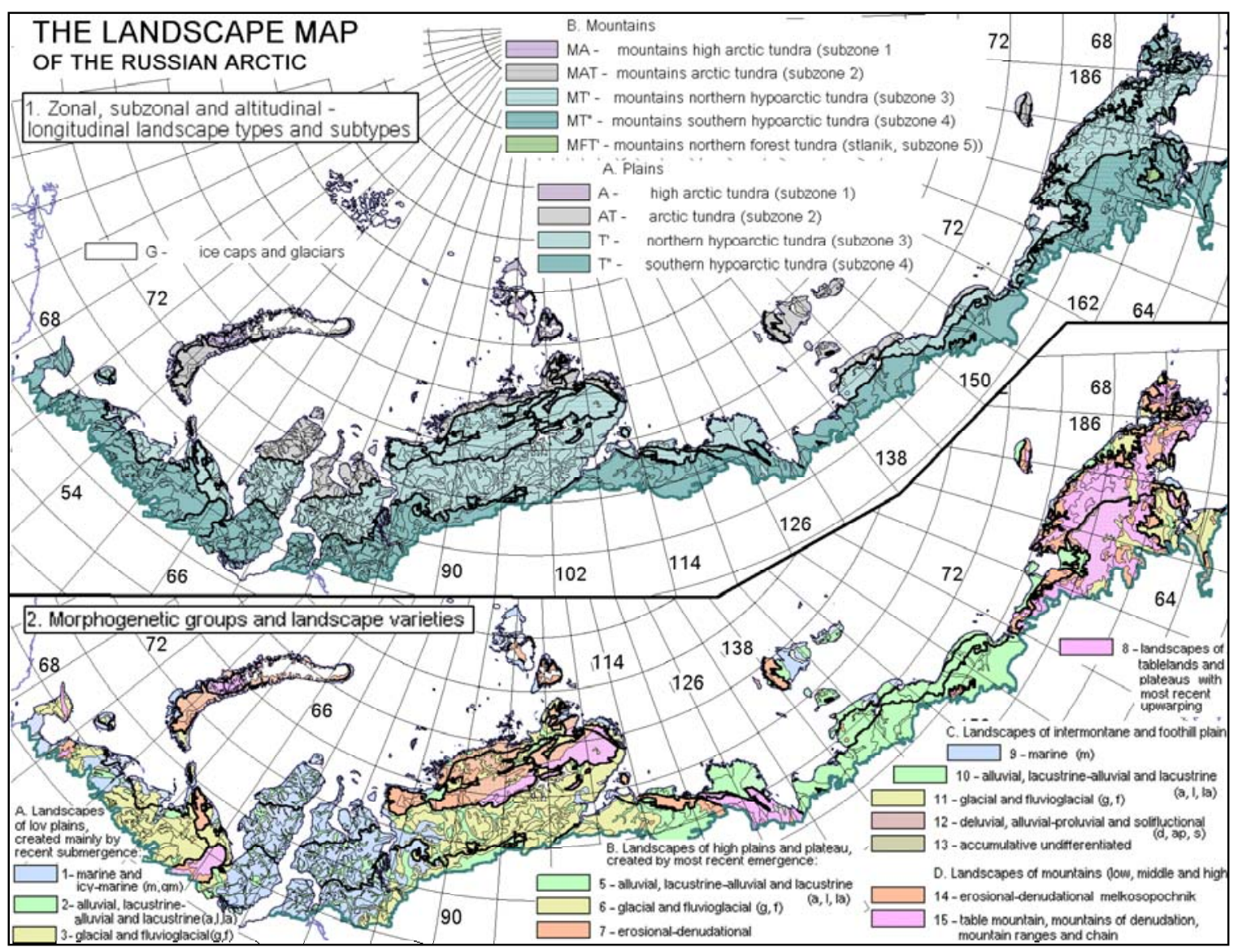

Figure 1. (1) Landscape map of the Russian arctic (1 - Zonal, Subzonal, and altitudinal-longitudinal landscape types; (2) Morphogenetic groups and landscape varieties). 


\title{
VEGETATION MAP OF EUROPEAN RUSSIA
}

\author{
Sergei S. Kholod \\ Komarov Botanical Institute, prof. \\ Popov Str. 2, \\ St.-Petersburg, Russia \\ and \\ Galina V. Ananjeva \\ Earth Cryosphere Institute, \\ Vavilova, 30, \\ Moscow, Russia \\ E-mail: emelnikov@mtu-net.ru
}

The vegetation map of European Russia is based on the polygons of the landscape map. The southern border of the tundra zone is from the "Vegetation map of the European part of USSR, " at a scale of 1:2,500,000 and produced in 1979. This border has a distinct winding character as a result of forest islands and other inclusions from the tundra zone. The second basis of the vegetation map is the map of geobotanical and floristical subdivisions of the arctic zone. The look-up table database was used when the map legend was compiled.

The broadest division of the legend is bioclimatic subzones. The arctic region of European Russia is divided into five subzones, which correspond to divisions of this territory on the "Map of natural vegetation of Europe" (1:2,500,000-scale; Bon-Bad-Godesberg, 2000). These are (1) high arctic tundra, (2) northern arctic tundra, (3) southern arctic tundra, (4) northern hypoarctic tundra, and (5) southern hypoarctic tundra. Each subzone is then divided into large units of relief (macrorelief): low plain, high plain and plateau, low mountains, intermontane and foothill plain, and mountains. The essential problem was to find agreement between units of macrorelief and vegetation, because the borders of macrorelief and vegetation do not always coincide as a result of using existing vegetation maps. The contours of vegetation in these maps were not created on the basis of landscape or geomorphological maps. In some cases, the macrorelief polygons were smaller than the polygons of the vegetation map, and in these cases we had to divide polygons. In other cases, the polygons of macrorelief were larger than the vegetation ones that required us to combine several vegetation units into one. There were some difficulties in these cases as to how to substantiate the individuality of vegetation polygons that were the same as adjacent polygons on the map; in other cases, there were difficulties regarding how to substantiate the integrity of a complex unit that consisted of simple units.

The next hierarchical level was sources of surficial deposits: marine, moraine and fluvioglacial, erosion, and lake-alluvial. A further subdivision was made for substrate texture (sandy, coarse rubble, clayloamy, stone deposits) and geochemical character (acidic, nonacidic). Then the vegetation-mapping unit itself follows, shown by the colour and the number of the polygon label. Some numbers in the legend have been grouped according to macrorelief type. For example, numbers 20, 21, and 22 are vegetation of low mountains and foothill plains to the north of the Polar Urals, and are shown as a gray colour. The choice of mapping unit represents one or another combination of units from the look-up table. According to this table, the name of the life form that predominates in one or another layer and a list of main dominants of vegetation are mentioned.

\section{Tundra Types}

The high arctic tundra occurs in Franz Josef Land and in Novaja Zemlja (vegetation types 1 and 2), and these two types include both nonacidic and acidic vegetation. The occurrence of both nonacidic and acidic occurs in this subzone is shown in the legend. In many other cases it is difficult to find exact correspondence between landscape polygons and polygons with one geochemical type of vegetation.

Northern arctic tundras are found in Novaja Zemlja and Vaigach Island (a narrow strip along the southern coast). Nonacidic and acidic vegetation is found here, as well as in high arctic tundras; in this case, the nonacidic vegetation tends to occur in rocky habitats. There are high plains in the middle of Vaigach Island, in the plateau on the south of Novaja Zemlja, and in the ice-free strip on the north of Novaja Zemlja. Some polygons that correspond to this vegetation (vegetation types 7 and 8 ) extend toward 
the northern edge of Novaja Zemlja and border with high arctic tundras. On the neutral and lightly carbonate substrates, nonacidic vegetation (with Dryas octopetala ssp. subincisa, Saxifraga oppositifolia) is common (vegetation type 5).

Southern arctic tundras occupy the southern edge of Novaja Zemlja and coastal parts of Vaigach Island. The main criterion for distinguishing subzone 3 is the greater cover of vegetation and the disappearance of cushion plants. Sedges and grasses, as well as mosses, usually characterize the vegetation of subzone 3 . Vegetation of wet and moist habitats is common for the low plain (there are flat bogs and wet tundras) (vegetation type 9); moreover, communities with Salix polaris are common here (vegetation type 10). According to Alexandrova (1956), this vegetation characterizes the zonal type in southern arctic tundras.

The northern hypoarctic tundras are found along a strip that borders the coastline, with some in Kolguev Island. The width of this strip increases to the east of the subzone. Most of these units are situated on low marine or fluvioglacial plains. It is the reason why flat bogs predominate here (vegetation types 11 and 12). At some distance from sea, coastal tundras with low Betula nana predominate (vegetation types 16, 17, and 18). In the eastern part of the subzone, in the foothill plains, the role of dwarf shrubs increases (vegetation types 20, 21, and 22).

Southern hypoarctic tundras extend in a broad strip from the Kanin Peninsula to the foot of the Polar Urals. These tundras show the maximum diversity (20 types out of 44). Practically all vegetation of this subzone belongs to the acidic variant that formed on moraine and fluvioglacial plains. In the low plains, which are found in the western part of the subzone, low birch (Betula nana) tundras predominate; also, large systems of raised bogs are common (vegetation types $25,26,31$, and 34). A separate legend number (28) represents the vegetation of salt coastal strips (salt marshes) that spread on the coast of Checshkaja Bay. To the east of Petschora, tall shrubs are widespread (vegetation types 37, 38, and 39). Two numbers of the legend show the vertical zonation in the Polar Urals (vegetation types 43 and 44). A few communities, from upper to lower, characterize the vertical series. 


\section{Literature cited}

Alexandrova, V.D., 1956, The vegetation of southern Novaja Zemlja Island: Vegetation of far north and its assimilation (In Russian), 2, p. 187-306.

Bonn-Bad-Godesberg, 2000, Map of the natural vegetation of Europe (1:2,500,000-scale).

Vegetation map of the European part of the USSR. Scale 1: 2500 000, Moscow, 1979, on 6 sheets. 


\title{
VEGETATION MAP OF WEST SIBERIA, TAIMYR, AND YAKUTIA
}

\author{
Natalia G. Moskalenko \\ Earth Cryosphere Institute, SB RAS, \\ 30/8 Vavilov Str., \\ Moscow, 117982, Russia \\ E-mail: emelnikov@mtu-net.ru; morstepa@mtu-net.ru
}

The Vegetation Map of West Siberia, Taimyr, and Yakutia was compiled on the basis of the following cartographic sources: (1) Vegetation Map of the USSR, 1:4,000,000-scale (Belov, 1990); (2) Vegetation Map of the Yamal-Nenetzky National District, 1:1,000,000-scale (Avramchik, 1961); (3) Vegetation Map of the West Siberian Plain, 1:1,500,000-scale (Sochava, 1976); (4) the Map of Vegetation and Fodder Stocks of the Taimyr National District, 1:500,000-scale (Shchelkunova, 1974-1976); and (5) Vegetation Map of Yakutia, 1:5,000,000-scale, included in the Agricultural Atlas of Yakutia (Andreev, 1987). Results of field studies performed by Matveyeva (1998) and Moskalenko (1999) were also taken into account.

An Integrated Map of Landscape Units of the Russian Arctic was used as a cartographic basis for the vegetation map, in agreement with the method proposed by D.A. Walker (1998) for the Circumpolar Arctic Vegetation Map. The legend of the vegetation map is based on specially compiled look-up tables, containing information on dominant plant communities found under different landscape conditions. N.V. Matveyeva prepared look-up tables for the Taimyr Peninsula and Yakutia.

The legend is organized on the zonal principle: characterization of plant communities starts from the High Arctic Tundra zone. First, the vegetation of plains is characterized and then the vegetation of mountains. The description of plant communities predominating within those types of plains (marine, glacial, etc.) that are shown on the map of landscape units is given. Sometimes, a single predominant type of tundra vegetation can characterize a certain type of plain; however, more often it is characterized by a particular combination of different types of tundra vegetation. Vegetation descriptions are accompanied by a brief characterization of environmental conditions (moisture conditions, character of the substrate); e.g., prostrate dwarf shrub-sedge-lichen tundra (Salix nummularia, Carex bigelowii ssp. arctisibirica, Alectoria ochroleuca, A. nigricans, Bryocaulon divergens) on dry sandy acidic sites in low marine plains.

The analysis of the Landscape Map of Western Siberia, the base map for the Vegetation Map, shows that low marine plains composed of clayey and sandy deposits and dissected by river valleys and lake depressions predominate in the Arctic and Northern Hypoarctic tundra subzones. In the Southern Hypoarctic tundra subzone, along with predominant low marine plains, glacial plains composed of clayey and sandy substrates with considerable admixture of pebbly material are known in the eastern part of Gydan Peninsula, and glacial and lacustrine-alluvial plains predominate in the west of the territory, in the Ural region.

The relatively simple and homogeneous geological background of this territory imposes certain effects on the character of vegetation. A clear dependence of vegetation on climatic conditions with well-expressed latitudinal zonality is observed (figure 1). For example, sedge-moss tundras of the Arctic subzone with predominant Carex arctisibirica and Aulacomnium turgidum in mesic acidic clayey and sandy sites are replaced in the Northern Hypoarctic subzone by hemiprostrate dwarf shrub-sedge-moss tundras dominated by Betula nana, Carex arctisibirica, and Aulacomnium turgidum. Hemiprostrate dwarf shrub-moss-lichen tundras dominated by Betula nana, Salix pulchra, Ledum decumbens, Aulacomnium turgidum, and Cladina stellaris occupy similar sites in the Southern Hypoarctic subzone. In the Hypoarctic subzones, these tundras usually form combinations with tussock cottongrass-moss tundras (Eriphorum vaginatum, Sphagnum lenense, S. warnstorfii).

Zonal features are well manifested even in the mire vegetation of Western Siberia. Thus, in the Arctic subzone, sedge-moss mires with predominant Carex stans, Eriophorum polystachion, and Warnstorfia sarmentosa are widespread. In the Northern Hypoarctic subzone, they are replaced by hemiprostrate dwarf shrub-sedge-moss polygonal bogs (Ledum decumbens, Betula nana, Carex stans, Sphagnum lenense). In the Southern Hypoarctic subzone, along with relatively homogeneous sedge-moss mires and polygonal bogs, complex combinations of hemiprostrate dwarf shrub-forb-lichen-moss palsa bogs (Ledum 
decumbens, Rubus chamaemorus, Sphagnum balticum, and Cladina stellaris) and sedge-forb-moss mires (Carex aquatilis, Comarum palustre, and Sphagnum lindbergii) are quite common.

Nonacidic soils connected with clayey saline marine deposits occupy large areas in the Northern Hypoarctic tundra (Ukraintseva, 1997). Prostrate dwarf shrub-forb-moss tundras with a predominance of Dryas punctata, Saxifraga nelsoniana, and Dicranum congestum develop on these soils on hill tops; the slopes are occupied by forb-moss willow shrublands dominated by Salix glauca, S. lanata, Petasites frigidus, and Aulacomnium palustre.

Intrazonal vegetation in the Arctic and Northern Hypoarctic subzones is represented by halophytic meadows dominated by Puccinellia phryganodes and Carex subspathacea, occupying very small areas on wet saline clayey and sandy soils.

In contrast to Western Siberia, the Taimyr Peninsula is characterized by a very complicated geological structure. Many kinds of plains (low coastal marine plains, foothill plains covered by marine deposits, lacustrine-alluvial plains, and glacial plains) can be found in this region. Glacial plains composed of clay loamy or, less frequently, sandy deposits with an admixture of pebbly and boulder material predominate. Mountain landscapes of low and medium-high mountains composed of stony bedrocks overlain by a thin layer of weathered material also occupy large areas (the Byrranga Ridge). All natural subzones, from high arctic tundra to southern hypoarctic tundra, are expressed.

The complicated landscape structure of the Taimyr region corresponds to a great diversity of plant communities. Vegetation of the High Arctic subzone in the Severnaya Zemlya islands, which have a significant proportion of glaciers, occupies low-mountain sites with very poor moss-lichen tundra dominated by Neuropogon sulphureus and Racomitrium lanuginosum, and foothill plains with richer grassmoss tundra with Deschampsia borealis, Alopecurus alpinus, and Aulacomnium turgidum.

The Arctic vegetation subzone occupies a narrow strip along the continental coast. Foothill plains in this subzone are covered by grass-prostrate dwarf shrub-moss tundra with Alopecurus alpinus, Salix polaris, Tomentypnum nitens, and Hylocomium splendens. In the mountains, they are replaced by sparse communities of Ochrolechia frigida, Ditrichum flexicaule, and Papaver polare, with fragments of prostrate dwarf shrub-moss tundra (Dryas punctata, Racomitrium lanuginosum).

The Northern Hypoarctic subzone occupies the largest area. The proportions of mountainous tundra and tundra of glacial plains are approximately equal in this subzone. Glacial plains are occupied by sedgeprostrate dwarf shrub-moss tundra dominated by Dryas punctata, Carex arctisibirica, Tomentypnum nitens, and Hylocomium splendens. Low mountains are covered by forb-prostrate dwarf shrub-hemiprostrate dwarf shrub-moss tundra (Dryas punctata, Cassiope tetragona, Novosieversia glacialis, and Racomitrium lanuginosum). In medium-high mountains, they are replaced by the groupings of Ochrolechia frigida, Ditrichum flexicaule, Papaver polare, Minuartia arctica, and Draba glacialis.

The Southern Hypoarctic subzone is rather homogeneous with respect to its landscape structure. Low glacial and lacustrine-alluvial plains with low shrub-hemiprostrate dwarf shrub-prostrate dwarf shrubsedge-moss tundra with Alnus fruticosa, Salix reptans, S. pulchra, Ledum decumbens, Vaccinium microphyllum, Dryas punctata, Carex arctisibirica, Tomentypnum nitens, Hylocomium splendens, Aulacomnium turgidum, and Ptilidium ciliare predominate in this subzone.

The landscapes of Yakutia (within the tundra zone) occupy an intermediate place between the extremely complicated landscapes of Taymyr and the rather simple and homogeneous landscapes of Western Siberia. In the western part of the Yakutian tundra, low lacustrine-alluvial plains with some inclusions of glacial and marine plains composed of sandy and clayey deposits predominate. High eroding plains and plateaus occupy minor areas. In the east of Yakutia, foothill lacustrine-alluvial plains composed of clayey deposits are very common; marine plains occupy smaller areas; mountainous landscapes create small spots in the landscape structure.

All four natural vegetation subzones are expressed, but the High Arctic subzone distinguished in the De Long Islands occupies a very small area. The subzone of Arctic Tundra occupies the Novosibirskiye Islands and coastal areas in the eastern part of Yakutia. Foothill plains are covered by prostrate dwarf shrub-lichen-moss tundra dominated by Salix polaris, Dryas punctata, Aulacomnium turgidum, Hylocomium splendens, and Flavocetraria cucullata alternating with sedge-moss tundras (Carex stans, Eriophorum polystachion, Aulacomnium turgidum) or with polygonal sedge-sphagnum bogs. Lichen tundras (Rhizocarpon geographicum, Haematomma ventosum, Alectoria ochroleuca, Bryocaulon divergens), prostrate dwarf shrub tundras (Dryas punctata, Cassiope tetragona), and grass-prostrate dwarf 
shrub-moss tundras (Alopecurus alpinus, Salix polaris, Ditrichum flexicaule, Distichium capillaceum) are characteristic of low-mountain landscapes in this subzone.

In the Northern Hypoarctic subzone of western Yakutia, low plains are occupied by prostrate dwarf shrub-sedge-moss tundras (Carex stans, Eriophorum polystachion, Salix polaris) in combination with polygonal sedge-sphagnum bogs. Saline soils in some coastal areas are overgrown by grass-sedge halophytic meadows very similar to those in Western Siberia.

The foothill plains of eastern Yakutia are covered by tussock cottongrass-moss tundras dominated by Eriophorum vaginatum and Aulacomnium turgidum, often in combination with polygonal sedge-sphagnum bogs. The vegetation of eroding plateaus is represented by lichen tundras (Alectoria ochroleuca, Bryocaulon divergens) and dwarf shrub tundras dominated by Dryas punctata and Cassiope tetragona.

In the Southern Hypoarctic subzone of western Yakutia, low shrub-lichen-moss tundras (Betula exilis, Salix pulchra, Aulacomnium turgidum, Hylocomium splendens, Flavocetraria cucullata) predominate. In the eastern part, Eriophorum vaginatum is very typical of low shrub tundras. A combination of true tundras with low shrub polygonal bogs is found in this area.

The analysis of this map shows that the vegetation in different parts of the considered territory displays significant essential floristic and physiognomic differences caused by geological and climatic features of these regions. However, mire and halophytic plant communities of different regions have much in common. 


\section{References}

Andreev, V.N., 1987, Vegetation map in the Agricultural Atlas of Yakutia, 1: 5,000,000- scale.

Avramchik, M.N., 1961, Vegetation map of the Yamal-Nenetzky national district, 1: 1,000,000-scale.

Belov, V.A., 1990, Vegetation map of the USSR, 1:4,000,000-scale, GUGK, Moscow.

Matveyeva, N.V., 1998, Zonation in the plant cover of the Arctic: Proceedings of the Komarov Botanical Institute, issue 21, St. Petersburg, Russia, 220 pp.

Moskalenko, N.G., 1999, Anthropogenic dynamics of vegetation dynamics in permafrost plains of Russia, Novosibirsk: Nauka, 280 pp.

Shchelkunova, R.P., 1974-1976, Vegetation map and fodder stocks of the Taymyr national district, 1:500,000-scale: Rosgiprozem.

Sochava, V.B., 1976, Vegetation map of the West Siberian Plain on a scale of 1:1,500,000: GUGK, Moscow.

Ukraintseva, N.G., 1997, The shrub willow tundra of Yamal as an indicator of the salinity degree of surface deposits: Fundamental Research of the Earth Cryosphere in the Arctic and Subarctic, Novosibirsk, Nauka, p. 182-187.

Walker, D.A.; 1998, An integrated vegetation mapping approach for the Circumpolar Arctic Vegetation Map, in Markon, C.J., and Walker, D.A., Proceedings of the Third International Circumpolar Arctic Vegetation Mapping Workshop, Anchorage, AK., 3-7 June, 1998: U.S. Geological Survey Open-File Report 99-551. 


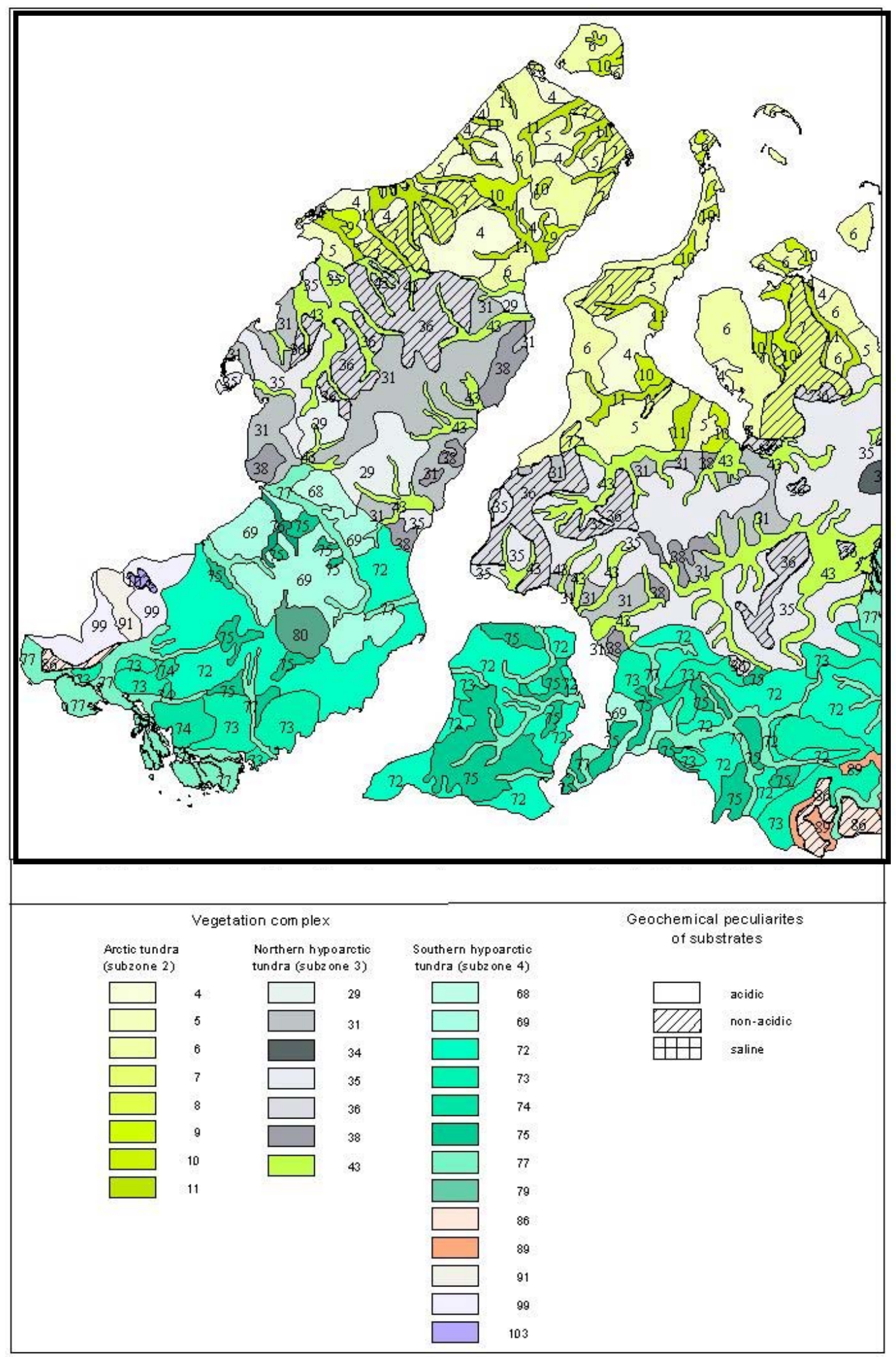

Figure 1. Fragment of provisional vegetation map of West Siberia. 


\section{LEGEND FOR MAP OF WEST SIBERIA}

\section{Arctic Tundra (subzone 2)}

4. Prostrate dwarf shrub-sedge-lichen tundras (Salix nummularia, Carex bigelowii ssp. arctisibirica, Alectoria ochroleuca, A. nigricans, Bryocaulon divergens) on dry sandy acidic sites [12WS]

5. Grass-lichen-moss tundras (Hierochloe alpina, Flavocetraria cucullata, Thamnolia vermicularis, Cladina arbuscula ssp. mitis) on dry sandy and clay acidic sites [11WS]

6. Sedge-moss (Carex bigelowii ssp. arctisibirica, Aulacomnium turgidum, Dicranum angustum) tundras on mesic clay and sandy acidic sites [17WS]

7. Prostrate dwarf shrub-sedge-forb-moss (Dryas octopetala ssp. subincisa, D. punctata, Salix polaris, Carex bigelowii ssp. arctisibirica, Papaver lapponica, Dicranum elongatum, Ptilidium ciliare) tundras on mesic clay nonacidic sites [30WS-31WS]

8. Grass-sedge meadows (Puccinellia phryganodes, Carex subspathacea) on wet saline clay and sandy sites [33WS, 9Y-10 Y]

9. Sedge-moss mires (Carex aquatilis ssp. stans, Eriophorum polystachion, Warnstorfia sarmentosa, W. exannulata, Sphagnum squarrosum) on wet sandy and peaty acidic sites [21WS-22EWS]

10. Sedge-moss mires (Carex aquatilis ssp. stans, Eriophorum polystachion, E. russeolum, Warnstorfia sarmentosa, W. exannulata, Sphagnum squarrosum, S. girgensohnii) on wet sandy, clay, and peaty acidic sites [18EWS-21WS-22EWS]

11. Sedge-moss polygonal bogs (Carex aquatilis ssp. stans, Eriophorum polystachion, Warnstorfia sarmentosa) in combination with willow shrublands (Salix reptans, S. glauca, Pedicularis sudetica) and sedge-moss tundras (Carex bigelowii ssp. arctisibirica, Dicranum angustum) on sandy and clay acidic sites in valleys [26WS+27WS+28WS]

\section{Northern Hypoarctic Tundra (subzone 3)}

29. Prostrate dwarf shrub-lichen tundras (Salix nummularia, Dryas octopetala ssp. subincisa, Flavocetraria cucullata) on dry sandy acidic sites [38WS]

31. Hemiprostrate dwarf shrub-erect dwarf shrub-lichen-moss tundras (Ledum decumbens, Vaccinium vitisidaea ssp. minus, Flavocetraria cucullata, Racomitrium lanuginosum) on dry sandy acidic sites [39 WS]

34. Grass-sedge meadows (Puccinellia phryganodes, Carex subspathacea) on wet saline clay and sandy sites [72WS, 16Y-17Y-31Y]

35. Hemiprostrate dwarf shrub-sedge-moss tundras (Betula nana, Carex arctisibirica, Aulacomnium turgidum) on mesic clay and sandy acidic sites in combination with tussock sedge-moss tundras (Eriphorum vaginatum, Sphagnum lenense, S. warnstorfii) on moist acidic sites [45WS+48WS49EWS]

36. Prostrate dwarf shrub-forb-moss tundras (Dryas punctata, Saxifraga nelsoniana, Dicranum congestum) in combination with shrublands (Salix glauca, S. lanata, Petasites frigidus, Aulacomnium palustre) on mesic nonacidic sites [68WS+70WS-71WS]

38. Sedge-moss mires (Carex aquatilis, C. rotundata, Eriophorum russeolum, Warnstorfia fluitans, W. exannulata, Pseudobryum cinclidioides) and hemiprostrate dwarf shrub-sedge-moss polygonal bogs (Ledum decumbens, Betula nana, Carex aquatilis ssp. stans, Sphagnum lenense) on wet peaty, clay, and sandy acidic sites [51EWS, 54WS]

43. Sedge-moss mires (Carex aquatilis ssp. stans) in combination with willow shrublands (Salix lanata, Calamagrostis neglecta, Aulacomnium turgidum) and hemiprostrate dwarf shrub-moss tundras (Betula nana, Salix glauca, Aulacomnium turgidum) on sandy and clay acidic sites in valleys $[60 \mathrm{WS}+61 \mathrm{WS}+62 \mathrm{WS}]$ 


\section{Southern Hypoarctic Tundra (subzone 4)}

68. Hemiprostrate dwarf shrub-erect dwarf shrub-prostrate dwarf shrub-lichen (Ledum decumbens, Vaccinium vitis-idaea ssp., Empetrum subholarcticum, Arctous alpina, Cladina arbuscula, C. stellaris) on dry sandy acidic sites [79WS]

69. Hemiprostrate dwarf shrub-erect dwarf shrub-prostrate dwarf shrub-lichen tundras (Ledum decumbens, Vaccinium vitis-idaea sp., Empetrum subholarcticum, Arctous alpina, Cladina arbuscula, C. stellaris) on dry sandy sites in combination with prostrate dwarf shrub-sedge-forb-lichen-moss tundras (Dryas octopetala ssp. subincisa, Carex bigelowii ssp. arctisibirica, Minuartia macrocarpa, Hedysarum hedysaroides ssp. arcticum, Valeriana capitata, Cladina rangiferina, Racomitrium lanuginosum) on dry clay acidic sites [79WS+77WS]

72. Hemiprostrate dwarf shrub-moss-lichen tundras (Betula nana, Salix pulchra, Ledum decumbens, Aulacomnium turgidum, Hylocomium splendens, Ptilidium ciliare, Dicranum angustum, Cladina stellaris, C. rangiferina, Flavocetraria cucullata) on mesic clay and sandy acidic sites in combination with tussock sedge-moss tundras (Eriophorum vaginatum, Dicranum elongatum, Sphagnum balticum) on clay moist acidic sites [85WS+84WS]

73. Hemiprostrate dwarf shrub-prostrate dwarf shrub-moss-lichen tundras (Betula nana, Salix pulchra, Ledum decumbens, Dryas punctata, Aulacomnium turgidum, Hylocomium splendens, Ptilidium ciliare, Dicranum angustum, Cladina stellaris, C. rangiferina, Flavocetraria cucullata) on mesic clay acidic sites in combination with low shrub-forb tundras (Salix lanata, S. glauca, Betula nana, B. exilis, Polemonium acutiflorum, Ranunculus borealis, Veratrum lobelianum) on mesic clay gentle slopes and low shrub-hemiprostrate dwarf shrub-forb-moss tundras (Salix lanata, S. glauca, Betula nana, B. exilis, Vaccinium uliginosum ssp. microphyllum, Parnassia palustris, Pedicularis sudetica, Aulacomnium palustre, Polytrichum commune, Tomentypnum nitens) on moist clay acidic gentle slopes [85WS+86WS-87WS]

74. Hemiprostrate dwarf shrub-forb-lichen-moss palsa bogs (Ledum decumbens, Rubus chamaemorus, Cladina stellaris, Sphagnum balticum, Dicranum congestum) in combination with sedge-forb-prostrate dwarf shrub-moss mires (Carex aquatilis, C. rotundata, Eriophorum polystachion, Comarum palustre, Menyanthes trifoliata, Oxyccocus microcarpus, Sphagnum lindbergii, S. squarrosum) on wet peaty and clay acidic sites [95WS+91WS]

75. Hemiprostrate dwarf shrub- prostrate dwarf shrub-forb-moss polygonal bogs (Ledum decumbens, Andromeda polifolia ssp. pumila, Oxyccocus microcarpus, Rubus chamaemorus, Sphagnum fuscum, $S$. balticum, S. riparium, Dicranum congestum) in combination with sedge-forb-prostrate dwarf shrubmoss mires (Carex aquatilis, C. rotundata, Eriophorum polystachion, Comarum palustre, Menyanthes trifoliata, Oxyccocus microcarpus, Sphagnum lindbergii, S. squarrosum) on wet peaty, clay, and sandy acidic sites [94EWS+91WS]

77. Sedge-moss mires (Carex aquatilis, C. chordorrhiza, Eriophorum polystachion, Calliergon stramineum, Aulacomnium palustre, Sphagnum squarrosum) in combination with grass-forb-moss shrublands (Salix lanata, S. glauca, Alnus fruticosa, Calamagrostis langsdorffii, Pedicularis sudetica, Petasites frigidus, Aulacomnium turgidum, Hylocomium splendens, Pleurozium schreberi) and hemiprostrate dwarf shrub-lichen-moss tundras (Betula nana, Vaccinium uliginosum ssp. mycrophyllum, Cetraria islandica, Cladina rangiferina, Dicranum angustum, Polytrichum hyperboreum) on sandy and clay acidic sites in valleys [101WS-102WS+103WS-104WS+108WS]

79. Sedge-forb-hemiprostrate dwarf shrub-prostrate dwarf shrub-moss mires (Carex aquatilis, C. rotundata, Comarum palustre, Chamaedaphne calyculata, Salix myrtilloides, Sphagnum lindbergii, S. squarrosum) on wet peaty, clay and sandy acidic sites in combination with low shrub-hemiprostrate dwarf shrub-forb-moss tundras (Salix lanata, S. glauca, Betula nana, Vaccinium uliginosum ssp. mycrophyllum, Pedicularis sudetica, Aulacomnium palustre, Tomentypnum nitens) on clay mesic acidic sites [91WS+87WS]

86. Low shrub prostrate dwarf shrub-forb-lichen-moss tundras (Dryas octopetala ssp. subincisa, D. punctata, Pedicularis sudetica, Diapensia lapponica, Alectoria ochroleuca, Flavocetraria cucullata, 
Cladina arbuscula, Racomitrium lanuginosum) on dry gravelly, sandy, and clay nonacidic sites [114WS]

89. Sedge-moss tundras (Carex ledobouriana, C. gracilis, Dicranum elongatum, Hylocomium splendens) on mesic clay nonacidic sites [115WS]

91. Low shrub-hemiprostrate dwarf shrub-moss tundras (Betula nana, Salix glauca, Vaccinium uliginosum, Hylocomium splendens, Pleurozium schreberi Aulacomnium palustre) on mesic sandy and clay acidic sites in combination with hemiprostrate dwarf shrub-forb-lichen-moss palsa bogs (Ledum palustre, Rubus chamaemorus, Cladina stellaris, C. rangiferina, Sphagnum fuscum) on wet acidic sites [87 $\mathrm{WS}+95 \mathrm{WS}]$

99. Low shrub-hemiprostrate dwarf shrub-lichen tundras (Betula nana, Ledum decumbens, Flavocetraria cucullata, Cetraria islandica, Cladina arbuscula, C. rangiferina) on dry sandy acidic sites in combination with low shrub-hemiprostrate dwarf shrub-moss tundras (Betula nana, Salix glauca, Vaccinium uliginosum, Hylocomium splendens, Pleurozium schreberi, Aulacomnium palustre) on mesic clay acidic sites [79WS+87WS]

103. Sedge-prostrate dwarf shrub-moss tundras (Carex ledobouriana, Dryas octopetala ssp. subincisa, Racomitrium lanuginosum, Aulacomnium turgidum) on dry nonacidic rocky sites [124 WS]

[ ] indicates code used in look-up tables 


\title{
SOME COMMENTS ON THE MAPPING OF CIRCUMPOLAR ARCTIC VEGETATION
}

\author{
Boris A. Yurtsev \\ Laboratory of Far North Vegetation, \\ Komarov Botanical Institute, \\ St. Petersburg, 197376, Russia \\ E-mail: yurtsev@IK6026.spb.edu
}

Ecologic-floristic or Braun-Blanquet tradition (Br.-Bl) and ecological-structural (or dominant, RussianEnglish-American tradition) approaches to the classification of vegetation (including that of the Arctic) are, in fact, complementary and irreplaceable. The first focuses on the species composition of a community as a flora of habitat, whereas the second emphasizes the vertical and horizontal structure of the community as a coenobiotic competitive system of biomorphs, or ecobiomorphs, or coenobiomorphs, or "functional types, " as well as the quantitative relation between them (dominants, subdominant). The advantage of the first is a well-established procedure of processing relévés and, as a consequence, a more stable nomenclature of vegetation units. However, only an insignificant part of the full diversity of the Arctic vegetation has been studied with the Br.-Bl. method. Of course, it is easier to list the Br.-Bl. classes within the Arctic; however, the Br.-Bl. nomenclature based on Southern and Middle Europe's vegetation data involves many words alien to Arctic plant names and is unknown and weakly understood by the wide circle of users outside syntaxonomy. Whereas the ecological-structural (-dominant) approach to the sorting of variety of plant communities could be more easily applied to every area within and outside the Arctic, it is helpful for deciphering images on aerial photographs, and for modeling ecosystems. But the terminology for describing the structure of plant communities should be standardized. The Russian tradition also suggests listing (in brackets) the dominant, other abundant, and (where possible) characteristic and differential species representing each biomorph, functional type, etc., which facilitates the recognition of geographic and/or ecological vicariant plant communities. Br.-Bl. names should be given in brackets where available. Such an approach was accepted in the latest map of the vegetation of Europe even for the classical Br.-Bl. regions!

Compiling look-up tables for each sector of each subzone is extremely important, since it shows the structural, ecological, and floristic diversity of vegetation of each phytochorion, ecological, and geographic explicitness, etc. But the matrix of habitats (as elements of a toposequence) accepted in the CAVM project is incomplete. The mesic habitat (intermediate, middle, median with respect to soil moisture and other factors), filling the gap between "dry" and "moist, " is lacking. Identifying "mesic habitats" with "placors" and "zonal vegetation" in many parts of the Arctic (especially the amphi-Beringian sector: subzones E-D) is not correct, because it is in semiarid forest-steppe and steppe areas of Southern Russia, the "homeland" of the concept and term "placor." Here, on loess-like or clayish or silty soils, evaporation through capillaries results in the desiccation of soils and the dominance of xerophyte (steppe) grassland. Whereas in the areas with a thin active layer underlain by thick low-temperature permafrost, loess and silt are (and were in Holocene and some interglacial) cold moist substrates with extreme environments (as a witnessminimal vascular plant diversity in the dwarf shrub- Eriophorum vaginatum-Sphagnum tussock tundra, almost identical in all hypoarctic tundra subzones and rather similar also in the northern taiga woodlands and large stlanik (Pinus pumila) subzones). Placor vegetation (where it does not coincide with mesic vegetation) usually is autonomous and modal and thus reflects the zonal situation. Mesic vegetation should also be considered, though in the kingdom of permafrost it is very often restricted to slopes and thus depends on the aspect of the slope and on the run-off of soil solution from the upland. But, in general, each habitat should be used for the comparison of vegetation of different subzones.

Division of all the habitats, substrates, and vegetation polygons into acidic and nonacidic is insufficient, because "nonacidic" covers essentially different situations: (1) carbonate rocks - alkaline (basic) throughout a toposequencefrom summits (eluvial geochemical landscapes), through slopes (transitive ones, passing lower into the transitive-accumulative), down to pediments and bottoms of valleys (accumulative and supra-aquatic landscapes); (2) basic-to-medium silicious rocks (more or less acidic on summits and crests and upper steep slopes, but almost alkaline or even carbonate in transitive-accumulative geochemical 
positions; this situation is typical of the Okhotsk-Chukotka volcanic belt; (3) at higher latitudes ( in northernmost subzones northern arctic tundra) the $\mathrm{pH}$ of soils, developed on noncarbonate (Mezozoic) rocks increases from acid up to subneutral ( $\mathrm{pH} \mathrm{ca}$. 6), though a contrasting set of plant species occurs on carbonate Paleozoic rocks (Wrangel Island). A special situation also occurs on extensive exposures of ultra-basic rocks and coastal and noncoastal (interior) halophytic associations (the latter are widespread in xeric continental inner parts of Axel-Heiberg and Ellesmere Islands and North Greenland (Peary Land), as well as some inner parts of Wrangel Island.

It would be useful to also include in the toposequence most xeric situations, steppe and cryo-steppe bluffs among them; e.g. steep south-facing slopes, as well as fens, seepages, and swales with moist to semihygric eutrophic tundra due to intensive run-off.

It is extremely important as well to distinguish at least two grades (degrees) in wind exposure and two in snowbed situations (e.g., snow-free and those with thin but more or less continuous snow cover or shortliving and late-melting snowbeds; the short-living snowbeds sometimes approaching mesic habitats). Occurrence of relic steppe communities in the Arctic (tundra zone) may be marked by out-of-scale signs.

Enclaves with extremely continental situations (including an increased landscape role of cryoxeric herbaceous vegetation) should be distinguished and shown for Axel-Heiberg and Ellesmere Islands, Peary Land in north Greenland, and probably also some parts in Banks I., Victoria I., and Wrangel I.

Carbonate and acidic toposequences of vegetation zonation differ from one another in many respects, due to strengthening the positions of eutrophic arctic-alpine herb species on carbonate substrates in subzones D and E (and even in subarctic woodlands) along with the lack of many oligotrophic low arcticsubarctic (=hypoarctic) plant species, including dwarf shrubs. So, the difference between subzone C and D on carbonate substrates is not so dramatic as on acidic substrates, though it is sufficiently well expressed.

The data are rapidly accumulating showing significant differences of zonal positions (range) of geographic populations of many species in various longitudinal sectors of the Arctic (cf. West Siberian, Taimyr and Chukotka sectors). So, many species with northern distribution cannot serve as markers of a certain zonal boundary at their latitudinal limit of distribution. Especially notable is the penetration of many relatively "southern" species (including steppe ones) in Wrangel Island into subzone B (with mean July temperature $3.6^{\circ}$ and $2.4^{\circ} \mathrm{C}$ ), and even active positions of them there. It is impossible to agree with transferring the coastal plain tundras of Wrangel I. into subzone C, as proposed by Razzhivin (1999) and accepted by Elvebakk (1999) and Elvebakk and others (1999). Diverse arguments for their position in subzone B (in contrast to the humid southern arctic tundras of the opposite mainland coast of Central Chukotka) are given and discussed in my earlier publications (Yurtsev, 1987, 1989, $1994 \mathrm{a}, \mathrm{b}$ ). Two to three times richer local floras occur in Wrangel I. as compared with climatically similar ones in continental enclaves of the Canadian Arctic Archipelago, could be explained in terms of continuous (uninterrupted) florogenesis in Wrangel I. since the late Pliocene. Placor vegetation and soils in Wrangel I. are typical of subzone B. Enclaves of more "southern-looking" vegetation in west-central parts of the island belong, by the sum of characters, to subzone $\mathrm{C}$ continental version (and not D!), despite the local presence in protected sites of low shrub willows (Salix richardsonii and S. glauca). But they differ drastically from the northhypoarctic tundras of the mainland of Chukotka, both carbonate and acidic ones.

Unfortunately, the network of polar weather stations was created mostly on sea coasts and lacks inland locations, including various enclaves with more continental climate. The gaps existing in the network will become especially evident after we complete our circumpolar vegetation map. I hope it will stimulate the establishment of a derived bioclimatic project: filling the gaps by creating the automatic weather station with distant recording climatic parameters. Among priority candidatures would be subzone $\mathrm{C}$ enclaves in Wrangel Island and E enclaves in the eastern Chukchi Peninsula. 


\section{References}

Elvebakk, A. 1999, Bioclimatic delimitation and subdivision of the Arctic, in Nordal I. and Razzhivin V., eds., The species concept in the High North: Oslo, p. 81-112.

Elvebakk, A., Elven, R., and Razzhivin, V., 1999, Delimitation, zonal and sectoral subdivision of the Arctic for the Panarctic Flora Project, in Nordal I. and Razzhivin V., eds., The species concept in the High North, 81-112: Oslo, p. 375-386.

Razzhivin, V., 1999, Zonation of vegetation in the Russian Arctic , in Nordal I. and Razzhivin V., eds., The species concept in the High North, 81-112: 0slo, p113-130.

Yurtsev B.A., 1987, The role of historical factor in utilization by plants of extremal environments of the arctic tundra subzone: Botan. Zhurnal., v. 72, no. 11, p. 1436- 1447, (In Russian)*

Yurtsev B.A., 1989, Placor arctic tundras of Wrangel Island (vicinities of Somnitelnaya Harbour): Botan. Zhurnal., v. 74, no. 3, p. 298-313, (In Russian).

Yurtsev B.A., 1994a, Extended summary and conclusions: Arctic tundras of Wrangel Island, St. Petersburg, p. $256-272$.

Yurtsev B.A., 1994b, Floristic division of the Arctic. Journal of Vegetation Science, v. 5, p. 765-776.

*Yurtsev, B.A., 1987, Yurtsev, B.A., 1989 and Yurtsev, B.A., 1994b are provided with summaries in English 


\title{
HIGHER SYNTAXA FROM THE RUSSIAN ARCTIC
}

\author{
Fred J.A. Daniels, \\ Institute of Plant Ecology, \\ Münster 48143, Germany \\ E-mail: daniels@uni-muenster.de
}

The Braun-Blanquet approach is being used more and more by Russian geobotanists for analyzing and classifying the vegetation of Russia (Korotkov and others 1991; Walker and others, 1995; Solomesch, 1997; Mirkin and Naumova, 1998). Since this approach has a long tradition in Northern Europe (Dierssen, 1996) and is meanwhile also being successfully applied in North America (including Greenland; Walker and others, 1995), it should be possible to use Braun-Blanquet syntaxa in the legend construction of circumpolar arctic vegetation maps (CAVM; Daniels, 1997).

A list of higher syntaxa (classes) is presented below, described from the Russian Arctic. The list is derived from two major recent publications: Solomesch (1997) and Mirkin and Naumova (1998). Most syntaxa have a circumpolar distribution. Thus this might encourage Russian colleagues to use the (higher) Braun-Blanquet syntaxa in the description and mapping of the rather convergent circumpolar arctic vegetation. Then we would be using uniform methods, with uniform and unambiguous scientific names for the vegetation types.

\section{Provisional list of syntaxa (classes) described from the Russian Arctic}

The following list of syntaxa was derived from Solomesch (1997) and Mirkin and Naumova (1998), with nomenclature in part adjusted, and vegetation of anthropogenic disturbed sites excluded.

(1) Zosteretea marinae Pignatti 1953 - subeulittoral sea grass vegetation

(2) Juncetea maritimi Br.-B1. 1931 - coastal salt marsh vegetation

(3) Honckenyo-Elymetea arenariae R.Tx. 1966 - dry coastal beach and sand dune vegetation

(4) Potamogetonetea pectinati R.Tx. and Preising 1942 - meso-eutrafent hydrophytic and helophytic vegetation

(5) Montio-Cardaminetea Br.-Bl. and R. Tx. ex Klika et Hadac 1944 - vegetation of oxygen-rich cold springs

(6) Littorelletea uniflorae Br.-Bl. and R. Tx. ex Westhoff et al. 1946 - tropohydrophytic vegetation of oligo-mesotrophic lakes and ponds

(7) Utricularietea intermedio-minoris d. Hartog and Segal 1964 em. Pietsch 1965 - hydrophytic vegetation of oligo-dystrophic small shallow waters and ponds

(8) Isoeto-Nanojuncetea Br.-B1. and R. Tx. ex Westhoff et al. 1946 - small rush vegetation on temporarily moist soil

(9) Equisetetea arvensis Mirkin and Naumova in Kononov et al. 1989 - on banks of East Siberian rivers

(10) Phragmitetea R.Tx. and Preising 1942 - meso-eutrafent helophytic vegetation

(11) Scheuchzerio-Caricetea nigrae (Nordh. 1936) R. Tx. 1937 - sedge grass and dwarf shrub fen vegetation, O. Caricetalia davallianae Br.-B1. 1949, O. Caricetalia fuscae Koch 1926 em. Br.-B1. 1949, O. Scheuchzerietalia palustris Nordhagen 1937, O. Deschampsietalia glaucae Pestryakov and Gogoleva 1991, O. Arctophiletalia fulvae Pestryakov and Gogoleva 1989, O. Caricetalia meyeranae Akhtiamov 1987

(12) Oxycocco-Sphagnetea Br.-Bl. and R. Tx. 1943 - ombrotrophic bog and tussock tundra vegetation

(13) Asplenietea trichomanis Br.-Bl. in Meier and Br.-Bl. 1943 - rock vegetation

(14) Thlaspietea rotundifolii Br.-B1. 1948 - scree and debris vegetation, including that of the "arctic herb zone"

(15) Caricetea curvulae Br.-Bl. in Br.-Bl. and Jenny 1926 - acidic dry sedge and herb vegetation 
(16) Loiseleurio-Vaccinietea Eggler 1952 - acidic dwarf shrub heath vegetation

(17) Mulgedio-Aconitetea Hadac and Klika in Klika and Hadac 1944 - tall herb and shrub vegetation of meadows, block screes and drainage areas

(18) Salicetea herbaceae Br.-Bl. 1947 - snow bed vegetation

(19) Carici-Kobresietea bellardii Ohba 1974 - nonacidic graminoid and dwarf shrub vegetation

\section{Remarks}

The syntaxa in italics are probably confined to Russia. A good syntaxon is still lacking for the arctic steppe vegetation, which is optimally distributed in the amphi-Beringian region. We provisionally named this class Calamagrostietea purpurascentis (Daniels and others, 2000). The same applies for arctic saline steppe vegetation.

Finally, in my opinion the "arctic polar desert vegetation" should be grouped in the future into at least its own higher syntaxon (class, order) (maybe "Saxifrago-Papaveretalia dahlianae", within the Thlaspietea class), or even a class of its own ("Drabo-Papaveretea"). 


\section{References}

Daniels, F.J.A., 1997, Braun-Blanquet syntaxa and their importance for the legend of a circumpolar arctic vegetation map: Occasional Paper No. 52, INSTAAR, Boulder, p. 15-17.

Daniels, F.J.A., Bültmann, H., Lünterbusch, Ch., and Wilhelm, M., 2000, Vegetation zones andbiodiversity of the NorthAmerican Arctic: Ber. d. Reinh-Tüxen-Ges., v. 12, p. 131-151.

Dierssen, K., 1996, Vegetation Nordeuropas, The class Mulgedio-Aconitetea in Siberia: Phytocoenologia, v. 30, no. 2, p.145-192.

Korotkov, K.0., Morozova, O.V., and Belonovskaja, E.A., 1991, The USSR vegetation syntaxa prodromus: Moscow, Vilchek.

Mirkin, B. M., and Naumova, L. G., 1998, Prodromus and list of diagnostical species of the high syntaxa of vegetation on the territory of the former USSR (in Russian with English summary): Ufa, Gilem.

Solomesch, A., 1997, Red Data Book of Plant Communities in the former USSR: Birmingham, Templer Print and Design.

Walker, M.D., Daniels, F.J.A., and van der Maarel, E., 1995, Circumpolar arctic vegetation: Special features in vegetation science 7, Uppsala, Opulus Press. 


\title{
PRINCIPLES OF DESIGN FOR A MAP (LEGEND, COLOR, SHADING)
}

\author{
Irina N. Safronova \\ Department of Vegetation Geography and Cartography \\ Komarov Botanical Institute, \\ Prof. Popov Street, 2, \\ St. Petersburg, 197376, Russia \\ E-mail: irinasaf@is1189.spb.edu
}

Russian vegetation cartographers, including collaborators from the Department of Vegetation Geography and Cartography of the Komarov Botanical Institute of the Russian Academy of Sciences (St. Petersburg), have much experience preparing small-scale vegetation maps for publication.

The most important stage in compiling a map is the construction of its legend. It is by means of a legend that the concept of a map is revealed. Since the end of the 1970s, map legends have been presented in two forms: as text and as a table (Vegetation map of the European part of the USSR, 1979; Vegetation map of the USSR, 1990; Map of reconstructed vegetation of the Central and Eastern Europe, 1996; etc.). In the text, the map legend is a multistage system of subtitles, which reflect the botanical-geographical, and phytocoenotical features of vegetation. The most general mapping units of the legend for plains are phytoceonomeres, taxonomic units of homogeneous vegetation cover (according to the Russian school, they are associations, groups and classes of associations, and formations). Complexes are shown by using phytocoenochorus (territorial units of heterogeneous vegetation cover, including types of complexes, series, combinations, ecological-dynamical series, etc. (Sochava, 1979; Vegetation of Kazakhstan and Middle Asia, 1995). For mountainous areas, on small-scale maps with such units as vegetation belts where it is important to show the effects of altitude, altitudinal zonation can be used.

It is necessary for the legend label to be short and, at the same time, contain a lot of information. As to the order of the label content, it is better to begin with simpler numbers, characterizing homogeneous cover, and then to note any complexes. In the Arctic, there are communities besides tundra vegetation type (for example, meadows, mires, and cryophytic-steppe. These may be separated at the highest rank in the legend structure.

In creating a vegetation map of the Arctic, one must not forget that diverse natural characteristics are revealed through vegetation and only through it! Therefore every subtitle in the legend must disclose certain properties of the vegetation cover itself, rather than environmental characteristics, such as landscape.

The text form of the legend shows the set of dominant and differential species, the structure of vegetation cover (the degree of homogeneity-heterogeneity), and its dynamic status.

In the table form of the legend, mapping divisions are grouped according to their ecology and geographical range, landscape, and other natural components. Ecotypes of plant communities reflect various characteristics of soil substrates (their texture, salt content, $\mathrm{pH}$, etc.), bedrock composition, etc. The following ecotypes may be distinguished: pelitophytic (loamy soils), hemipsammophytic (sandy-loamy soils), psammophytic (sandy soils and sands), hemipetrophytic (organic soils), petrophytic (stoney soils and rocks), halophytic (salty soils, for instance sea beaches), acidophytic (alluvium of acid rocks), and basiphytic (alluvium of calcareous rocks).

Through geographical variants, the regional features are revealed in connection with changes of climatic indices in longitudinal direction within the latitudinal subzone (the degree of continentally) and are characterized by the presence or absence of differential species and by the change of the role of species in vegetation cover.

After the vegetation map is created, at its base, it is possible to carry out a botanical-geographical subdivision of the territory. This subdivision takes into account both phytocoenotical patterns and floristic peculiarities of vegetation. Sometimes there is a temptation to replace a botanical-geographical subdivision by a floristic one. However, it is well known that geobotanical and floristic boundaries don't often coincide; floristic boundaries embrace larger territories. 
Cold gray-dark blue and gray-pale blue shades are traditionally used for the map color of tundra vegetation. These colors reflect the natural environments of the zone under consideration (low temperature, considerable humidity, shortness of vegetation period, etc.). The latitudinal pattern of vegetation cover, its subzonal division, is shown by means of intensification of brightness of color in the southern direction. Undoubtedly, keeping only to cold shades is not a simple task in a detailed portrayal of the complicated vegetation cover of the Arctic. All the same it is better to avoid warm yellow tints for showing the vegetation on acid soils or in wet environments. The possible range of colors may be enlarged by using various shading patterns (they may be of different colors). So, on some published maps the following patterns were used: oblique lines for pelitophytic vegetation; dotted oblique lines for hemipsammophytic vegetation; dots for psammophytic vegetation; dotted lines in different directions for hemipetrophytic vegetation; double dotted lines in different directions for petrophytic vegetation (Vegetation map of Kazakhstan and Middle Asia, 1995).

Typological diversity of vegetation is shown in the legend by numbers. For depicting the regional peculiarities of each subzone, it is possible to use letters. For instance: a) East European arctic tundra, b) Siberian arctic tundra, etc. Mountain vegetation may be singled out by intensification of color of the subzone, or by special shading of other colors than those used for ecotypes, or by using another color than that selected for plain territories.

For showing features, which cannot be depicted at a given scale but are essential for emphasizing particular features of vegetation cover, out-of-scale symbols are used. Usually these are two different colors of letters: black ones duplicating the lower subdivisions of the legend and red ones additional (they are placed at the end of legend). 


\section{References}

Map of reconstructed vegetation of the Central and Eastern Europe. Scale 1: 2,500,000. St. Petersburg, 1996, on 6 sheets. (in Russian and English).

Sochava, V. B., 1979, Vegetation cover on thematic maps: Novosibirsk, $190 \mathrm{p}$.

Vegetation map of Kazakhstan and Middle Asia (in the limits of desert region). Scale $1: 2,500,000$, Moscow, 1995, on 3 sheets.

Vegetation of Kazakhstan and Middle Asia (in the limits of desert region). Explanatory text and legend. Moscow, 1995, 130 p. (in Russian and English).

Vegetation of USSR. Explanatory text and legend. Moscow, 1990, $31 \mathrm{p}$.

Vegetation map of the European part of the USSR. Scale 1: 2,500 000, Moscow, 1979, on 6 sheets. 


\title{
PLAN FOR PUBLICATION OF THE CAVM MAP
}

\author{
Stephen S. Talbot \\ U.S. Fish and Wildlife Service, \\ 1011 East Tudor Road, Anchorage, AK 99503 USA \\ E-mail: Stephen_Talbot@fws.gov
}

\begin{abstract}
One of the goals of the Circumpolar Arctic Vegetation Mapping project was to develop a single vegetation map of the entire circumpolar arctic region (Walker et al., 1995). Toward this end, a number of products were anticipated with both hardcopy and electronic versions of the maps. These were to include a false color infrared image, maximum greenness map, simple land cover map with eight classes, and integrated map coded with landscape and vegetation information. In order to meet the proposed publication date, it is suggested that the CAVM focus first on the production of an initial single-sheet map product ( 48 X 36 in) with information printed on both sides. An initial hardcopy product would fulfill a short-term goal and serve as the first step in producing more detailed maps and a book. The initial product should highlight vegetation complexes and be understandable by both the scientific community and the general public. Given the considerable investment of time, effort, and money spent in developing the Circumpolar Arctic Vegetation Map, the hardcopy map should reflect state-of-the-art technology and be printed on synthetic paper. Synthetic paper offers outstanding surface smoothness to achieve a high level of printability. The CAVM map product should be waterproof, stain resistant, tear resistant, strong, and durable. This will help protect our investment and be of service for years to come. The Conservation of Arctic Flora and Fauna (CAFF) program supported CAVM as a priority action item for completion in 2002; it is recommended that this initial map be published as a CAFF Technical Report. The U.S. Geological Survey, National Research Center, Lafayette, La., provided excellent editing and publication services for a previous CAFF report (Atlas of Rare Endemic Vascular Plants of the Arctic); it is recommended that they assist us in editing, design, layout, and production. An initial estimate for map production indicates that $\$ 20,000$ USD will be required to produce 1,000 maps. Funding is being requested from the U.S. Fish and Wildlife Service, the lead agency for CAFF within the United States.
\end{abstract}




\section{References}

Walker, D.A., Bay, C., Daniels, F.J.A., Einarsson, E., Elvebakk, A., Johanson, B.E., Kapitsa, A.P., Kholod, S.S., Murray, D.F., Talbot, S.S., Yurtsev, B.A., and Zoltai., S.C., 1995, Toward a new arctic vegetation map: a review of existing maps: Journal of Vegetation Science, v. 6, p. 427-436. 


\title{
A DRAFT CIRCUMARCTIC VEGETATION MAP OF THE NORWEGIAN ARCTIC
}

\author{
Arve Elvebakk, \\ Dept. of Biology, N-9037 \\ University of Tromsø, Norway \\ E-mail: arve@ibg.uit.no
}

The Pan-Arctic Flora group has now agreed to include the northernmost parts of the North Atlantic in the definition of the Arctic (Elvebakk et al., 1999). A similar solution will be followed by CAVM. At the time of writing, it is uncertain how much of Iceland will be included, but at least for Fennoscandia the PAF line will be followed. For Fennoscandia, this means that only a narrow strip of the northernmost coasts of Norway and the Kola Peninsula will be included. The strip is marked by the shortest connection lines at the northern limit of the lowland forests, thus eliminating alpine areas south of this line. The major reason for following this line is that there are no criteria to delimit the northernmost 'oroarctic' mountains from areas further to the south in the mountain chains, some of them with a very large longitudinal extension. In addition to the northernmost coastal part of Finnmark, this paper deals with the isolated island of Jan Mayen and with Svalbard. The latter geographic concept also includes the other isolated Norwegian arctic island, Bjørnøya.

These territories are difficult to map on such a coarse scale, because they have very heterogeneous landscapes. Any map polygon then represents a very complicated mosaic of vegetation types, and it is a challenging integrating effort to come up with a rather short description of the mapping units. The Integrated Landscape-Unit Map (ILUM) approach includes several major characteristics, like landforms, bedrock types, and vegetation cover; the latter is a response to hydrology, bedrock types, and climate.

The legend proposed in this draft organizes the units primarily according to their affiliation to bioclimatic zonal units of the Arctic. Climate is thought to be the primary determinate of vegetation at a coarse scale, whereas other factors, such as hydrology and landscape relief, predominate at a more local scale. The approaches of a zone map and a vegetation map are so different that they do not necessarily match. However, this has been achieved in the present draft for Svalbard, primarily owing to the dissected landscape and the presence of numerous small polygons.

There has been a vast literature regarding the bioclimatic zonation of the Arctic, a literature that has been reviewed in most recent studies on the topic. A milestone was reached by Elvebakk et al. (1999), who presented a map with zones/subzones that was widely agreed upon, and that included Greenland in a map system comparable to the remaining parts of the Arctic. At least among the botanists involved in the circumpolar arctic PAF, CAVM, and CFG (CAFF Flora Group) this can be considered a generally accepted basis for further regional improvements. Daniëls et al. (2000) already proposed some boundary revisions in Greenland, and these and future revisions will be updated in the map version available on the PAF Web page http://www.toyen.uio.no/panarctflora/.

There is, however, no consensus on the names applied to the five arctic zonal units, in spite of a thorough and long debate, particularly within CAVM. In a situation without consensus, the arguments will continue in an academic debate, and the different followers will use different proposals. For the CAVM project, the question now should primarily be one of communication: to adopt a well-defined system that will be understood and that can facilitate communication between those advocating different nomenclature systems. Walker (in litt.) proposed that CAVM should continue to use the 'subzone 1-5' name system.

In the present proposal for a legend covering the Norwegian arctic territories, I will use the names proposed by Elvebakk (1999). In the legend, I find it more practical to integrate vegetation physiognomybased names like 'polar desert' 'northern/middle/ southern arctic tundra and arctic shrub-tundra' than numbers or growth form names (see the examples proposed here). In the common CAVM legend, however, the zonal names used here can be replaced by neutral names like 'subzone 1-5'.

The proposed Svalbard CAVM map includes 13 mapping units; 4 units in the arctic polar desert zone, another 4 in the northern arctic tundra zone, and 5 in the middle arctic tundra zone, figures 1-3. In the legends, terms like 'Luzula confusa vegetation' are used. This is to maintain simplicity and to avoid confusing users unfamiliar with syntaxonomy, but these terms are also used because of a lack of knowledge 
about arctic syntaxonomy at a circumpolar scale. However, in the discussion below, syntaxonomic positions of communities are discussed.

\section{Arctic polar desert vegetation}

The arctic polar desert zone as mapped here covers larger areas on Svalbard than on the remaining two warmer zones. Even the glaciated unit A has a small but considerable cover (up to 20 percent) of nunataks, although there are six or seven large ice sheets devoid of nunataks on the islands. Unit B covers large areas on the major island Spitsbergen, with glaciated areas generally below 20 percent. Phytosociological information about nunataks are botanically poorly known, but generally exhibit a polar desert physiognomy, vegetation pattern, and floristic composition above 500-m altitude. In the central areas with sedimentary bedrocks (Winsnes, 1988), most mountains form gravelly plateaus with a very typical polar desert appearance. In the basement rock areas, mountains are steeper and boulders dominate over gravel; cf. the 'Blockmeer' concept used in German and Scandinavian literature. Vascular plant cover is very low, but Racomitrium lanuginosum and other cryptogams can attain a higher cover in stabilized slopes.

Too little is known about the community diversity within the polar deserts, but it is clear that a major difference between vegetation on acidic and circumneutral substrates is maintained also in such a marginal area, in spite of statements that this diversification is depressed so far north with such a strong climate stress; e.g., Virtanen and Eurola (1996). On calcareous and circumneutral soils, Papaveretum dahliani is characteristic. Its syn-systematic position is debated. Its large proportion of high arctic and arctic species speaks against including it in the alliance Arenarion norvegicae, described from mainland Norway, as was done by Möller (2000). In my opinion it is also questionable to include it in the Thlaspietalia rotundifolii, described from Central Europe, because of a very low floristic similarity. The question of whether high arctic vegetation must be accommodated in new syntaxa at higher levels or maintained within units generally described from Central European mountains is an interesting one that cannot be discussed in further detail here.

On these substrates, there are probably also well-developed Luzulion nivalis communities before changing along the topographic gradient into Phippsietum algidae-concinnae. I think that RanunculoOxyrion, described from Scandinavia, is too much a thermophilous alliance to accommodate these snowbeds, and instead I prefer Drepanoclado-Poion alpinae, described from Svalbard.

Clearly acidic substrates have vegetation characterized by Luzula confusa. Again, I reject the position within a more southern alliance, like Saxifragion stellaris-Oxyrion digynae, but instead prefer a more arctic alliance, only provisionally indicated so far.

This syntaxon also covers moderate snowbeds. Late snowbeds are little known (see Elvebakk, 1994). Owing to the dominance of rocks and boulders in such basement rock areas, a Saxicolous community dominated by Andreaea species (A. rupestr is the more common one) is indicated as covering large areas and thus deserves to be mentioned in the legend.

\section{Vegetation of the northern arctic tundra zone}

Figure 2 shows how this zone is distributed along the cooler coasts of Svalbard but is restricted to the sheltered and warmest areas of the northeasternmost island, which is otherwise occupied by polar deserts. Mapping unit $\mathrm{G}$ is developed on acidic substrates and is very rich in mosses and lichens. Lichens form dense carpets, except in areas heavily grazed by reindeer. Dryas octopetala is lacking from the most acidic areas and is of minor importance elsewhere, and Salix polaris is abundant everywhere.

In areas with a circumneutral or alkaline substrate, well-developed Dryas communities occupy only the uppermost parts of the ridges. A relative late snowmelt (as compared with the warmer central areas) leads to the dominance of moderate-snowbed vegetation over large parts of the landscape. This vegetation is characterized by the co dominance of Cetrariella delisei and Saxifraga oppositifolia. However, both these species also have a wide distribution outside the Arctic, and Luzula arctica, although not dominant, is a better choice as a nomenclature species, as in Luzulion nivalis. I do not agree to reduce it to suballiance level as Luzulenion arcticae, because it has a lot of arctic species, and it was originally described as a middle alpine Scandinavian rarity from areas where arctic species were concentrated, and its primary occurrence is in the Arctic and not in alpine areas.

In northernmost Spitsbergen, fine-textured, alkaline Devonian soils become waterlogged in a cold and moist environment, leading to the dominance of late snow-beds. A peculiar aspect of Svalbard is that Poa 
alpina has a much more northern distribution here than elsewhere in the Arctic. It is a very late-melting community, and it has been placed within Drepanoclado-Poion alpinae.

Some coastal areas appear on NDVI maps (e.g., Berge, 1998) as having very dense vegetation cover. These are northern arctic tundra areas that are generally manured and that are mapped as unit $\mathrm{H}$ here. On the flat areas along the western coast of Svalbard, with a topography formed of many small depressions, ponds attract birds, and the accumulated manuring over millennia have produced a large cover of various mire communities. A very typical aspect is mire dominated by tussocks of the amphi-Atlantic Deschampsia alpina, with a discontinuous cover of mire bryophytes and more mesic species, and with no peat accumulation. This is another particular Svalbard community with a position within Eriophorion scheuchzeri. Low temperatures, and perhaps only seasonal water saturation owing to substrate porosity, may explain the lack of peat. It is much more common than peat-producing mires, which have no Carex species, but do have Dupontia fisheri. These mires can be accommodated in Caricion stantis, although Carex aquatilis ssp. stans itself, curiously enough, is almost lacking from Svalbard.

A unique aspect of Svalbard and neighboring Novaya Zemlya is the occurrence of mild water currents, and consequently very large sea-bird concentrations, at higher latitudes than elsewhere in the Arctic. This is also reflected in their numerous nesting sites, producing strong local manuring effects, seen as vividly colored areas, with a mosaic of different communities. Those communities covering the largest areas are moss tundras. Because of the low temperatures, evaporation is so low that a very thin active layer is developed, and the distance from the upper surface to the maximum upper limit of the permafrost is only $25-45 \mathrm{~cm}$. This peculiar habitat ecology maintains a humid but not waterlogged environment in sloping areas with closed bryophyte carpets, most often dominated by Tomentypnum nitens. According to Elvebakk (1994), these areas represent a manured version of Luzulion nivalis, structurally different, but with a very similar floristic composition.

Locally, unit $\mathrm{H}$ also consists of this vegetation, and in eastern Svalbard the occurrence of a similar, but less dense, vegetation can be explained by an accumulative manuring effect through millennia by the local reindeer. They are nonmigratory and concentrated in certain areas where their manuring effects are thought to be significant, accumulated through millennia.

\section{Vegetation of the middle arctic tundra zone}

This zone is restricted to the central parts of the island Spitsbergen and to Bjørnøya. Unit I is the most frequent one, with characteristic Cassiope tetragona-dominated vegetation in zonal positions, with Dryas vegetation on drier ridges, and fens in depressions. Snowbeds cover much smaller areas owing to the higher temperatures and the longer snow-free periods, but thermophilous snowbeds of the alliance RanunculoOxyrion are present (Elvebakk, 1994), with characteristic species such as Trisetum spicatum, Minuartia biflora, and Ranunculus pygmaeus.

Some lowlands in the warmest areas have a dense mire vegetation cover, probably increased through manuring by birds and reindeer. Unit $\mathrm{M}$ is developed on alkaline substrates with bryophytes like Tomenthypnum nitens, Orthothecium chryseon, Catoscopium nigritum and Campylium, Calliergon, and Scorpidium species. Carex subspathacea and C. saxatilis are regular components, but they do not occur in such quantities as Carex species in fens do in other parts of the Arctic.

In the Reindalen area, the substrate is weakly acidic, and oligotrophic mires instead occur with a different composition, with Dicranum, Polytrichum, and Sphagnum species and Warnstorffia sarmentosa in the wettest sites, see unit L. Here, ridge communities are characterized by Hierochloë alpina.

In what are probably most arid areas on Svalbard (no climate data are available) a steppe-like vegetation dominates, similar to the one found near Eureka and Tanquary Fiord in arctic Canada. Instead of having Dryas vegetation, a fine-textured alkaline soil with $\mathrm{pH}$ normally in the 8-8.5 range supports a vegetation characterized by Potentilla pulchella, Poa hartzii, Puccinellia angustata, and several other arctic species. Elsewhere on Svalbard, this vegetation only occurs on small areas where marine sediments are exposed as very dry ridges. The community was recently described as Potentilletum pulchellae (Möller, 2000), and was included by Möller in Arenarion norvegicae, and it was also mentioned by Nilsen \& Elvebakk (subm.). The community was also recently described by Yurtsev (2001) as 'arctic takkyrs,' formed in depressions that are wet in spring, but dry out to form polygon cracks in summer and accumulate sulphides and sulphates at the surface. 
This is a very interesting complex, particularly in arid areas where it is landscape dominant, and not only in small depressions or on small fine-textured ridges. Can we use the words 'arctic steppes' to describe this complex? The Low Arctic steppes known from the amphi-Beringian area and also from Kangerlussuaq/Søndre Strømfjord in Greenland are very well characterized floristically by species like Calamagrostis purpurascens, Carex supina, and many more. Daniëls and others (2000) recently argued convincingly in favor of its status as a separate class, indicating a provisional name. However, the Potentilletum pulchellae is a high arctic version that lacks most of the character species of the former. The relationship between these two complexes remains to be studied. To me they appear to have characteristics similar to the low arctic steppes, and they do not appear to be too saline to deserve the 'arctic steppe' name, although they are floristically distinct. They are certainly different from both Arenarion norvegicae and Caricion nardinae. Elvebakk (1994) indicated a nondescribed alliance, and more studies are planned.

In Woodfjorden, at southern Spitsbergen and at Bjørnøya, middle arctic vegetation is developed where Cassiope is lacking. Instead, Dryas octopetala communities cover large areas, except at Bjørnøya, where even Dryas is lacking. The reasons for the lack of Cassiope may be soil chemistry or oceanity, but other indicators, such as Salix reticulata, are present.

\section{Vegetation of Jan Mayen}

This small and isolated arctic island is volcanic, with a substrate that heavily influences the vegetation formation. It has a strongly oceanic climate, but the temperature sum indicates a position within the middle arctic tundra zone. Elvebakk and Spjelkavik (1995) indicated that the most favorable areas on Jan Mayen, with Empetrum and Sibbaldia procumbens, may belong to the southern arctic tundra zone, but these areas are too small to be included at the present scale. According to Virtanen and others (1997), the most important vegetation complexes are Racomitrium lanuginosum exposed moss heaths, Racomitrium ericoides protected moss heaths, and Anthelia juratzkana snowbeds, cfr. mapping unit N. They did not discuss syntaxonomic positions.

The island is so small that no separate map has been produced here.

\section{Vegetation of northernmost Finnmark}

A narrow strip is delineated as the shortest line north of the mapped northern boreal forest areas by Dahl et al. (1986; figure 4). In this area, Empetrum nigrum ssp hermaphroditum dominates in heath lands, probably as Empetro-Betuletum nanae, even though Betula nana is far less important here than in more continental areas. According to Fremstad (1997), its position is within Loiseleurio-Arctostaphylion in Juncetea trifidi. The oligotrophic mire probably belongs in Caricion canescentis-nigrae. The Salix shrubs are heavily grazed by local reindeer. 


\section{References}

Dahl, E., Elven, R., Moen A., and Skogen, A., 1986, Vegetasjonsregionkart over Norge 1.1,500 000: Nasjonalatlas for Norge. Hovedtema 4. Vegetasjon og dyreliv. Kartblad 4.1.1. Statens Kartverk, Hønefoss.

Daniëls, F.J.A., Bültmann, H., Lünterbusch, C., and Wilhelm, M., 2000, Vegetation zones and biodiversity of the North American Arctic: Berichte Reinh.-Tüxen-Gesellsch., v. 12. p. 131-151.

Elvebakk, A., 1994, A survey of plant associations and alliances from Svalbard: Journal of Vegetation Science, v. 5, p. 791-802.

Elvebakk, A., 1999, Bioclimatic delimitation and subdivision of the Arctic, in I. Nordal, and V. Razzhivin, eds., The species concept in the High North-a panarctic flora initiative: Det Norske Vid.-Akad. I. Mat-Nat. KI. Skr. Ny Ser., v. 38, p. 81112.

Elvebakk, A., Elven, R., and Razzhivin, V., 1999, Delimitaton, zonal and sectorial subdivision of the Arctic for the Panarctic Flora Project, in I. Nordal, and V. Razzhivin, eds., The species concept in the High North A panarctic flora initiative: Det Norske Vid.-Akad I. Mat.-Nat. KI. Skr. Ny. Ser., v. 38, p. 375-386.

Elvebakk, A., and Spjelkavik, S., 1995, The ecology ad distribution of Emperum nigrum ssp. hermaphroditum on Svalbard and Jan Mayen: Nord. J. Bot., v. 15, p. 541-552.

Fremstad, E., 1997, Vegetasjonstyper i Norge: Norsk Inst. Naturforskn. Temahefte, v. 12, 279 p.

Möller, I., 2000, Pflanzensoziologische und vegetationsökologische Studien in Nordwestspitzbergen: Mitt Geogr. Gesellsch., Hamburg 90, Anhang, 202 p.

Yurtsev, B.A., 2001, The Pleistocene 'Tundra-Steppe' and the productivity paradox: the landscape approach: Quatern. Sci. Rev., v. 20, p. 165-174.

Virtanen, R.J., and Eurola, J., 1996, Middle-northern-(oro)arctic vegetation of northern European community types and vegetation gradients: Acta Phytogeogr. Suec.

Virtanen, R.J., Lundberg, P.A., Moen J., and Oksanen, L., 1997, Topographic and altitudinal patterns in plant communities on European arctic islands: Polar Biol. v. 17, p. 95-113.

Winsnes, T.S, 1988, Bedrock map of Svalbard and Jan Mayen, Geological map 1. 1,000 000: Norsk Polarinst. Temakart, v. 3, p. 1-12, 1 map. 


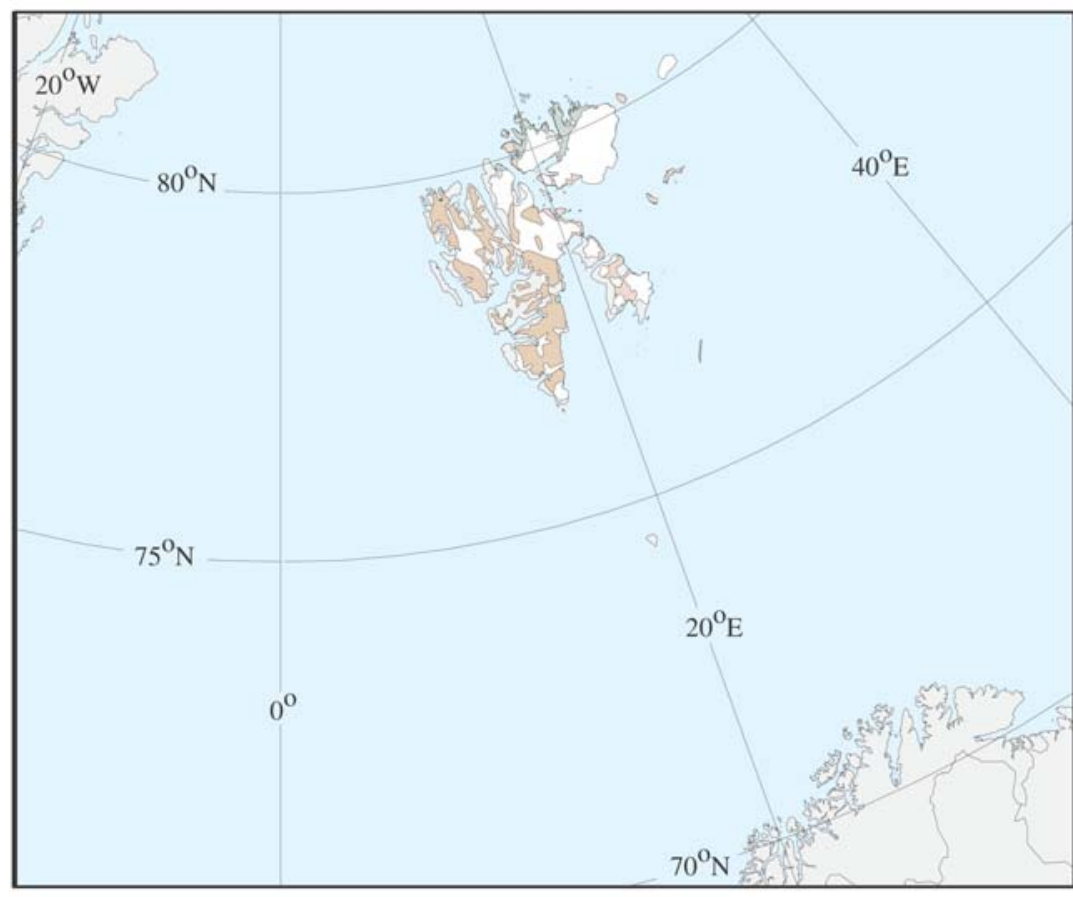

A. Ice caps or glaciated areas with a low, $<20 \%$, cover of polar desert nunataks

B. High mountains/nunataks with Papaver polar desert vegetation, glaciers covering $<80 \%$

C. Acidic polar desert hills/ lowlands with Luzula confus $a$ vegetation

D. Calcareous/circumneutral polar desert hills/lowlands with Papaver vegetation

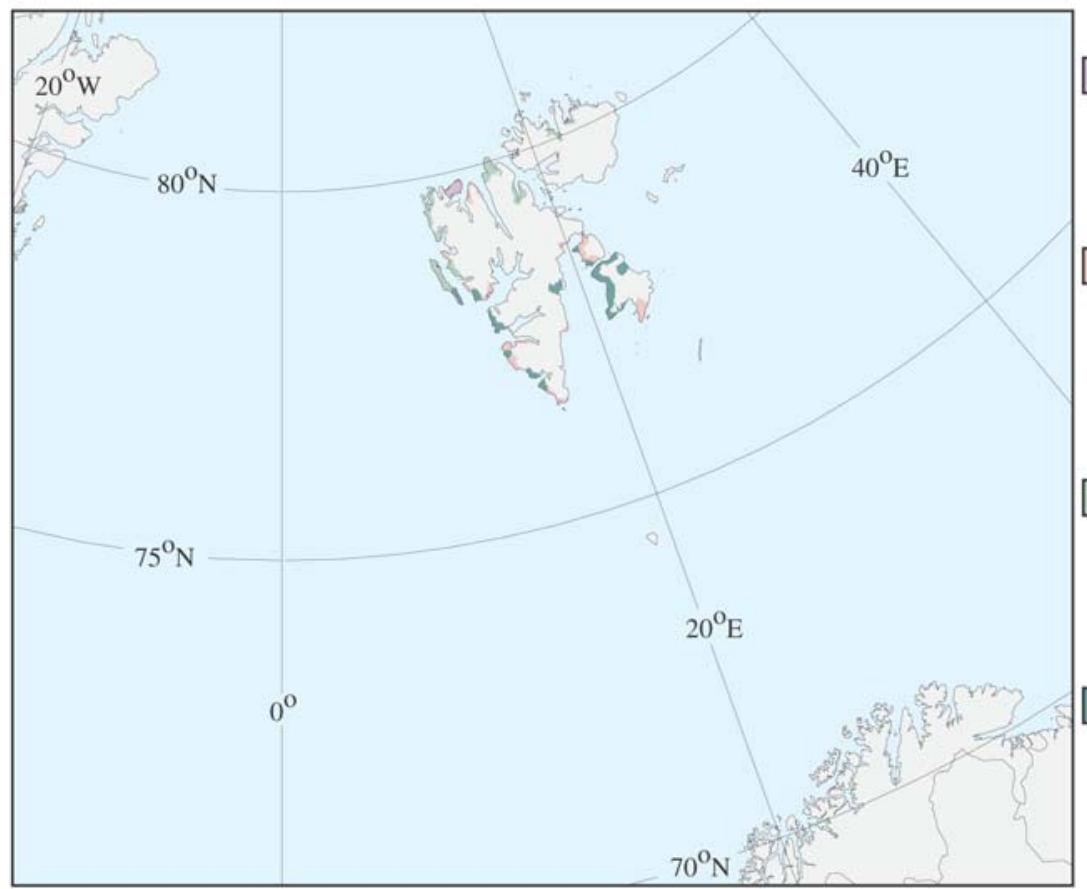

E. Alkaline, fine-textured, northern arctic tundra plains and low hills with Poa alpina vegetation and elements of unit $F$

F. Circumneutral gravelly, northern arctic tundra plains and low hills with Saxifraga oppositifolia, Cetrariella delisei, Dryas octopetala and Deschampsia vegetation

G. Acidic, gravelly, northern arctic tundra plains and low mountains with Luzula confusa vegetation rich in lichens

H. Poorly drained and partly manured, circumneutral, northern arctic tundra plains with Deschampsia alpina and Tomenthypnum nitens vegetation, with elements of unit $\mathrm{F}$

Figure 1 (top). Polar Desert Zone (Zone 1) vegetation on Svalbard.

Figure 2 (bottom). Northern Arctic Zone (Zone 2) vegetation on Svalbard. 


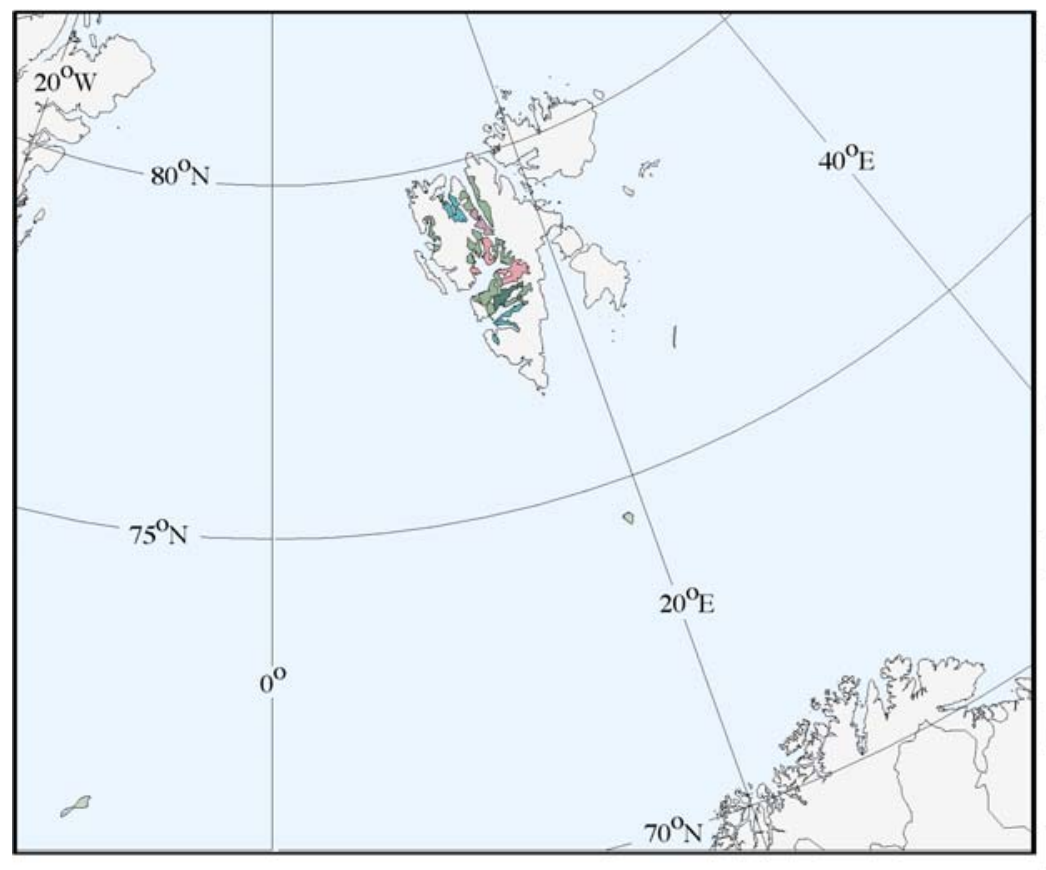

I. Acidic to circumneutral, middle arctic valley and low mountains with Cassiope tetragona vegetation, in mosaic with Dryas octopetala vegetation on ridges, and fens in depressions

J. Acidic to circumneutral middle arctic valleys and low mountains with Dryas octopetala vegetation and fens. Cassiope tetragona is minor or lacking, but other thermophilous species are present

K. Middle arctic and lowland slopes with alkaline, fine textured soil, and an open steppe-like vegetation characterized by $\mathrm{Po}$ tentilla pulchella and Poa hartzii

L. Middle arctic lowland valley bottoms with weakly acidic mires with Dicranum and Sphagnum in mosaic with Hierochloe alpina ridges and Cassiope tetragona vegetation

M. Middle arctic lowland valley bottoms with calcareous fens in mosaic with ridges with Dryas octopetala vegetation

$\mathrm{N}$. Oceanic middle arctic vegetation, without Cassiope or Dryas. Salix reticulata and exposed moss heaths with Racomitrium spp.

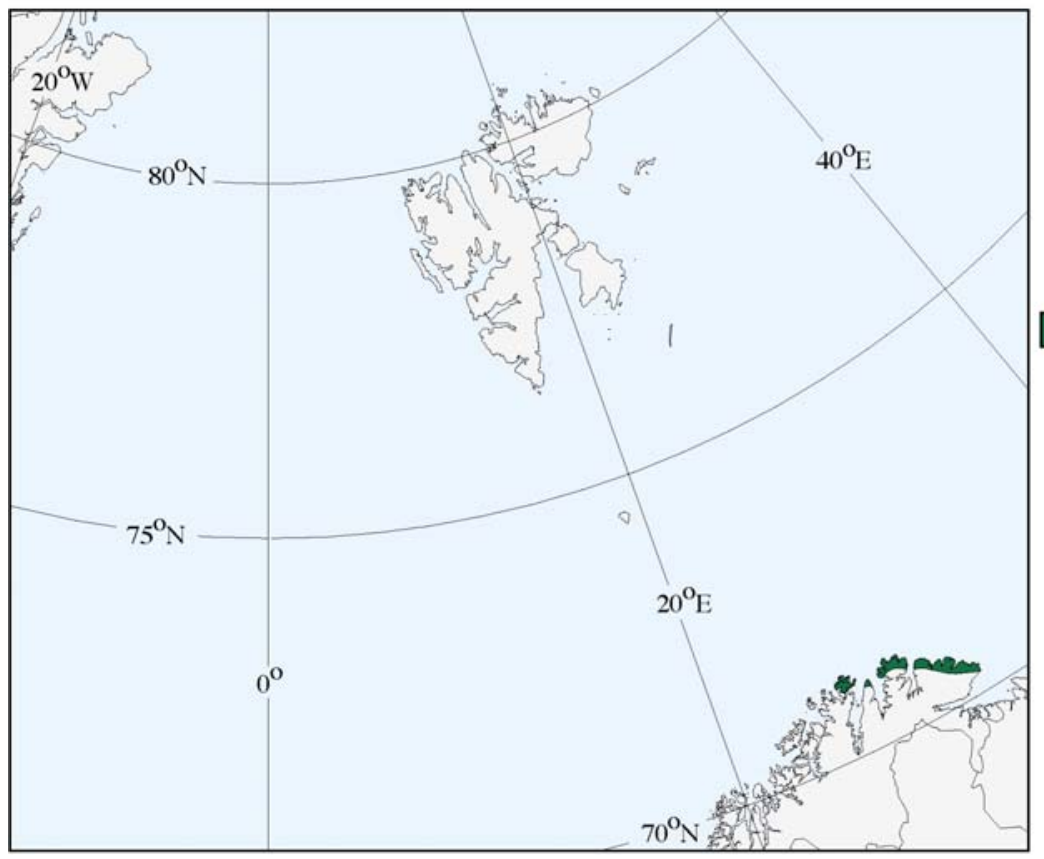

O. Arctic shrub tundra on

coastal oligotrophic sandstones in low mountains, dominated by Empetrum heathlands with Eriophorum angustifolium mires bordered by Salix glauca thickets.

Figure 3 (top). Middle Arctic Tundra Zone (Zone 4) vegetation on Svalbard.

Figure 4 (bottom). Arctic Shrub -Tundra Zone (Zone 5) vegetation on Svalbard . 


\title{
A HIERARCHICAL APPROACH TO MAPPING SOUTHWEST ARCTIC ALASKA
}

\author{
C.J. Markon \\ Raytheon Corp. \\ USGS EROS Alaska Field Office, \\ Anchorage, AK, USA \\ E-mail: markon@usgs.gov \\ S.S. Talbot \\ U.S. Fish and Wildlife Service, \\ Anchorage, AK USA \\ E-mail: Stephen_Talbot@fws.gov
}

The current mapping project produced an integrated landscape vegetation map database of the southwest arctic Alaska biome that portrays dominant plant communities and associated biophysical features with sufficient detail to be useful for global modeling efforts. Totally automated classification approaches using only remotely sensed data are not possible for this type of map, so manual image interpretation and integrated mapping procedures were used. Data layers included a circumpolar AVHRR false-color-infrared image and normalized difference vegetation index map (circa 1993 and 1995), vegetation maps derived from LANDSAT imagery, digital elevation models, and a number of manually produced maps showing bedrock and surficial geology, soils, ecosystems, phytogeographic zones, and floristic provinces.

Mapping procedures used a three-level hierarchical approach. The first level corresponded to a phytogeographic subzone and floristic provinces within the Arctic commonly used in Russia. The phytogeographic subzone boundaries are controlled by summer temperatures along a north-south gradient while floristic provinces correspond to a major east-west floristic variation. The second level used knowledge of bedrock and parent materials to subdivide the first-level units into smaller regions on the basis of parent material chemistry; mainly regions of acidic, nonacidic, and saline materials. At the third and finest level, physiographic features (mountains, hills, plains, river floodplains, water bodies, ice fields) are used to subdivide the map further. Within these units, the dominant plant community types were described using look-up tables to identify the likely dominant plant communities within each map unit, along with estimates of plant biomass and productivity derived from published literature sources. 


\section{APPENDIX A}

\section{ZONAL DISCUSSION}

Date: $\quad$ May 24, 2000

To: $\quad$ Prof. Inger Nordal and Vladimir Yu. Razzhivin (Editors)

The Species Concept in the High North - A Panarctic Flora Initiative

From: Prof. D.A. Walker

Institute of Arctic Biology, University of Alaska Fairbanks

Fairbanks, AK, USA 99775-7000,907-474-2460, FAX 907-474-6967, ffdaw@uaf.edu

Re: $\quad$ Response to Elvebakk's proposal for zonal subdivision of the Arctic: Why the current Russian concept of 'polar desert' is inappropriate for North America

Dear Editors:

The recent publication of Arve Elvebakk's article "Bioclimatic delimitation and subdivision of the Arctic" is a valuable contribution that needs to be seriously considered for several ongoing biodiversity, modeling, and mapping projects that require bioclimatic subdivision of the Arctic. The Circumpolar Arctic Vegetation Mapping (CAVM) project is keenly interested in this effort. As Principal Investigator for the CAVM, I feel it is necessary to comment on some of Elvebakk's points. I wish to keep this an academic debate because Arve and I are good friends. In most respects I applaud his effort to redefine the zonal boundaries and to sort through the maze of terminology that has been used to label the zones. However, Elvebakk's paper presents primarily a Norwegian perspective. A North American viewpoint also needs to be considered. Here I will restrict my comments to the use of the terms 'polar desert' and 'tundra.' I will argue that both the Panarctic Flora (PAF) and CAVM projects should use a neutral set of labels for the subzones.

A fundamental problem for the CAVM is how to characterize the transitions in vegetation that occur across the roughly $10^{\circ} \mathrm{C}$ mean-July-temperature gradient from the tree line to the coldest parts of the Arctic. Boris Yurtsev was one of the initiators of the CAVM project, as well as the PAF project, and his phytogeographic subdivisions have heavily influenced the members of both groups (Yurtsev, 1994). Both projects have agreed that the Russian zonal approach is a logical one that provides the most hope for an international consensus to subdivide the Arctic. Both groups have also agreed that a five-subzone version of this approach describes the major variations along the climate gradient. The major problem is how to name the subzones. The different ways in which the terms 'polar desert' and 'tundra' have been used in Eurasia and North America make it very difficult to see a resolution that will please all groups involved in the CAVM. At the end of my argument, I present a set of subzone labels that avoids the problems with existing sets of terminology. This approach uses the growth forms of the woody component of the vegetation. For the record, I would like to see this response published in the next summary of PAF proceedings.

\section{Why we should not use the term 'polar desert' for the northernmost bioclimatic subzone.}

I have two basic arguments against the use of the term 'polar desert' for the northernmost subzone. The first argument is that the term has a very different meaning in North America than in Eurasia. The second argument is that the term 'desert' is not a good descriptor for the vegetation in this bioclimatic subzone.

1. Elvebakk reviews the history of the Russian terminology, but does not comment on a curious element of Yurtsev's latest attempt at zonation terminology, i.e., his abandonment of the term 'polar desert' to label his coldest northernmost phytogeographic subzone. Instead, Yurtsev labels it the 'High Arctic 
tundra subzone.' The term 'polar desert' had been used in nearly all the previous Russian subdivisions. So why does Yurtsev break with Russian tradition by not using the term 'polar desert?' Although I have not asked Boris this question directly, I believe it is because he recognized two things: (1) There is a basic incompatibility between the Russian and North American usage of this term. (2) There are large areas on fine-grained zonal sites in this northernmost subzone where the vegetation is not desertlike, but instead more continuous, i.e., more tundralike. Unfortunately, he used the term 'High Arctic' which causes other problems in North America, as will be mentioned below.

In North America, the works of John Tedrow and Larry Bliss redefined the meaning of 'polar desert' from that which is presently used in Russia. Tedrow, an American soil scientist, was heavily influenced by the Russian literature. Although Tedrow provides a thorough review of the Russian geobotanical and pedologic zonation schemes in his book Soils of the Polar Landscapes (Tedrow, 1977), he arrives at an endpoint that is quite different from any of the current Russian approaches. He defined 'polar desert,' 'subpolar desert,' and 'tundra' pedologic zones. These more or less followed Polunin's High-, Middle-, and Low-Arctic boundaries. Even though he used the terms polar desert and tundra to describe his zones, neither term was equivalent to the present-day Russian usage. His polar desert was defined on the basis of desert soil processes, which operate in extremely cold and dry climates. Tedrow also defined specific polar desert soils, which are characteristically very well drained, often with gravelly desert pavements, little organic matter, and salt encrustations. Polar-desert soils predominated in his Polar Desert Zone. His 'polar desert zone' included all of Ellesmere, Axel Heiberg, Devon, Cornwallis, and Bathhurst Islands, an area much larger than Yurtsev's or Alexandrova's northernmost subzone. Mean July temperatures in many areas of Tedrow's 'polar desert' can be much warmer than $2-3^{\circ} \mathrm{C}$, which is the temperature often used as the southern limit of the Russian polar desert.

Such a concept does have precedent in the Russian literature. B.N. Gorodkov, whom many consider the father of the polar desert concept, distinguished three subzones within his 'arctic desert.' The sourthernmost included abundant prostrate dwarf shrubs (Salix arctica, S. polaris, Dryas punctata). In other words, Gorodkov's original concept was closer to the polar desert of Tedrow and Bliss. Vera Alexandrova later restricted the 'polar desert' concept to the northernmost of Gorodkov's subzones, an herb-moss arctic desert with an extremely poor angiosperm flora. The present-day Russian concept of 'polar desert' is based largely on 12 criteria used by Alexandrova (1980, p. 145-150). She stressed that this region corresponds almost completely with Steve Young's floristic Zone 1 (Young, 1971; Alexandrova, 1980). Important characteristics of this zone include a complete lack of woody species, sedges, and Sphagna, absence of peat in wetlands, and a predominance of bryophytes, crustose lichens, and blue-green algae, with a mixture of scattered cushion-forming herbaceous species. The total plant species in local floras within Young's Zone 1 is generally less than 60, and the total summer warmth index (sum of mean monthly temperatures greater than $0^{\circ} \mathrm{C}$ ) is less than $6^{\circ} \mathrm{C}$.

Bliss further departed from the Russian concepts by applying the term 'polar desert' broadly to barren arctic landscapes throughout the Canadian High Arctic islands. He does not use 'polar desert' in a zonal sense at all, but more as a landscape descriptor. Bliss has only two zones, the High Arctic and the Low Arctic. Thus the High Arctic of Bliss is much larger than the High Arctic Tundra of Yurtsev. Within the High Arctic there are mires, polar semideserts, and polar deserts. These are further divided into vegetation types based on dominant plant growth forms. As such, the term 'polar desert' describes huge poorly vegetated areas of the Canadian Arctic. These areas sometimes (but not always) have water deficits, and less importance is placed on their floristic aspects than on the plant physiognomy. These were often areas on coarse-grained sediments at high elevations. This is unlike the Russian concept of polar deserts. In the Russian concept, the term was based on the zonal vegetation, which occurs on fine-grained sediments at or near sea level. In summary, Bliss's concept of polar desert was much broader than the Russian concept. It was based to a large extent on Tedrow's ideas of polar desert soils and their strong correspondence with sparsely vegetated landscapes. The concept was primarily a physiogonomic one that was used to describe landscapes at high and low elevations on zonal and nonzonal sites. It extended into much warmer areas than the Russian concept and was only weakly tied to floristic criteria. This is in contrast to the Russian concept which, through the influence of Alexandrova, Young and Yurtsev, and others, developed strong floristic criteria for 'polar desert' delimitation.

Many climate and vegetation-change modelers today use maps depicting tundra and polar desert (Holdridge, 1947; Walter, 1979; Olson et al., 1983; Cramer, 1997), but the polar desert regions on all of these maps are closer to the concept of Tedrow and Bliss. They depict broad regions of northern Canada as 
desert (including Bliss's 'polar desert' and 'polar semidesert'), rather than a narrow coastal strip and the few islands in the northwestern Canadian Archipelago as delimited on Russian zonal maps. At this point, it appears unlikely that the Europeans will accept a broad delimitation of the polar desert, nor is it likely that Americans will accept an extreme restriction of the concept to the northernmost bioclimatic subzone.

2. My second argument against the use of the term 'polar desert' as a bioclimatic subzone is that this subzone is often climatically less desert like than the adjoining subzone. Numerous studies have shown that this subzone is primarily due to oceanic phenomena. Recent reevaluations of the 'polar desert' areas in northern Greenland and the Taimyr Peninsula have confined the subzone to the coastal fringes (Bay, 1997; Razzhivin, 1999). Similarly, during the 1999 Canadian CAVM transect, we saw that the interior areas of the larger Canadian islands were drier and more desertlike than the cold coastal margins. The colder temperatures at the coast (due to fog and the ice covered seas) cause a later snowmelt, and evapotranspiration is lower, promoting a more moist situation. Many placor areas on fine-grained sediments in the coldest regions of the Canadian Arctic are well vegetated, whereas the warmer more continental inland areas are more desertlike. Yurtsev (1994) commented on tundra-like conditions within the coastal fringe in northern Ellesmere Island. On Amund Rignes Island, we encountered large areas of meadowlike vegetation growing on mesic fine-grained sediments in the vicinity of Stratigrapher Creek. Slides I've seen from Irina Safronova from the 'polar desert' in Russia (New Siberian Islands, Yushakova Island, Bolshevik Island, and Cape Chelyuskin) show similar vegetation. The cold moist conditions near the coast keep the soils on zonal sites in a continuously moist condition. Alexandrova (1980) comments on the 'oceanic, cryo-humid climate' in the vicinity of the Barents Sea, and the resulting abundant cryptogam cover. Christian Bay notes that the coastal fringe of northeast Greenland, where the so-called 'polar desert' occurs, is foggy and considerably moister than the inland areas (Bay, 1997). About $200 \mathrm{~mm}$ of moisture occur at the coast compared with ca. 25-mm inland. Although arid saline conditions can be locally found on the drier portions of toposequence, placor areas on fine-grained soils are moister and often more meadowlike than the term 'desert' implies. Last summer, on Axel Heiberg Island in the vicinity of Expedition Fiord, we saw that Yurtsev's boundary is too far inland. In fact, there is no 'polar desert' even at nearby Cape Lavelle, which juts into the arctic ice pack. The interior areas of the larger islands in the Canadian Archipelago, Greenland, and elsewhere are sunnier, warmer, and have the woody plants and floras typical of the more southern subzones. Pictures of continental inland areas of Peary Land, Ellesmere, Cornwallis, Melville, Bathhurst, and Devon Islands depict extremely arid desert landscapes, but these areas are not within the Russian concept of the 'polar desert.'

The northernmost subzone probably covers much less than the 4.6 percent of the Arctic depicted on Yurtsev's (1994) map because it is primarily a coastal phenomenon. Despite its small size, there are several good reasons for portraying this subzone on global maps: (1) The subzone represents the endpoint along the climatic gradient. The low temperatures, not aridity, control the extremely low stature of the vegetation. (2) The area of the subzone is large enough to portray on global maps. (3) Similar 'oropolar desert' landscapes occur at higher elevations in all the arctic subzones owing to adiabatic cooling. These create complex mosaics of 'polar desert' landscapes that may cover larger areas than their low-elevation zonal counterparts (Bliss and Matveyeva, 1992). (4) There is a great deal of research that has shown this subzone to have distinctive ecosystem properties (Bliss and others, 1984; Alexandrova, 1988; Chernov and Matveyeva, 1997). (5) This subzone could have special significance for global change because even small changes in temperature at this extreme will result in major biological changes.

In summary, although there is good reason to recognize the existence of this northernmost subzone, there is also good reason not to use the term 'polar desert' to describe it. There are huge conflicts in the meaning of the term in Eurasia and North America. To limit 'polar deserts' to the extreme coldest bioclimatic region in North America would cause confusion and would be inappropriate and inaccuratedespite the long use of the term in this context in Eurasia.

\section{Need for an expanded concept of tundra}

There are equally troublesome problems with the term 'tundra.' Elvebakk reviews the origin of the term and argues for a definition that makes dwarf-shrubs a mandatory component of 'tundra.' This definition excludes the coldest 'polar desert' subzone because woody plants are absent here, but it includes the other four subzones. This follows the tradition of current Russian zonal approaches and some other phytogeographers. However, the actual distinction between 'polar desert' and 'tundra' is not clear. As mentioned above, Gorodkov extended the original concept of polar desert into areas that are now 
considered 'tundra,' and much, if not most, of the area in Elvebakk's 'northern arctic tundra' subzone in the Canadian Arctic is extremely barren and desert-like. In North America, Tedrow and Bliss confine 'tundra' to the "vegetation of the Low Arctic where plant cover is nearly complete and where woody species, sedges and grasses predominate" (Bliss, 1997). Bliss's concept is different from the Russian concept because his explicitly excludes the Dryas-dominated cushion-plant vegetation that covers large areas of the Russian 'Arctic tundra.' What Bliss describes as 'polar semidesert' would be considered part of the 'Arctic Tundra' subzone of Alexandrova and Yurtsev and the 'Typical Tundra' of Matveyeva (Matveyeva, 1998).

Elvebakk's 'tundra' zones also have a problem of consistency, He recognizes three 'tundra' zones: 'northern arctic tundra,' 'middle arctic tundra,' and 'southern arctic tundra.' He also has an 'arctic shrub tundra zone' south of the 'southern arctic tundra zone.' If these terms were taken out of context, a reader would have no way of knowing that the 'southern arctic tundra' is not the southernmost arctic tundra subzone. Such geographic labels should not be mixed with growth form and climatic terms, unless it is done in a consistent manner.

Where to draw the limits of the tundra zone has plagued phytogeographers, and many, including me, consider the only logical boundaries to be the tree line and the permanent-snow line. This would include all of the treeless alpine and arctic areas beyond the climatic tree line worldwide. The definition of Patrick Webber is perhaps the cleanest:

[T] undra is defined as the treeless regions beyond climatic timberlines in the north (arctic tundra) and on high mountains (alpine tundra). (Webber, 1974)

This definition is more than the original Lapland 'tunturi,' meaning treeless plains, but less than the expanded meaning of the International Biological Programme (IBP) (Wielgolaski, 1972), which also includes oceanic moorland areas in cool temperate climates. Thus the concept requires the dominance of cryophyte plants. There are many other prominent precedents that unite cold treeless areas under the title 'tundra' (Fuller and Kevan, 1970; Ives and Barry, 1974; Löve and Löve, 1974; Wielgolaski, 1997). In a paper presented at the 1994 CAVM meeting in St. Petersburg, Yurtsev calls the Arctic the 'Tundra Zone.' F.E. Wiegolaski's recent book, Polar and Alpine Tundra, logically unites the huge worldwide diversity of tundra. There is a good North American precedent for the broader definition of tundra in the Glossary of Landscape and Vegetation Ecology for Alaska:

Tundra - (1) From the Finnish "tunturi," meaning a treeless plain and describing the landscape beyond the cold limits of tree growth. (2) A cold climate landscape having a vegetation without trees. The absence of trees is caused by a complex of conditions that is ultimately related to regional climate. This regional aspect distinguishes tundra from treeless bogs and similar local areas without trees due to edaphic extremes in areas that otherwise support a forest cover. (3) The landscape beyond the limits of tree growth, both to the north and west of treeline Alaska and at elevations above treeline on mountains. (4) The so-called "barren ground" north of the circumpolar coniferous forests. (Gabriel and Talbot, 1984)

Gabriel and Talbot (1984) further define various types of tundra, on the basis of the dominant growth forms; for example, dwarf shrub tundra, herbaceous tundra, mat and cushion tundra, sedge-grass tundra, shrub tundra, and tussock tundra. This broad definition of tundra thus eliminates the need for the term 'polar desert' and allows the entire cold treeless biome to be united and its vegetation types and subzones to be distinguished solely on the basis of dominant or characteristic plant growth forms.

\section{Names for the arctic subzones}

The most neutral approach to label the arctic subzones is to use alphabetic or numeric designations. This was accepted as a temporary solution at the final meeting of the PAF at the Centre for Advanced Study, Oslo, in 1999 (Elven, 1999), where the subzones were labeled A to E (Elvebakk et al., 1999). I also reluctantly accept this approach as an interim solution until a consensus can be reached on a set of terminology that is agreeable to all the circumpolar countries. The CAVM is currently using numeric designations 1 to 5 to keep them distinct from those of the PAF and so to allow modification of the subzonal boundaries. I would also suggest a cross-walk between the alphanumeric labels and other existing zonation systems. This would allow countries with strong geobotanical traditions to use their own systems. It would also allow users to choose from several sets of terminology to best fit their needs. It also may lead to eventual consensus on one set among those listed. 
I would suggest including within this cross-walk a system based on plant growth forms. Such an approach was developed during a workshop in Potsdam in 1998. The goal of the workshop was to simulate climate and environmental changes since the last glacial maximum and to develop paleovegetation maps of the Arctic. The effort uses the BIOME model developed at the Potsdam Institute of Climate Impact Research (Prentice et al., 1993). The modeling group in Potsdam had extensive experience with worldwide vegetation and determined that names based on dominant or characteristic plant growth forms or plant functional types were the most descriptive and avoided emotional conflicts between different groups over naming bioclimatic zones. This approach is a further refinement and simplification of earlier growth-formbased classification schemes (Holdridge, 1947; Fosberg, 1970; Mueller-Dombois and Ellenberg, 1974).

The tundra zone thus could be divided into the following subzones along the same boundaries suggested by Elvebakk et al. (1999):

Subzone 1: Cushion-forb subzone (Papaver radicatum s.1.)

Subzone 2: Prostrate dwarf shrub subzone (Dryas spp., Salix arctica/ S. polaris)

Subzone 3: Hemiprostrate dwarf shrub subzone (Cassiope tetragona)

Subzone 4: Erect dwarf shrub subzone (Ledum decumbens, Vaccinium uliginosum, Salix lanata)

Subzone 5: Low shrub subzone (Betula nana s.l., Alnus crispa, Salix spp.)

The terminology is based on the stature of the woody component in the uppermost layer of the plant canopy on zonal sites, except in Subzone 1 where there are no woody plants. The stature and size of the woody shrub component is highly correlated with the summer warmth (Walker, 1987). These names are only labels and are not meant to fully characterize the full suite of common growth forms of zonal plant communities. Such names would be far too long. This information could be contained in expanded legends and accompanying tables. The names do give a mental picture of the dominant or characteristic plants. The plant species names in parentheses can be added to give a clearer idea of the units. This approach is similar to several previous small-scale maps in the Arctic, such as the growth form approach used by Sylvia Edlund in the Canadian Arctic Islands (Edlund, 1990; Edlund, 1996). The approach suggested here has been proposed earlier (Walker, 2000, in press), but with only four subzones. Here, Subzone 3 has been added. This subzone corresponds to the Cassiope tetragona zone on the map of Svalbard (Brattbakk, 1986). In this subzone, the hemiprostrate shrub, Cassiope tetragona is characteristic of mesic sites in Svalbard, Greenland, and acidic soils on Baffin Island, but not on the alkaline soils in the western Canadian Arctic. In the alkaline areas, Dryas integrifolia and Salix arctica are dominant, and Cassiope is primarily restricted to shallow snowbeds.

The proposed approach is a logical, consistent, and neutral approach based on the actual vegetation. It avoids the semantic problems associated with the terms 'polar desert' and 'tundra.' It is, however, difficult to reach a consensus on terminology because of strong traditions in each of the circumpolar countries. One criticism of this approach is that the divisions within the dwarf-shrub growth form (prostrate, hemiprostrate, erect) may be too confusing. This does not need to be a problem as long as these concepts are clearly defined. We have to be sensitive to all the various traditions. For now, the truly neutral approach of alphanumeric codes may be the best until all the approaches can be thoroughly reviewed by all the countries. Consensus regarding zonation labels is not necessary within the CAVM at this time while we carry on with the more critical work of the actual mapping. The approach of using letters or number titles can suffice for now. I would encourage the PAF also to continue to treat the zonation nomenclature in a similar neutral fashion.

With best regards, Skip Walker 


\section{References}

Alexandrova, V.D., 1980, The Arctic and Antarctic: Their Division into Geobotanical Areas: Cambridge, Cambridge University Press.

Alexandrova, V.D., 1988, Vegetation of the Soviet Polar Deserts: New York, Cambridge University Press.

Bay, C., 1997, Floristical and ecological characterization of the polar desert zone of Greenland: Journal of Vegetation Science, v. 8, no. 5, p. 685-696.

Bliss, L.C., 1997, Arctic ecosystems of North America, in Wielgolaski F.E., ed., Polar and Alpine Tundra: Amsterdam, Elsevier, p. 551-683.

Bliss, L.C, Matveyeva, N.V., 1992, Circumpolar arctic vegetation, in Chapin F.S., III, ed., Arctic ecosystems in a changing climate: an ecophysiological perspective: San Diego, Academic Press, Inc., CA, p. 59-89.

Bliss, L.C., Svoboda, J., Bliss, D.I. , 1984, Polar deserts, their plant cover and production in the Canadian High Arctic: Holarctic Ecology, v. 7, p. 305-324.

Brattbakk, I., 1986, Vegetation Regions - Svalbard and Jan Mayen: Norsk Polarinstitutt/MAB.

Chernov, Y.I., Matveyeva, N.V., 1997, Arctic ecosystems in Russia, in Wielgolaski F.E., ed., Polar and Alpine Tundra: Amsterdam, Elsevier, p. 361-507.

Cramer, W., 1997, Modeling the possible impact of climate change on broad-scale vegetation structure: examples from northern Europe, in Oechel W.C., ed., Global Change and Arctic Terrestrial Ecosystems, Ecological Studies: New York, Springer, p. 312-329.

Edlund, S., 1996, Legend for vegetation of Canadian arctic islands and adjacent mainland, in Walker, D.A., and Markon, C.J., eds., Circumpolar Arctic Vegetation Mapping Workshop, St. Petersburg, Russia: U.S. Geological Survey, OpenFile Report 96-251.

Edlund, S.A., 1990, Vegetation, Central Queen Elizabeth Islands, District of Franklin, Northwest Territories, Map 1755A: Geological Survey of Canada.

Elvebakk, A., Elven, R., Razzhivin, V.Y., 1999, Delimitation, zonal and sectorial subdivision of the Arctic for the Panarctic Flora Project, in Nordal, I., and Razzhivin, V.Y., eds., The Species Concept in the High North - A Panarctic Flora Initiative: Oslo, The Norwegian Academy of Science and Letters, p. 375-386.

Elven, R., 1999, Summary of the final meeting of the Panarctic Flora Year at the Centre for Advanced Study, 0slo, 31.0505.06.99, in Nordal, I., and Razzhivin, V.Y., eds., The Species Concept in the High North - A Panarctic Flora Initiative: Oslo, The Norwegian Academy of Science and Letters, p. 363-373.

Fosberg, F.R., 1970, A classification of vegetation for general purposes, Guide to the check sheet for IPB areas, IBP Handbook: Blackwell Scientific Publications, Oxford and Edinburgh, p. 73-120.

Fuller, W.A., Kevan, P.G., eds., 1970, Proceedings of the Conference on Productivity and Conservation in Northern Circumpolar Lands: International Union for Conservation of Nature and Natural Resources (IUCN) Publication No. 16.

Gabriel, H.W., and Talbot, S.S., 1984, Glossary of landscape and vegetation ecology for Alaska: Technical Report 10, Bureau of Land Management, U.S. Department of the Interior, Anchorage, AK.

Holdridge, L.R., 1947, Determination of world plant formations from simple climatic data: Science, v. 105, p. 367-368.

Ives, J.D., and Barry, R.G., 1974, Arctic and Alpine Environments: London, Methuen.

Löve, A., and Löve, D., 1974, Origin and evolution of the arctic and alpine floras, in Ives, J.D., and Barry, R.G., eds., Arctic and alpine environments: Methuen, London, p. 571-603.

Matveyeva, N.V., 1998, Zonation in Plant Cover of the Arctic: Russian Academy of Sciences, Proceedings of the Komarov Botanical Institute, No. 21. (In Russian).

Mueller-Dombois, D., and Ellenberg, H., 1974, Tentative physiognomic-ecological classification of plant formations of the earth, in Mueller-Dombois, D. , Ellenberg, H., eds., Aims and methods of vegetation ecology: New York, John Wiley and Sons, p. 466-498.

Olson, J.S., Watts, J.A., and Allisonm L.J., 1983, Carbon in live vegetation of major world ecosystems, Pages in Environmental Science Division: Oak Ridge National Laboratory, ORNL-5862.

Prentice, I.C., Sykes, M.T., and Cramer, W., 1993, A simulation model for the transient effects of climate change on forest landscapes: Ecological Modelling, v. 65, p. 51-70. 
Razzhivin, V.Y., 1999, Zonation of vegetation in the Russian Arctic, in Nordal, I., and Razzhivin, V.Y., eds., The Species Concept in the High North - A Panarctic Flora Initiative: Oslo, The Norwegian Academy of Science and Letters, p. 113-130.

Tedrow, J.C.F., 1977, Soils of the Polar Landscapes: New Brunswick, Rutgers University Press, NJ.

Walker, D.A., 1987, Height and growth ring response of Salix lanata ssp. richardsonii along the coastal temperature gradient of northern Alaska: Canadian Journal of Botany, v. 65, p. 988-993.

Walker, D.A., 2000, in press, Hierarchical subdivision of arctic tundra based on vegetation response to climate, parent material, and topography: Global Change Biology.

Walter, H., 1979, Vegetation of the Earth and Ecological Systems of the Geo-Biosphere: 2nd ed., New York, SpringerVerlag.

Webber, P.J., 1974, Tundra primary productivity, in Ives, J.D., and Barry, R.G., eds., Arctic and Alpine Environments: London, Methuen, p. 445-473.

Wielgolaski, F.E, 1972, Vegetation types and plant biomass in tundra: Arctic and Alpine Research, v. 4, p. 291-305.

Wielgolaski, F.E.E., 1997, Polar and Alpine Tundra: Amsterdam, Elsevier.

Young, S.B., 1971, The vascular flora of St. Lawrence Island with special reference to floristic zonation in the arctic regions: Contributions from the Gray Herbarium, v. 201, p. 11-115.

Yurtsev, B.A., 1994, Floristic division of the Arctic: Journal of Vegetation Science, v. 5, no. 6, p. 765-776. 
Date: 26 May 2000

To: $\quad$ Skip Walker $<$ ffdaw@aurora.uaf.edu

From: Arve Elvebakk<Arve.Elvebakk@ibg.uit.no

Subject: Response to Skip Walker's zonation debate letter

First I should say that I appreciate this discussion including Skip's latest letter. I also try to be open and evaluate arguments that I find convincing, but also to argue against less convincing proposals. The better discussion we have among our group of arctic botanists, the better result will come out, in one way or the other. Skip is now having his views published in 'Global Change Biology,' and mine were printed in the PAF Proceedings. However, the debate must continue, and I allow myself to give a comment to Skip's letter, also since some of you probably do not have the PAF proceedings at hand.

There is not space to treat all aspects here, so my comment will mostly focus critically on Skip's proposal. But of course I support that his system will be included along with other alternatives in future treatments. Here are my comments to his proposal:

\section{It is not neutral}

a) It presupposes a particular tundra definition over the traditional one. Let me illustrate the classical definition in this practical way. We are standing in some varied landscape somewhere in the central part of the Arctic, and we are 'walking out on the tundra.' Often we can meet with large poorly vegetated areas like boulder fields with little soil, steep unstable slopes, wide river beds due to changing courses, young moraines, etc., in addition to more or less closed vegetation with cryptogams, herbs and dwarfshrubs/shrubs. These are normally developed on flat or rolling terrain, and I associate 'walking on the tundra' with being on such sites; i.e., with the physiognomy. Aleksandrova (1980) adopted 'tundra' at two levels. The 'nucleus' is what I briefly described above, what she called 'tundra type of vegetation.' But the reality is that a landscape is mosaiclike with different landforms with their habitats and corresponding vegetation, and she adopted the 'tundra region' for such landscapes where the 'tundra type of vegetation' is present (but only as one of several elements).

Particularly in North America, and by authors influenced by North Americans like Wielgolaski, a broad definition of tundra as 'all treeless cold areas,' to put it briefly, was established. I think we can keep away from this problem by dealing with 'arctic tundra' and let the world continue elsewhere with its definitions; it will do so anyway. Therefore I resist adopting the general definitions Skip proposes. One problem with this definition is that it only addresses mountains and the North, but not the southern hemisphere. These areas cover small terrestrial land surfaces, but a variety of landscapes ranging from the most extreme polar deserts, to less extreme versions, to tundra-like areas, and to wind-swept treeless moorlands with definitely a nonpolar climate. It is challenging to characterize these areas. However, most authors accept a polar desert, and the general tundra definition as cited by Skip would include also ice-free Antarctic, which I would find too vague and with low information content. My conclusion is that we should keep to the classical tundra definition, but call it 'arctic tundra' and then leave definitions of alpine and southern hemisphere situations to others.

b) The use of growth-form names is, as far as I have conceived it, mostly a North American tradition related to vegetation types and vegetation map units. In Eurasia species names, phytosociology, or physiognomy is more used. Sylvia Edlund introduced the growth form names (but otherwise treated her zones in a very similar way as done in Eurasia), from vegetation types to zonal units, a practice prolonged by Skip here, but it has no tradition elsewhere, and thus is not neutral as to different traditions.

\section{It is not simple}

Skip's names are abbreviated versions. The full names are 'Cushion-forb subzone (+ possibly Papaver radicatum s.l.) of the arctic tundra (zone),' alternatively 'Cushion-forb arctic tundra subzone,' etc. 
'Cushion-forb subzone' alone has no precision. These names are much too long. Even a short-version like 'hemiprostrate dwarf shrub subzone' is too intricate. And even 'prostrate' as a word is too scientific to me to allow in a name intended for general public use, although there may be a tradition of using more latinized names in English.

I have been looking for simple names that can be used widely and in full context. The different shrub types are classified with too much detail. I do not think even all botanists would agree that Cassiope is a hemiprostrate shrub. In calcareous situations with marginal occurrences, it may appear more depressed than normally, as I saw in some places in Canada, but I do not think this should be referred to in a general zonal sense, although a fifth name is needed in a five-unit system.

\section{It is narrowing the scope of users}

The lignified growth forms relate only to some part of the vegetation of the arctic landscape, and may appear as a system by botanists for botanists. Instead I would favor physiognomy in names, because it has a wider appeal also to a general and nonscientific audience.

\section{Cushion-forb?}

I have some minor comments to this name. A compact growth form is shown by both the graminoids and the forbs (another English/American English name without good counterparts in our languages, and it is also lacking from my English Collins Dictionary), so I do not think 'forb' is a good choice. 'Cushion' needs further definition. I consider the growth form of Silene acaulis (typically absent from this zone) as the best arctic representative of this growth form as conceived globally, but there are some very small plants like Drabas and Minuartias that deserve this name, whereas others are more rosettes or tussocks.

\section{Conclusion}

Skip's proposal does not omit the problem of discussing our different traditions of 'tundra' and 'polar desert,' as it presupposes one definition. Reality is complicated, and we should keep in mind the natural variation along many gradients and have names that can reflect such variation. The biomass is increasing southwards, but it has many local deviations. Some are the landscape-defined habitats I mentioned in 1a. Others are limestone gravel and strongly arid areas. Around Eureka and Tanquary Fiord, the vegetation was very open with drought stress and dominated by what Boris would call 'cryoxerohalophytes' or 'cryahalophytes.' Then we could enter another definition problem. Why can't this be called an arctic steppe? It has certainly nothing to do with a polar desert. Arctic steppes have previously been studied further to the south and characterized by species like Carex supina and Calamagrostis purpurascens. Boris called the small fragments of this floristic element on the Daring Lake eskers, as fragments of 'arctic steppe vegetation,' although this was in a less arid area. The Eureka situation is floristically very different but may represent a more northern parallel.

I mention this, not to initiate another definition discussion about steppes, but to underline that there are different factors determining various levels of plant cover, and they can be described in two levels as Aleksandrova did. For the bioclimatic zonation of the Arctic, I would give priority to temperatures and allow for a variety of habitat/vegetation complexes within each zonal unit. The polar desert concept is related to very low temperatures. Deviations from the general pattern occur. On our low flight above Amund Ringnes Island southwards in Canada last summer, we saw less vegetation cover over vast areas south of the only stop we made there, and then a significant increase at the southernmost area and on the neighboring island to the south. My impression from the trip is that what we saw coincided well with Edlund and Alt (1989).

My attitude now is that we still have to deal with the physiognomic aspects. I should underline that shrub-tundra is a physiognomic aspect, shortened from shrubland-tundra, which I think is a little long. Shrubland does not relate to the various dwarf shrub-forms, but only to those above $40-50 \mathrm{~cm}$, which are much more distinct physiognomically. As to criteria, I tend to continue with our start on a cross-walk table as done at Cambridge Bay (and unpublished for those of you who were not there), featuring many vegetation types, of which both floristics and growth forms that can be extracted, because I think this is a set of criteria that can work both locally and regionally. 
My proposal can be called 'primarily Norwegian' because I am Norwegian and it is now much used in Norway. But it has no long tradition here. Instead the Polunin system dominated here until I modified the system from Aleksandrova in the 1980s. So as to tradition, if our perspective is longer than back to 1985, it is more Russian. 
Date: 26 May 2000

To: $\quad$ Arve Elvebakk <arveelvebakk

From: Skip Walker $<$ ffdaw@aurora.uaf.edu

Subject: The debate goes on

I felt I had to get my views on the zonation scheme in print because there are serious differences in the European and North American approaches to tundra and polar desert, which make common ground difficult. I was hopeful that pointing out these differences would at least give the PAF folks a second opinion. My point was not to interject my scheme as a solution, but instead to encourage the continued use of the alpha or numeric labels until such time that a full debate and possible consensus can be had.

Fred Daniels is here now, and we have had long discussions regarding the whole zonation debate. He has his own version of a scheme, which is somewhat of a compromise between your system and mine. I think we both feel that perhaps Polunin's old High, Middle, Low Arctic is not so bad, and neither is Boris's or Larry Bliss's, or Alexandrova's, or yours if the terminology and context are all understood. In many ways, if we are basically using Boris's subdivisions, then it may make good sense to use the names that he proposed in his latest paper at Latka, rather than developing some hybrid using Norwegian or North American names. I wish Boris were in better health, because I would like to hear how he would label his units now that he has heard all the different viewpoints.

The problem is coming to a middle ground. Fred feels that we will have failed as a group if we don't reach some kind of consensus on the terminology for the bioclimatic subzone before the map is published. I am not so sure this is possible. I am no longer optimistic that we can reach a consensus, but I also feel that consensus on this particular issue is not essential.

For now, I think the alphanumeric labels are probably okay since it is unlikely that we will reach a consensus soon. The map itself will show vegetation units. The zonal names will only occur in the background as an overlay. Right now I am devising a legend for one map that will show dominant growth forms. Another map could show dominant syntaxonomic units. Other maps can show production or other aspects of the vegetation, including zones or floristic sectors, but these could just as easily have letters or numbers, and show the equivalent units in each of the historic zonal systems. I think this will actually be the best approach so that any country can see how its system fits and where there might be problems. The main thing is to have clear descriptions so that the units can be recognized. The names are not important.

Both of us now have our schemes in print, and we both should feel free to use our system for our own purposes and let others judge if ours or some other system is best for their purposes. I have actually enjoyed this debate because it has forced me to make a thorough analysis of the problem. I am not sure we are any closer to a solution than we were in Latka, but we are at least thoroughly versed in the history of the zonation issue. It is important to keep talking and to keep friendly relations because this is the only way that a solution will be found. 
Date: 29 May 2000

To: $\quad$ Skip Walker $<$ ffdaw@aurora.uaf.edu

From: Arve Elvebakk<Arve.Elvebakk@ibg.uit.no

Subject: Re: The debate goes on

Thank you for your nice letter. I would like to express once more that I am neither irritated nor unhappy about this debate, nor do I have any negative feelings against you as a debate partner. It has been necessary and very stimulating. The only hard time was at Daring Lake where we had anticipated reaching a consensus, and I think maybe you, feeling the responsibility as the project leader, were most unhappy when this was not possible, although we tried almost until the plane picked us up.

Afterwards I have been thinking that it was good that we did not force ourselves to some compromise that would lack the consistencies of original alternatives, but would represent a consensus of the day. I think it is better to have several alternatives reflecting different traditions, than it would have been to arrive at a compromise in a late evening when everybody was tired, and would accept it just 'to have peace,' and maybe regret it afterwards. We are a small group, although we have many opinions, but the world around us has even more opinions, and if an outcome of our group is not good enough it will simply not be used. It is my basis for being so critical. It would be possible for our group to use any version and be able to communicate with each other, but the nonbotanic world outside us needs something user-friendly and essential, otherwise it will be neglected. I think we should not overestimate our role as determinants, although we all would like to see one recommended CAVM nomenclature.

I have learned much from this debate. In my mind I have tried to be open, although I may appear stubborn, as I have resisted several of your previous proposals. But this is a matter that has occupied my mind since I wrote my 1985 paper about zonation. And I have been thinking, what is possibly not good about that system, what can be improved? 'Hemiarctic,' yes. But students who experienced this as something new, the management authorities, and our national flora, which likes to cite its abbreviations regarding species' distributions, have easily adopted it. I have also considered adding some additional word into my names of zones $2-4$, but feel that it would make it too intricate.

From the debate, I have learned to focus more on definitions than I initially did. At the present moment, my inclination is, for the CAVM map legend, to briefly state that the initial Russian definitions of tundra and polar desert were so and so, and some alternatives in naming are based on these definitions. Mine is one example. Primarily in North America, both these concepts were much broadened, and different names originate from these different definitions; yours is one example. Then we can state that it is difficult to find a good name compromise, because it is not possible to compromise these definitions, therefore different sets of names are necessary following the different definitions. This is reality, and it is better to face it, state it openly (because not everybody realizes this), than to force us, through voting or other measures, to a compromise that conceals this definition difference. In the meantime, our academic debate can continue on suitable occasions. 
Date: 23 June 2000

From: yurtsev@IK6026.spb.edu (Yurtsev, Boris Alexandrovich)

To: $\quad$ Skip Walker <ffdaw@aurora.uaf.edu, Arve Elvebakk< <Arve.Elvebakk@ibg.uit.no

Subject: zonation

Organization: Komarov Botanical Institute

I have not received the copies of messages with discussions on the Arctic zonation. Among Volodya's zonal novelties, I categorically do not accept referring the coasts of Wrangel Island to (sub)zone C (instead of B). It is the Beringian version of (sub)zone B with quiet development throughout late Cenozoic that permitted some relatively "southern" plants to adapt to a very cold climate (mean July temperature +3.6 degrees $\mathrm{C}$ in Somnitelnaya Bay and 2.4 degrees $\mathrm{C}$ in Rodjer Bay). Both acidic and carbonate rocks are well represented in the island. A south-central enclave of more "southern" in aspect vegetation in the island should be referred to (sub)zone $\mathrm{C}$ enclave despite the presence of very low shrubs in extrazonal sheltered habitats. Volodya's toposequence for southern tundra (subzone E) belongs in reality to large stlanik (sub)zone, which we do not include into the Arctic. I am ready to present a full set of arguments for this. Volodya's version of East Russian zonation was not discussed at our meetings in Oslo before the publication. 
Date: 12 July 2000

From: yurtsev@IK6026.spb.edu (Yurtsev, Boris Alexandrovich)

To:_reidar.elven@toyen.uio.no, Arve.Elvebakk@ibg.uit.no, ffdaw@aurora.uaf.edu

Subject: Re: zonation

Organization: Komarov Botanical Institute

Dear Arve:

Thanks for your good email letter of July 6 !

A few words on the zonal position of Wrangel Island. In my paper in Botan. Zhurnal, 1987 vol. 72, N 11 (pp. 440-441) I included various climatic data for both weather stations on the south coast of Wrangel Island and for Maria Pronchishcheva Bay station in Taimyr where Nadya described a classical subzone B ( II ) situation. It includes mean June, July, and August temperatures, the sum of mean monthly positive temperatures, mean maximal and mean minimal temperatures for VI, VII, and VIII. According to all the above parameters, Somnitelnaya Station is clearly colder in summer than Maria Pronchishcheva Bay, and Rogers Bay with mean July temperature of 2.4 degrees is significantly colder than Somnitelnaya station. The position of Wrangel Island stations at the shore (of Long Strait) is typical of all weather stations in the Arctic (including all Taimyr stations!). Rogers Bay station is situated on sea beach, but Somnitelnaya station is on a high marine terrace with typical placor (=mesic, in this case) vegetation. Approximately at the same distance from the sea shore, a clone of relic true-steppe sedge Carex duriuscula (=prairie $C$. eleocharis!) occurs on a marginal part of the 4-6 m terrace in association with some continental high-arctic halophytes such as Puccinellia angustata, Potentilla pulchella and Gastrolychnis triflora subsp.

wrangelica. No one low shrub species! Some steppe plants (Carex obtusata, Silene repens, Potentilla arenosa, Eritrichium sericeum, etc.) form patches of cryophyte steppe on south-facing bluffs immediately in close neighborhood with Rogers Bay weather station. As to Eriophorum vaginatum "tussocks" in the central parts of the island, they are extremely rare (for example, in the upper reaches of Neizvestnaya River they are completely lacking), are not a true tussock (rather sporadic patches, with arctic plants) typical zone "C" Eriophorum vaginatum community! The great floristic richness of Wrangel Island zone "B" tundra is a florogenetic phenomenon, typical of Beringia where the adaptation of plants to a high-arctic climate was a continual, long-term, gradual process. Comparison of the zonal position of the same species in different (seldom even neighboring!) longitudinal sectors of the Arctic shows that the different geographic populations of many species reveal rather unsimilar ranges of tolerance to thermic parameters of climate, which in many cases is a result of unsimilar natural history. Yury Chernov showed it by comparison of the curves of dependence of species diversity in many invertebrate taxa on the sum of positive temperatures in Taimyr versus amphi-Beringian sectors: the Beringian fauna is sometimes up to 2 times richer at the same warmth capacity. It is interesting that the most severe windswept snow-free (in winter) habitats in the southern coastal plain of Wrangel Island are dominated by a prostrate race of Salix glauca (S. arctica and $S$. sphenophylla lacking), in Taimyr and the Canadian Arctic archipelago by S. arctica, and at Tiksi Harbour by S. sphenophylla. 
Date: 25 July 2000

From: yurtsev@IK6026.spb.edu (Yurtsev, Boris Alexandrovich)

To: Arve.Elvebakk@ibg.uit.no, reidar.elven@toyen.uio.no, ffdaw@aurora.uaf.edu

Subject: zonation

Organization: Komarov Botanical Institute

Dear Arve:

Thanks for your message of July 17 ! I will continue a bit our discussion of variable zonation of many species in different sectors of the Arctic. If you look through areal maps in later volumes of "Arctic Flora of USSR," you meet many good examples of drastic change of zonal position of a species or even a subspecies in different sectors. Good examples are demonstrated, e.g., by Astragalus alpinus subsp. arcticus [from the west to east]: hypoarctic or even arctic- boreal in the Eastern Fennoscandia (zones E + Boreal) - then low arctic (D+E) - then meta-arctic (zone $\mathrm{C}+\mathrm{D}+\mathrm{E}+$ alpine belt of North Boreal mountains) then high Arctic (zones C $+\mathrm{B}$ ) - again D, etc.

Similar distribution is in Oxytropis sordida. I specially looked through table 9 in Nadya Matveeva's book, "Zonation in vegetation cover of the Arctic," demonstrating the change of the activeness of vascular plant species on a latitudinal gradient in Taimyr, and compared the Taimyr situation with that of Wrangel'sChukotka's. (Wrangel's all cases concern Somnitelnaya Bay area - good zone B, but the Beringian variant). Salix glauca in Taimyr is very rare and only in zone E in Wrangel it is highly active (that is, common + abundant) in zone B (probably a special ecotype of snow-free wind-swept habitats); analogous cases are found in Gastrolychnis angustiflora, Festuca rubra s.str., and Eriophorum callitrix. The following species are common in Wrangel's zone B, but in Taimyr are present (not common) only in zones E+D: Potentilla tikhomirovii, Oxytropis mertensiana, Kobresia myosuroides, Dryas incisa, Pedicularis capitata, Eritrichium sericeum (subsp.), Astragalus tolmaczevii, Potentilla arenosa, Poa glauca, Pedicularis verticillata, Carex maritima, Androsace septentrionalis, Draba arctica, Taraxacum lateritium, Stellaria peduncularis, Salix reticulata, Equisetum variegatum, and Allium schoenophrasum; present in Taimyr zone $\mathrm{C}$ as rare plants, but very common in Wrangel zone B, are Saxifraga platysepala, Armeria maritima, Papaver paucistaminum, Thalictrum alpinum, Draba parvisiliquosa, Carex misandra, Arctagrostis arundinacea, Luzula tundricola, Androsace chamaejasme, Valeriana capitata, Trisetum spicatum, Ranunculus affinis, Polemonium boreale, Astragalus alpinus subsp. arcticum, Artemisia borealis, and many others; present both in C and B zones in Taimyr, but much more common in Wrangel's zone B are Stellaria edwardsii, Astragalus umbellatus, Taraxacum arcticum, Salix reptans, Rhodiola rosea, Poa arctica, Parrya nudicaulis, Nardosmia frigida, Minuartia rubella, Lloydia serotina, Gastrolychnis affinis, Festuca rubra subsp. arctica, F. brachyphylla, Saussurea tilesii, Potentilla hyparctica, Saxifraga nivalis, Polygonum viviparum, Oxyria digyna, Lagotis minor, and many others. The weather station's mean July $+3.6^{\circ} \mathrm{C}$ covers the habitats of the above taxa.

Dr. Olga Rebristaya has given me a number of examples of zonal incongruence in distribution of some plant species in the West Siberian Arctic and in Taimyr. A few principal cases occur: A] In Yamal zones C or B, C (rare), in Taimyr - from E or D to C, B, or even A: Eritrichium villosum, astrolychnis affinis, Papaver lapponicum ssp. jugoricum, and Astragalus umbellatus (mostly arctic to arctic-alpine); B] In Yamal D or D+C+(B), in Taimyr from E to B (or A) zones: Saxifraga nivalis, S. hyperborea, Parrya nudicaulis, Koeleria asiatica, Cassiope tetragona (Yamal D+C; Taimyr E+D!) [Salix nummularia (Y.: $\mathrm{E}+\mathrm{B}, \mathrm{T}$. - the same)]; C] In Yamal E+D+C(+B), in Taimyr - E+D: Comarum palustre, Ranunculus pallasii, Luzula wahlenbergii, Dianthus repens, and Cerastium jenisejens;e D] In Yamal E+D, in Taimyr E or even North forest-tundra: Arctous alpina, Salix myrtilloides, Rubus arcticus, Pyrola minor, Pedicularis lapponica, Linnaea borealis, and Parnassia palustris (mostly boreal to arctic-boreal). The explanations could be different: different history with respect to glaciations/sea transgressions; different 
landscape/habitat conditions, etc., but in all cases it should be reflected in populations' genetics of the plants. I think I would make a pause on this in our discussion. The next item could be the composition and structure of placor/mesic vegetation and soils in "zones" D, C, and B in Chukotka-Wrangel and Taimyr sectors, if you like. 
Date: 18 April 2001

From: yurtsev@IK6026.spb.edu (Yurtsev, Boris Alexandrovich)

To: $\quad$ Steven Talbot $<$ stephen_talbot@fws.gov

Subject: zonation

Organization: Komarov Botanical Institute

Criteria for distinguishing between subzones (S/Z) 2 and 3 (B and C) of the tundra zone (the northern arctic tundra and southern arctic tundra subzones; for the synonyms see below).

1.Lifeforms (growth forms, biomorphs, ecobiomorphs, functional types).

1.1. S/Z 2. Diagnostic plants have woody growth forms: prostrate dwarf-shrubs, including some prostrate shrubs, meta-arctic and arctic-alpine, deciduous or summer-green nondeciduous. Dryas spp., Salix spp.

$\mathrm{S} / \mathrm{Z}$ 3. The same growth form + hemiprostrate evergreen meta-arctic dwarf-shrub (hemichionophilous): Cassiope tetragona. Almost circumpolar with somewhat fluctuating zonal position: absent in Novaya Zemlya and Vaigach, present in Polar Urals; in Taymyr slightly penetrates S/Z 3 only; in East Yakutia - only mainland (absent in Novosibirskiye Islands). In some areas almost mesochionophylous. Both acidic and nonacidic. Most typical of mountains.

\subsection{Herbs (herbaceous growth form).}

$\mathrm{S} / \mathrm{Z}$ 2. Many (nonlong rhizomatous) herbs in $\mathrm{S} / \mathrm{Z} 2$ shift to the larger compact growth form: pulvinate (cushion), caespitose, tussock, especially in open gravelly or rubble sites. This trend strengthens in $S / Z 1$, and there includes bryophytes and lichens. This is an indicator of the harshness of the environment (delimitation of growth). (The plant collections from S/Z 2 are usually recognized by their physiognomy).

$\mathrm{S} / \mathrm{Z}$ 3. This trend is much more weakly expressed in $\mathrm{S} / \mathrm{Z} 3$ - mostly in

higher windswept summits.

\section{Vertical/horizontal structure of plant communities: successional status.}

Given the same conditions, typical of S/Z 2 (in a given sector, at the same lithology and topography, etc.), there are more plant groupings of barrens or with lower plant cover (including frost-boil and dry polygonal tundra), more extensive bare ground, thinner organic layer (arctic turf soils with A1 horizon humus formed because of root decomposition); and early succession stages occur on larger areas compared with $\mathrm{S} / \mathrm{Z}$ 3. In the latter, plant communities with peat and gleyish layers occupy significant areas even on placors.

Note. A) The quantitative values of the above parameters on the boundaries between subzones 2 and 3 vary in different sectors of the Arctic. Do not forget that even in S/Z 1 (high arctic tundras = "polar deserts") one can find plant communities with high projective cover up to continuous hummock tundra, corresponding to the mature succession stage. solutions).

B) In S/Z 2, peaty-gleyish soils are mostly restricted to gullies (depressions with runoff of soil

\section{Floristic affinities of subzones 2 and 3 with subzones 1 and 4.}

In S/Z 2, high-arctic species sensu Tolmachev (= hyperarctic species sensu Matveeva and Chernov), like Puccinellia angustata and allied species, Saxifraga platysepala, Papaver polare, Ranunculus sabinii, Poa abbreviata, high-arctic halophytes (for example, Potentilla pulchella, Braya thorild-wulffii, Poa hartzii, Gastrolychnis triflora), also Festuca hyperborea, F. edlundiae, etc., are usually 
fully represented. For some sectors of S/Z 2, the shift of snowbed species (like Phippsia algida, Saxifraga hyperborea, etc.), adapted to a very short vegetation season, is characteristic on placors. In $\mathrm{S} / \mathrm{Z} 3$, the above species are normally lacking or very rare, but the low-arctic, moderately-arctic ("hemiarctic" sensu Chernov), and hypoarctic species are much more frequent. In $S / Z 2$, many genera or even families that are present in S/Z 3 drop out. However, the set of species with various zonal distributions in different sectors may differ significantly.

4. The set of plant communities in common with neighboring subzones also essentially differs in subzones 2 and 3 . In $S / Z 2$, those especially similar to $S / Z 1$ are plant groupings without woody plants, such as stony barrens Papaveretum dahliani (long-living serial stages), moist moss-forb-cyano-bacteria tundras, etc. The floristic differences distinguishing $S / Z 1$ from $S / Z 2$ are exclusively negative.

Characteristic of $S / Z 3$ is its inclusion of some syntaxa typical of $S / Z 4$. However, in $S / Z 3$ they are usually represented by special variants lacking hypoarctic oligotrophic dwarf-shrubs ("subzone of berryless dwarfshrubs" sensu V.B. (Soczava) and some other hypoarctic and arctic-boreal species, but usually enriched in some arctic-alpine eutrophic species. Among such syntaxa are those typical of placors in S/Z 4 (Cariceta arctisibiricae or C. lugentis, and Eriophorum vaginatum tussock tundra), Carex aquatilis ssp. stans mires, Carex atrofusca fens and some others. (In S/Z 2, grasses with an admixture of a few Cyperaceae usually dominate mires.)

5. Controlling climatic data from weather stations are useful for studying bio-climatic zonation and should be discussed in relation to phytogeographic data. The simplest are mean July temperatures in degrees C. A. Elvebakk gives such mean July temperatures for subzones 1 to 5:

$\mathrm{S} / \mathrm{Z} 1$ 1-2.5 ${ }^{\circ} \mathrm{C}$ (Russian authors: $0.5-2^{\circ} \mathrm{C}$; Edlund et al: $1-3^{\circ} \mathrm{C}$ )

$\mathrm{S} / \mathrm{Z} 2$ $2.5-4^{\circ} \mathrm{C}$

$\mathrm{S} / \mathrm{Z} 3$ $4-6^{\circ} \mathrm{C}$

$\mathrm{S} / \mathrm{Z} 4$ $6-8^{\circ} \mathrm{C}$

$\mathrm{S} / \mathrm{Z} 5$

$$
8-10^{\circ} \mathrm{C}
$$

Other thermic parameters are the sum of positive mean monthly temperatures or degrees (above zero) $\mathrm{x}$ day temperatures, which include positive June and August temperatures. But a warmer June has greater significance for arctic plants than a warmer August, when the common tundra plants turn yellow or red. Thus, the Ayon weather station with mean July temperatures of $4.3^{\circ} \mathrm{C}$ and mean June temperatures of about $2^{\circ} \mathrm{C}$, belongs to the northern hypoarctic (= typical) tundra subzone with placor Eriophorum tussock, Betula exilis, Rubus chamaemorus, etc. So, some thermic parameters may overlap in marginal areas.

All the above criteria should be checked on regional data for each sector separately. 


\title{
FOURTH INTERNATIONAL \\ CIRCUMPOLAR ARCTIC VEGETATION MAPPING WORKSHOP
}

\author{
Moscow, Russia \\ April 10-13, 2001
}

\author{
AGENDA \\ Monday April 9 \\ Arrival, check into hotel \\ Tuesday April 10 \\ Note: Posters should be up for display during the entire length of the workshop. \\ 8:00 Breakfast at hotel \\ 9:00-9:30 Welcome - Evgeny Melnikov \\ 9:30-10:00 Welcome, history, progress, and future of the CAVM - D.A. Walker \\ 10:00-10:30 Canadian Arctic vegetation and ecosystem properties - W.A. Gould, \\ M.K. Raynolds, D.A. Walker, and S. Edlund \\ 10:30-11:00 Synthesis of Alaska and Canada - M.K. Raynolds, D.A. Walker, \\ C.J. Markon, and W.A. Gould \\ 11:00-11:30 Beverage Break \\ 11:30-12:30 On the way to an integrated vegetation map of Greenland - Fred J.A. Daniels and Maike \\ Wilhelm \\ 1:00-2:00 Lunch \\ 2:00-3:00 The situation of Iceland in the system used in the CAVM mapping - Eythor Einarsson \\ and Gudmundur Gudjonsson \\ 3:00-3:30 Percent cover of lakes - Galina V. Ananjeva (Malkova), Olga. E. Ponomarjeva \\ 3:30-4:00 Landscape map of the Russian Arctic - Dmitriy S. Drozdov, Galina V. \\ Ananjeva (Malkova) \\ 4:00-4:30 Vegetation map of European Russia - Sergei S. Kholod and Galina V. \\ Ananjeva \\ 4:30-5:00 Vegetation map of West Siberia, Taimyr, and Yakutia - Natalia Moskalenko \\ 5:00-5:30 Peculiarities of the legend of Chukotka vegetation map - Adrian Katenin \\ 5:30-6:00 Dinner \\ 7:00 Cultural event \\ Wednesday, April 11 \\ 8:00 Breakfast at hotel \\ 9:00-9:30 Vegetation map and reindeer forage of the Taimyr national district; \\ 1 :500,000 scale 1974-1976, Raisa P. Schelkunova \\ 9:30-10:00 Some questions of mapping circumpolar arctic vegetation (CAVM) \\ Boris A. Yurtsev
}


10:00-10:30 Progress on the vegetation legend - Sergei Kholod, Adrian Katenin, Irina Safronova, Boris Yurtsev

10:30-11:00 Principles of design for a map (legend, color, hachure) Irina N. Safronova

11:00-11-30 Beverage break

11:30-12:00 Ideas regarding the development of an Arctic vegetation map showing dominant Braun-Blanquet Syntaxa - Fred Daniels

12:00-1:00 Plan for publication of the map - Steve Talbot

1:00-2:00 Lunch

2:00-3:00 Working groups: Discussion of design for 1:7.5M map

3:00-3:30 Beverage break

3:30-5:30 Plenary session: Working group reports, synthesis of ideas

5:30 Adjourn

7:00-9:00 Banquet

Thursday, $\quad$ April 12

8:00 Breakfast at hotel

9:30-10:00 Discussion of map product

10:00-11:00 Plenary session: Discussion of bioclimatic zones

11:00-11:30 Beverage break

11:30-12:30 Plenary Session: Discussion of plant functional type tables

12:30-2:00 Lunch

2:00-3:30 Working groups: Plant functional type tables by region

3:30-4:00 Beverage break

4:00-6:00 Plenary session: Plant functional type tables

6:00 Adjourn

Friday, April 13

8:00

Breakfast at hotel

9:30-11:00 Discussion of map production schedule

11:00-12:30 Discussion of abstract volume publication

12:30-1:30 Lunch

1:30-4:00 Slide show - Canadian transect by Skip Walker, Russian slides by Adrian Katenin, Sergei Kholod, and Irina Safronova

4:00 Adjourn

Departure 


\section{MOSCOW CAVM WORKSHOP PARTICIPANTS}

Galina V. Ananjeva (Malkova)

Earth Cryosphere Institute

30/6, Vavilov Str.

Moscow, 119991, Russia

TELEPHONE: 0951359871

FAX: 0951356582

E-MAIL: emelnikov@mtu-net.ru

Fred J.A. Daniels

Institute of Plant Ecology

Hindenburgplatz 55

Muenster 48143, Germany

TELEPHONE: 492518323835

FAX: 492518321705

E-MAIL: daniels@uni-muenster.de

Dmitriy S. Drozdov

Earth Cryosphere Institute SB RAS

30/6 Vavilov Str.

Moscow, 119991, Russia

TELEPHONE: 0951359871

FAX: 0951356582

E-MAIL: emelnikov@mtu-net.ru

Eythor Einarsson

Icelandic Institute of Natural History

Hilemmur 3

Box 5320

Reykjavik, IS-125 Iceland

TELEPHONE: 3545900500

FAX: 3545900595

E-MAIL: eythor@ni.is
Arve Elvebakk

University of Tromso

Dept. of Biology

Tromso N-9037, Norway

TELEPHONE: 4777644436

FAX: 4777646333

E-MAIL: arve@ibg.uit.no

William A. Gould

International Inst. for Tropical Forestry

PO Box 25000

San Juan, Puerto Rico 00928-5000

TELEPHONE: 7877665335

FAX: 7877666302

E-MAIL: IITF COOP@upr.edu

Adrian Evgenievich Katenin

Komarov Botanical Institute RAS

Prof. Popov Str. 2

St. Petersburg 197376 Russia

TELEPHONE: 7095 234-22-73

FAX: 70952344512

E-MAIL: katenin@IK6026.spb.edu

Sergei Serafimovich Kholod

Komarov Botanical Institute RAS

Prof. Popov Str. 2

St. Petersburg 197376 Russia

TELEPHONE: 7095 234-22-73

FAX: 70952344512

Dmitriy E. Konyushkov

Dokuchaev Soil Institute

Moscow, Russia

E-MAIL: dkon@agro.geonet.ru 
Yuri V. Korostelev

Earth Cryosphere Institute SB RAS

30/6 Vavilov Str.

Moscow, 119991, Russia

TELEPHONE: 0951359871

E-MAIL: emelnikov@mtu-net.ru

Victor N. Krainov

Moscow State University

Moscow, Russia

E-MAIL: vkrainov@hotmail.com

Valeriy V. Kusovkin

OAO Mosgiprotans

FAX: (095) 742-47-12

Marina O. Leibman

Earth Cryosphere Institute

30/6 Vavilov Str.

Moscow, 119991, Russia

TELEPHONE: 0951359871

FAX: 0951356582

E-MAIL: mleibman@online.ru

Nadezda V. Matveyeva

Komarov Botanical Institute RAS

Prof. Popov Str. 2

St. Petersburg 197376 Russia

TELEPHONE: 70952342273

FAX: 70952344512

E-MAIL: nadyam@nveget.bin.ras.spb.ru

Evgeny S. Melnikov

Earth Cryosphere Institute SB RAS

30/6 Vavilov Str.

Moscow, 119991, Russia

TELEPHONE: 0951359871

FAX: 0951356582

E-MAIL: emelnikov@mtu-net.ru
Natalia G. Moskalenko

Earth Cryosphere Institute SB RAS

30/6 Vavilov Str.

Moscow, 119991, Russia

TELEPHONE: 0951359871

FAX: 0951356582

E-MAIL: emelnikov@mtu-net.ru

Galina N. Ogyreeva

Moscow State University

Moscow, Russia

E-MAIL: ogur@biogeo.geogr.msu.su

Olga E. Ponomaryeva

Earth Cryosphere Institute SB RAS

30/6 Vavilov Str.

Moscow, 119991, Russia

TELEPHONE: 0951359871

FAX: 0951356582

E-MAIL: emelnikov@,mtu-net.ru

Martha K. Raynolds

Institute of Arctic Biology

University of Alaska Fairbanks

P.O. Box 757000

Fairbanks, AK 99775-7000

TELEPHONE: 9074742459

FAX: 9074747666

E-MAIL: fnmkr@uaf.edu

Irina N. Safronova

Komarov Botanical Institute

Prof. Popov Str. 2

St. Petersburg 197376 Russia

TELEPHONE: 78122341792

FAX: 78122344512

E-MAIL: irinasaf@IS1189.spb.edu 
Yuri A. Sagaydachniy

Earth Cryosphere Institute SB RAS

30/6 Vavilov Str.

Moscow, 119991, Russia

TELEPHONE: (095) 1359871

FAX: 0951356582

E-MAIL: emelnikov@mtu-net.ru

Raisa P. Schelkunova

Severo-Zapadnoe Lesoystroitelnoe predpreitie

E-MAIL: nwsfme@mail.admiral.ru

Olga Sumina

St. Petersburg State University

St. Petersburg, Russia

TELEPHONE: 078125521364

FAX: 078123281472

E-MAIL: osumina@OS3773.spb.edu;

osumina@gs.bio.pu.ru

Ludmila A. Syhodolscai

Earth Cryosphere Institute SB RAS

30/6 Vavilov Str.

Moscow, 119991, Russia

TELEPHONE: 0951359871

FAX: 0951356582

E-MAIL: kriozem@online.ru

Stephen S. Talbot

U.S. Fish and Wildlife

1101 East Tudor Dr.

Anchorage, AK 99503

TELEPHONE: 9077863381

E-MAIL: Stephen_Talbot@fws.gov

Valeria A. Volgina

Earth Cryosphere Institute SB RAS

30/6 Vavilov Str.

Moscow, 119991, Russia

TELEPHONE: (095) 1359871

FAX: (095) 1356582

E-MAIL: volgina@yahoo.com
Donald (Skip) Walker

Institute of Arctic Biology

University of Alaska

P.O. Box 757000

Fairbanks, AK 99775-7000

TELEPHONE: 9074742460

FAX: 9074747666

E-MAIL: fnmkr@uaf.edu

Maike Wilhelm

Institute of Plant Ecology

Hindenburgplatz 55

Muenster 48143 Germany

TELEPHONE: 492518321740

FAX: 492518321705

E-MAIL: wilhema@uni-muenster.de

Boris A. Yurtsev

Komarov Botanical Institute

Prof. Popov Str. 2

St. Petersburg 197376 Russia

TELEPHONE: 78122341792

FAX: 7812 234-45-12

E-MAIL: yurtsev@IK6026.spb.edu

Nina A. Zaytseva

Presidium

Russian Academy of Sciences

Moscow, Russia

E-MAIL:ninaz@orc.ru 